UDK 902

ISSN 1330-0644

Vol. 38/2

ZAGREB, 2021.
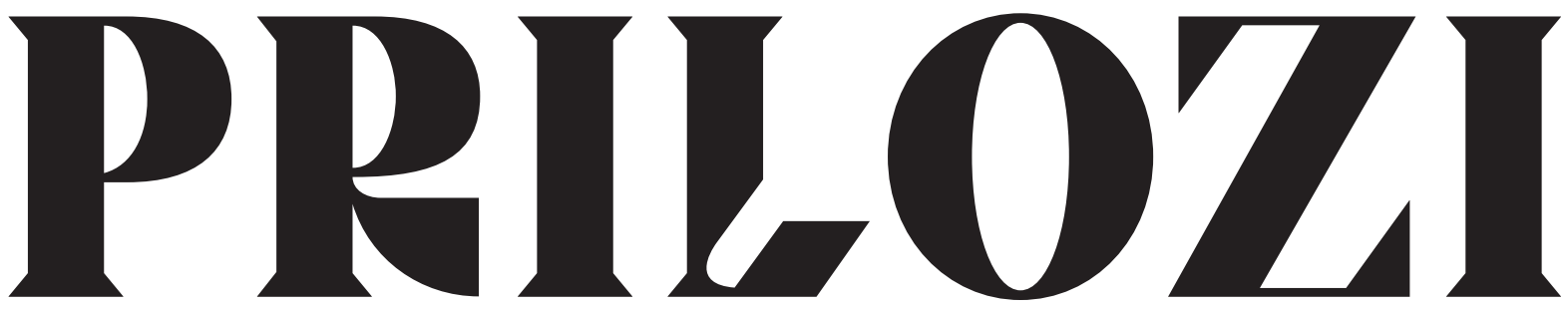

Instituta za arheologiju u Zagrebu 
Pril. Inst. arheol. Zagrebu, 38/2/2021

Str./Pages 1-218, Zagreb, 2021.

E-izdanja. Publikacija je dostupna u digitalnom obliku i otvorenom pristupu na

https://hrcak.srce.hr/prilozi-iaz

E-edition. The publication is available in digital and open access form at

https://hrcak.srce.hr/prilozi-iaz?lang=en

Ovaj rad licenciran je pod Creative Commons Attribution By 4.0 međunarodnom licencom / This work is licenced under a Creative Commons Attribution By 4.0 International Licence
Izdavač/Publisher

INSTITUT ZA ARHEOLOGIJU

INSTITUTE OF ARCHAEOLOGY

Adresa uredništva/Address of the editor's office Institut za arheologiju/Institute of archaeology

HR-10000 Zagreb, Jurjevska ulica 15

Hrvatska/Croatia

Telefon/Phone ++385/(0)1 6150250

Fax ++385(0)1 6055806

e-mail: urednistvo.prilozi@iarh.hr

http://www.iarh.hr

Glavni i odgovorni urednik/Editor in chief

Marko DIZDAR

Tehnički urednici/ Technical editors

Marko DIZDAR

Katarina BOTIĆ

Uredništvo/Editorial board

Marko DIZDAR, Snježana VRDOLJAK, Viktória KISS (Budapest, HUN) (prapovijest/Prehistory), Goranka LIPOVAC VRKLJAN, Ivan RADMAN-LIVAJA (antika/ Antiquities), Tajana SEKELJ IVANČAN, Katarina Katja PREDOVNIK (Ljubljana, SLO), Natascha MEHLER (Wien, AUT), Tatjana TKALČEC (srednji vijek i novi vijek/ Middle Ages and Modern era), Predrag NOVAKOVIĆ (Ljubljana, SLO) (metodologija/Methodology)

Izdavački savjet/Editorial advisory board

Dunja GLOGOVIĆ (Zagreb), Ivor KARAVANIĆ (Zagreb), Laszlo KÓVACS (Budapest, HUN), Kornelija MINICHREITER (Zagreb), Aleksandar RUTTKAY (Nitra, SK), Ivančica SCHRUNK (Minneapolis, USA), Željko TOMIČıĆ (Zagreb), Ante UGLEŠıĆ (Zadar)

Prijevod na engleski/English translation

Inga VILOGORAC BRČIĆ, Kristina DESKAR, Igor KULENOVIĆ, Irena RADIĆ ROSSI, Saba RISALUDDIN

Lektura/Language editor

Ivana MAJER, Marko DIZDAR (hrvatski jezik/Croatian)

Marko MARAS, Kristina DESKAR (engleski jezik/English)

Korektura/Proofreads

Katarina BOTIĆ

Grafičko oblikovanje/Graphic design

Umjetnička organizacija OAZA

Računalni slog/Layout

Hrvoje JAMBREK

Tisak/Printed by

Sveučilišna tiskara d.o.o., Zagreb

Naklada/Issued

400 primjeraka/400 copies

Prilozi Instituta za arheologiju u Zagrebu uključeni su u sljedeće indekse/

Prilozi Instituta za arheologiju u Zagrebu are included in following indices:

DYABOLA - Sachkatalog der Bibliothek - Römisch-Germanische Kommission des Deutschen Archaeologischen Instituts, Frankfurt a. Main

Clarivate Analytics services - Web of Science Core Collection

CNRS/INIST - Centre National de la Recherche Scientifi que/L'Institut de I'Information Scientifi que et Technique, Vandoeuvre-lès-Nancy

EBSCO - Information servises, Ipswich

ERIH - European Reference Index for the Humanities, European Science Fundation, Strasbourg

SciVerse Scopus - Elsevier, Amsterdam 
Sadržaj

\section{Izvorni znanstveni radovi}

5

\author{
IGOR KULENOVIĆ \\ ŠIME VRKIĆ \\ VEDRANA GLAVAS̆
}

NEDA KULENOVIĆ OCELIĆ

Vidljivost kao element strukturiranja krajolika Primjer višeperiodnoga arheološkog lokaliteta Bojnik na ušću rijeke Zrmanje

\section{ADNAN BUSULADŽIĆ}

Antičke kopče iz muzejskih zbirki u Bosni i Hercegovini (izbor nalaza)

JURAJ BELAJ

FILOMENA SIROVICA

ŽELJKA BEDIĆ

Crkva Uznesenja Blažene Djevice Marije u Gori kraj Petrinje i faze ukopavanja grobova na prostoru sakristije

115 MARIN EMIĆ

Kasnosrednjovjekovna plemićka kurija kraj Orahovice - Uvod u razumijevanje kasnosrednjovjekovne kurije u kontinentalnoj Hrvatskoj

157 INES ŠELENDIĆ IRENA RADIĆ ROSSI

Novi stakleni nalazi iz tereta broda Gagliana grossa potonuloga kod otočića Gnalića 1583.

\section{Contents}

\section{Original scientific papers}

\author{
IGOR KULENOVIĆ \\ ŠIME VRKIĆ \\ VEDRANA GLAVA ̌ \\ NEDA KULENOVIĆ OCELIĆ \\ Visibility as an element of landscape structuring- \\ An example of multi-period archaeological site \\ Bojnik at the mouth of Zrmanja river
}

\section{ADNAN BUSULADŽIĆ}

Buckles of Antiquity from the Museum Collections of Bosnia and Herzegovina (a selection)

\section{JURAJ BELAJ \\ FILOMENA SIROVICA \\ ŽELJKA BEDIĆ}

Church of the Assumption of the Blessed Virgin Mary in Gora near Petrinja and the phases of the burials in the area of sacristy

\section{MARIN EMIĆ}

Late Medieval Manor House near Orahovica Introduction into the Understanding of a Late Medieval Manor House in Continental Croatia

\section{INES ŠELENDIĆ \\ IRENA RADIĆ ROSSI}

New glass finds from the cargo of the ship Gagliana grossa, sunk near the islet of Gnalić in 1583 


\section{Prethodno priopćenje}

199 INGA VILOGORAC BRČIĆ

LAURENT BRICAULT

Mithras in Teutoburgium

\section{Prikaz}

DOMAGOJ TONČINIĆ

Studia honoraria archaeologica. Zbornik radova $u$ prigodi 65. rođendana prof. dr. sc. Mirjane Sanader, Tončinić D., Kaić I., Matijević V., Vukov M. (eds.)

\section{Preliminary report}

INGA VILOGORAC BRČIĆ

LAURENT BRICAULT

Mitra u Teutoburgiju

\section{Book review}

DOMAGOJ TONČINIĆ

Studia honoraria archaeologica. Special volume on the occasion of the 65th birthday of prof. $d r$. Mirjana Sanader, Tončinić D., Kaić I., Matijević V., Vukov M. (eds.) 


\title{
Novi stakleni nalazi iz tereta broda Gagliana grossa potonuloga kod otočića Gnalića 1583.
}

\section{New glass finds from the cargo of the ship Gagliana grossa, sunk near the islet of Gnalic in 1583}

\author{
Izvorni znanstveni rad \\ Novovjekovna arheologija \\ Original scientific paper \\ Early Modern archaeology \\ UDK/UDC 904:748(210.7 Gnalić)(497.5)"1583" \\ Primljeno/Received: 12. 03. 2021. \\ Prihvaćeno/Accepted: 17. 06. 2021.
}

\author{
INES ŠELENDIĆ \\ Arheološki muzej Zadar \\ Trg opatice Čike 1 \\ HR-23000 Zadar \\ ineselendic@gmail.com \\ IRENA RADIĆ ROSSI \\ Odjel za arheologiju \\ Sveučilište u Zadru \\ Obala kralja Petra Krešimira IV \\ HR-23000 Zadar \\ irradic@unizd.hr
}

\begin{abstract}
Mletački trgovački brod natovaren raznovrsnim teretom potonuo je kod otočića Gnalića krajem listopada ili početkom studenoga 1583. Brodski se teret sastojao od sirovina, poluproizvoda i gotovih proizvoda namijenjenih carigradskome tržištu i sultanovome dvoru, što je višestruko potvrđeno arheološkim i povijesnim istraživanjima. Među gotovim proizvodima posebno se ističe velika količina staklenih predmeta podijeljenih u dvije glavne skupine: šuplje i ravno staklo. Prva skupina obuhvaća raznolike oblike stolnoga posuđa, spremnika za hranu i piće i staklenih perli, dok se u drugoj nalaze prozorska stakla i stakla za ogledala. Nakon službenoga otkrića nalazišta 1967. godine, organizirano je pet zaštitnih istraživačkih kampanja s ciljem pravovremenoga spašavanja najvrjednijih nalaza. Nakon 1973. aktivnosti zaštitne prirode kratkotrajno su obnovljene 1996., a sustavno istraživanje, primjereno značenju i stanju nalazišta, započelo je tek 2012. godine. Prve sistematizacije staklene građe izradili su Sofija Petricioli i Astone Gasparetto. U okviru međunarodnoga projekta The Heritage of the Serenissima 2004. godine Irena Lazar, Hugh Willmott i Caroline Jackson sustavno su obradili staklene nalaze. Tijekom istraživanja 2012. - 2020., usmjerenih poglavito na otkrivanje i dokumentiranje brodske konstrukcije, izvađene su tisuće ulomaka staklenih predmeta. lako je u većini slučajeva riječ o primjercima stolnoga posuđa i ravnoga stakla, koji se u potpunosti uklapaju u do sada predloženu tipologiju staklenih nalaza iz brodskoga tereta, u nekim slučajevima primjećuju se i određene razlike. U radu su predstavljeni novi nalazi koji dopunjuju dosadašnje spoznaje ili ukazuju na mogućnost različite interpretacije ranijih nalaza.
\end{abstract}

Ključne riječi: staklo, brod, brodolom, Gnalić, Gagliana grossa, kasna renesansa, pomorska trgovina

\begin{abstract}
A Venetian merchant ship loaded with various cargo sank off the islet of Gnalić in late October or early November 1583. As confirmed by archaeological and historical research, the ship's cargo consisted of raw materials, semi-finished and finished products, intended for the Constantinople market and the sultan's court. Among the finished products, a large amount of glass objects stands out. It is divided into two main groups: hollow and flat glass. The first group includes various forms of tableware, food and beverage containers and glass beads, while the second group includes window panes and mirror glasses. After the official discovery of the site in 1967, five rescue research campaigns were organized with the aim of salvaging the most valuable finds. After 1973, rescue research was briefly renewed in 1996. The systematic research, appropriate to the significance and condition of the site, begun just in 2012. The first systematization of glass was made by Sofia Petricioli and Astone Gasparetto. In 2004, Irena Lazar, Hugh Willmott and Caroline Jackson systematically processed the glass finds, in the framework of the international project The Heritage of the Serenissima. During the 2012-2020 research, focused mainly on the detection and documentation of ship hull, thousands of fragments of glass objects were recovered. Although in most cases these are examples of tableware and flat glass, which completely fit into the hitherto proposed typology of glass finds from the ship's cargo, in some cases certain differences were noticed. This paper presents new finds that supplement previous knowledge or indicate the possibility of different interpretation of previous finds.
\end{abstract}

Keywords: glass, ship, shipwreck, Gnalić, Gagliana grossa, Late Renaissance, maritime trade 


\section{UVODNE NAPOMENE}

Otočić Gnalić ili Kamenčić, površine oko $4700 \mathrm{~m}^{2}$, nalazi se u zadarskome dijelu sjevernodalmatinskoga arhipelaga i pripada pašmanskoj otočnoj skupini. Leži između Srednjega kanala koji odvaja Pašman od Kornata i Dugoga otoka te Pašmanskoga kanala koji odvaja otok Pašman od kopna. Pašmanski kanal ima istaknuto značenje jer se u njemu odvija intenzivan pomorski promet prema Zadarskome kanalu. Njegovo značenje odražava se i na širem prostoru jer služi kao spona između otoka i gradskih kopnenih naselja, Zadra i Biograda (Magaš 2006: 10-11) (sl. 1).

\section{INTRODUCTORY REMARKS}

The islet of Gnalić or Kamenčić, with an area of about $4700 \mathrm{~m}^{2}$, is located in the Zadar area of the northern Dalmatian islands, and belongs to the Pašman archipelago. It lies between the Middle Channel that separates Pašman from Kornati and Dugi otok, and the Pašman Channel that separates the island of Pašman from the mainland. The Pašman Channel has a prominent significance, because it is used for intensive maritime traffic towards the Zadar Channel. Its significance is also reflected in the wider area, because it serves as a link between the islands and the city's mainland settlements Zadar and Biograd na Moru (Magaš 2006: 10-11) (Fig. 1).

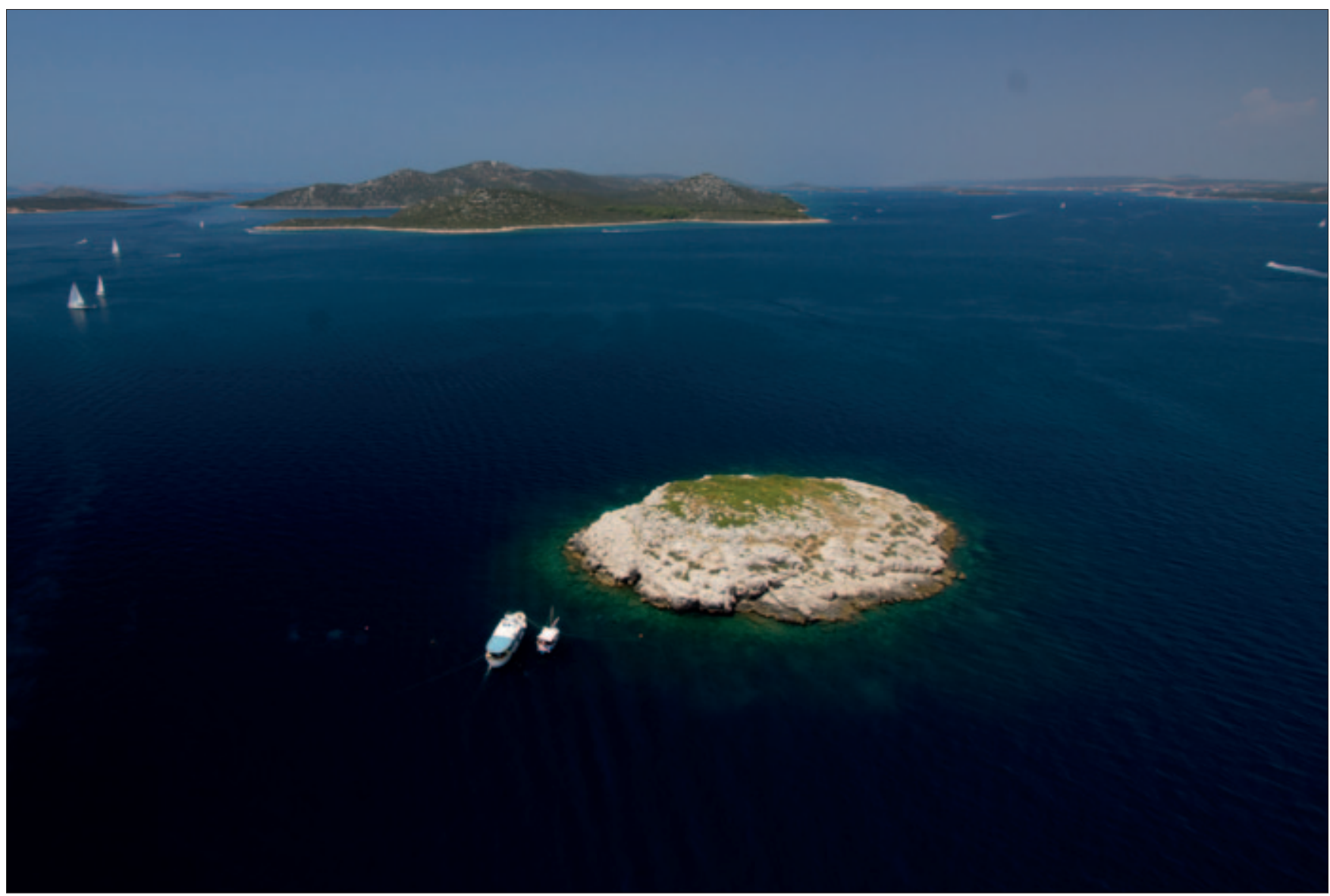

SI. 1 Položaj otočića Gnalića u odnosu na otok Pašman i južni ulaz u Pašmanski kanal (snimio: E. Šilić)

Fig. 1 The position of the islet of Gnalić in relation to the island of Pašman and the southern entrance to the Pašman Channel (photo by: E. Šilić)

Ime Gnalić izvedeno je od imena krajnjega jugoistočnog dijela otoka Pašmana zvanoga Punta Gnala. To su ime otočiću pridijelili stanovnici nedalekoga otoka Murtera koji su Pašmanu pristupali upravo s te strane.' U kartografskome izvoru iz 1824. otočić se spominje pod imenom Sco(glio) Kamicich (Skračić 2006: 262), a ime Kamenčić ili Kamenčić Gornji i danas koriste stanovnici otoka Pašmana. Otočić se nalazi na administrativnome području općine Tkon, a uz Biograd na Moru vezan je činjenicom da su predmeti izvađeni iz njegovoga podmorja pohranjeni i dijelom izloženi u biogradskome Zavičajnom muzeju (Božulić 2003).

1 Usmeni podatak V. Skračić.
The name Gnalić derives from the name of the extreme south-eastern part of the island of Pašman, called the Gnal Promontory. This name was given to the island by the inhabitants of the nearby island of Murter, who approached Pašman from that side. I In a cartographic source from 1824, the islet is mentioned under the name Sco(glio) Kamicich (Skračić 2006: 262) and the name Kamenčić or Kamenčić Gornji (eng. Upper) is still used by the inhabitants of the island of Pašman. The islet is located in the administrative area of the municipality of Tkon, and is connected to Biograd na Moru by the fact that the objects recovered from the

Personal communication V. Skračić. 
S jugoistočne strane otočića Gnalića šezdesetih godina prošloga stoljeća, na dubini od tridesetak metara, pronađeno je neizmjerno vrijedno arheološko nalazište potopljenoga ranonovovjekovnog broda s brojnim predmetima iz brodske opreme i tereta razasutim po površini morskoga dna (Radić Rossi et al. 2013: 67) (sl. 2).

O postojanju nalazišta stručnjaci su obaviješteni u rujnu 1967., nakon višegodišnje devastacije. Prve zaštitne akcije započele su iste godine pod vodstvom Ive Petriciolija i Ksenije Radulić. Istraživanje se nastavilo i sljedeće godine, a nakon trogodišnjega prekida nakratko je obnovljeno 1972. i 1973. godine. Stručnu pomoć pružili su Sofija Petricioli i Božidar Vilhar zaduženi za prihvat i konzervatorsku obradu izvađenih nalaza (Petricioli 1973; 1974). Cilj prvih istraživačkih kampanja nearby underwater site are stored and partly exhibited in the Local Heritage Museum of Biograd na Moru (Božulić 2003).

In the 1960s, on the south-eastern side of the islet of Gnalić, at a depth of thirty meters, an immensely valuable post-mediaeval shipwreck site was found, with numerous items from ship equipment and cargo scattered on the seabed (Radić Rossi et al. 2013: 67) (Fig. 2).

In September 1967, after several years of unauthorized exploitation, the experts were informed about the existence of the site. The first rescue research began in the same year, under the leadership of Ivo Petricioli and Ksenija Radulić. The research continued the following year, and after a three-year break, it was briefly renewed in 1972 and 1973.

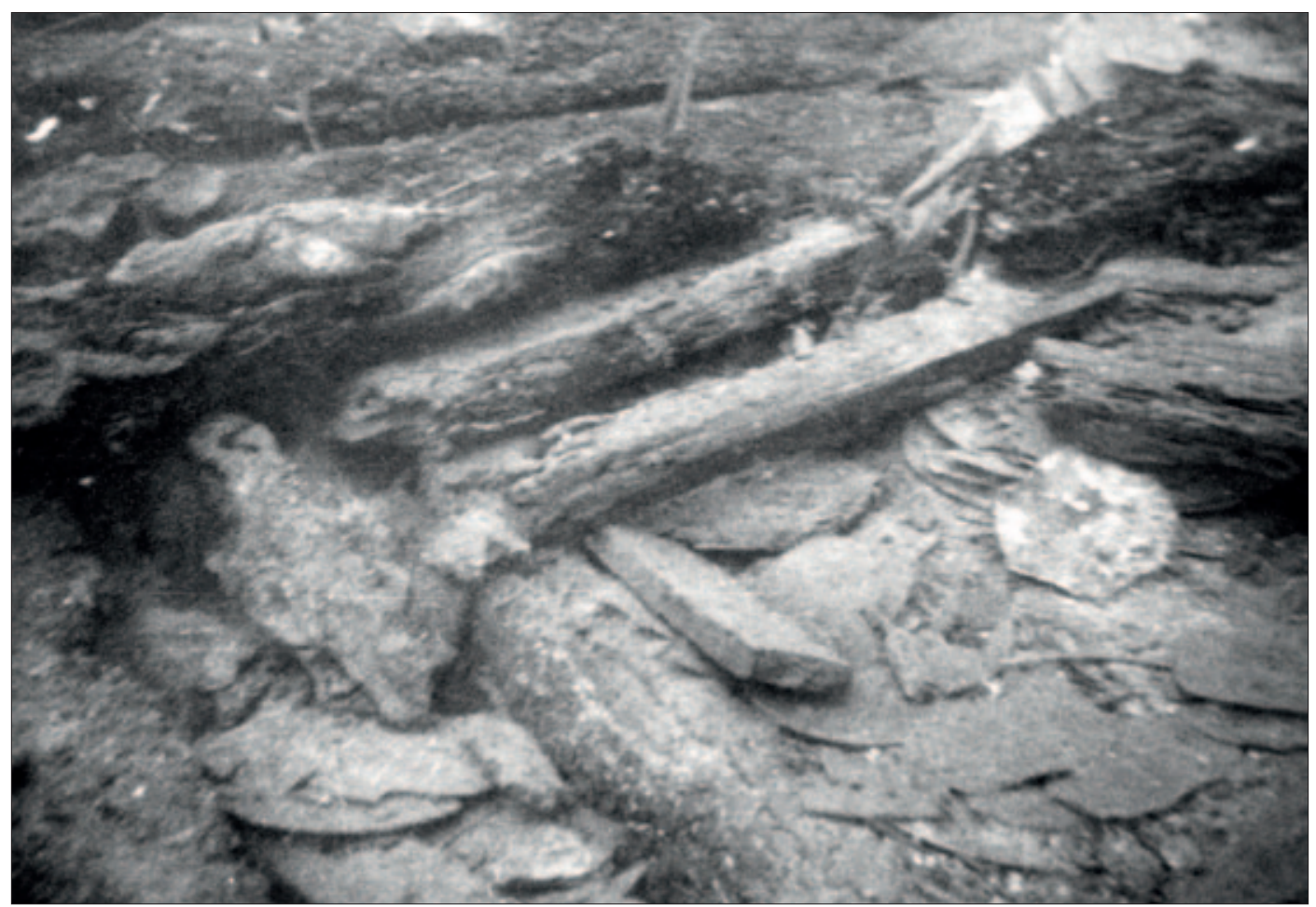

SI. 2 Nalazi ravnoga stakla među drvenim elementima brodske konstrukcije, 1967. (snimio: D. Balenović)

Fig. 2 Finds of flat glass among wooden elements of a ship's structure, 1967 (photo by: D. Balenović)

bio je uklanjanje lako dostupnih predmeta s morskoga dna kako bi se spriječila daljnja devastacija nalazišta, a dugoročni prestanak istraživanja bio je uzrokovan nepostojanjem odgovarajućih uvjeta za organizaciju i realizaciju tako zahtjevnoga projekta (Radić Rossi et al. 2013: 68-70).

Prema riječima ronilaca koji su sudjelovali u prvim zaštitnim akcijama, ${ }^{2}$ na površini morskoga dna ležala su razasuta brojna prozorska stakla, a iz prvih objava rezultata istraživanja vidljivo je kako su već u samome početku izvađene i velike količine raznolikoga staklenog stolnog posuđa. Nalaze iz te skupine Sofija Petricioli prva je predstavila domaćoj i inozemnoj javnosti, a Robert Brill proveo je preliminarne arheometrijske analize (Petricioli 1970; 1973; Brill 1973: 93). Talijanski povjesničar umjetnosti Astone Gasparetto, inspiriran izložbom o brodolomu kod Gnalića, pokušao je u Državnome arhivu u Veneciji identificirati po-

2 Usmeni podaci D. Martinović i J. Domančić.
Expert assistance was provided by Sofija Petricioli and Božidar Vilhar, in charge of receiving and conserving the excavated finds (Petricioli 1973; 1974). The goal of the first research campaigns was to remove easily accessible objects from the seabed, in order to prevent further devastation of the site. The long-term break was caused by the lack of appropriate conditions for organizing and implementing such a demanding project (Radić Rossi et al. 2013: 68-70).

According to the divers who took part in the first rescue campaigns, ${ }^{2}$ numerous window panes were scattered in the surface layer. The first publications of the research results showed that large quantities of various glass tableware were recovered from the very beginning. Sofia Petricioli was the first to present the glass finds to the domestic and foreign public, and Robert Brill conducted preliminary archaeometric analyses (Petricioli 1970; 1973; Brill 1973: 93). The Italian art historian Astone Gasparetto, inspired by an exhibition on the shipwreck of Gnalić, tried to identify the sunken ship

2 Personal communications D. Martinović and J. Domančić 
tonuli brod (Gasparetto 1973: 79). ${ }^{3}$ Godine 1973. objavio je rezultate svojih arhivskih istraživanja, a tri godine kasnije dodatno je osnažio svoje pretpostavke da je riječ o brodu Gagliana grossa i stručnoj javnosti predstavio do tada poznate staklene nalaze (Gasparetto 1973; 1976). ${ }^{4}$ lako je u njegovo doba identifikacija broda ostala na razini pretpostavke, ona je višestruko potvrđena arhivskim istraživanjima koja se provode tijekom posljednjih nekoliko godina (Radić Rossi, Nicolardi 2019). in the State Archives in Venice (Gasparetto, 1973: 79). ${ }^{3}$ In 1973 , he published the results of his archival research, and three years later he further strengthened his identification of the ship as the Gagliana grossa, and presented the glass finds to the professional public (Gasparetto 1973; 1976). ${ }^{4}$ Although in his time the identification of the ship remained at the level of assumption, it has since been confirmed by archival research conducted over the past few years (Radić Rossi, Nicolardi 2019).

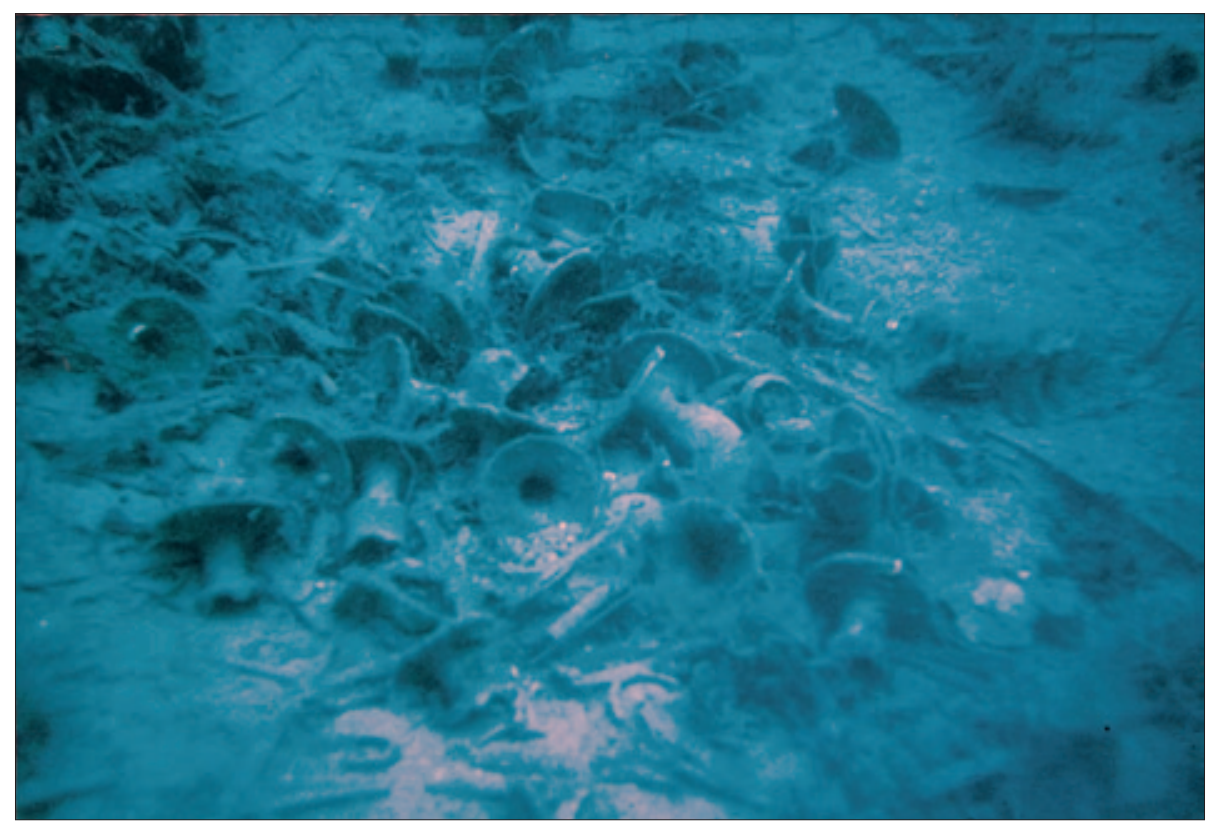

SI. 3 Ulomci stolnoga staklenog posuđa na 'polju stakla', 1996. (snimio: Z. Brusić) Fig. 3 Fragments of tableware in a 'field of glass', 1996 (photo by: Z. Brusić)

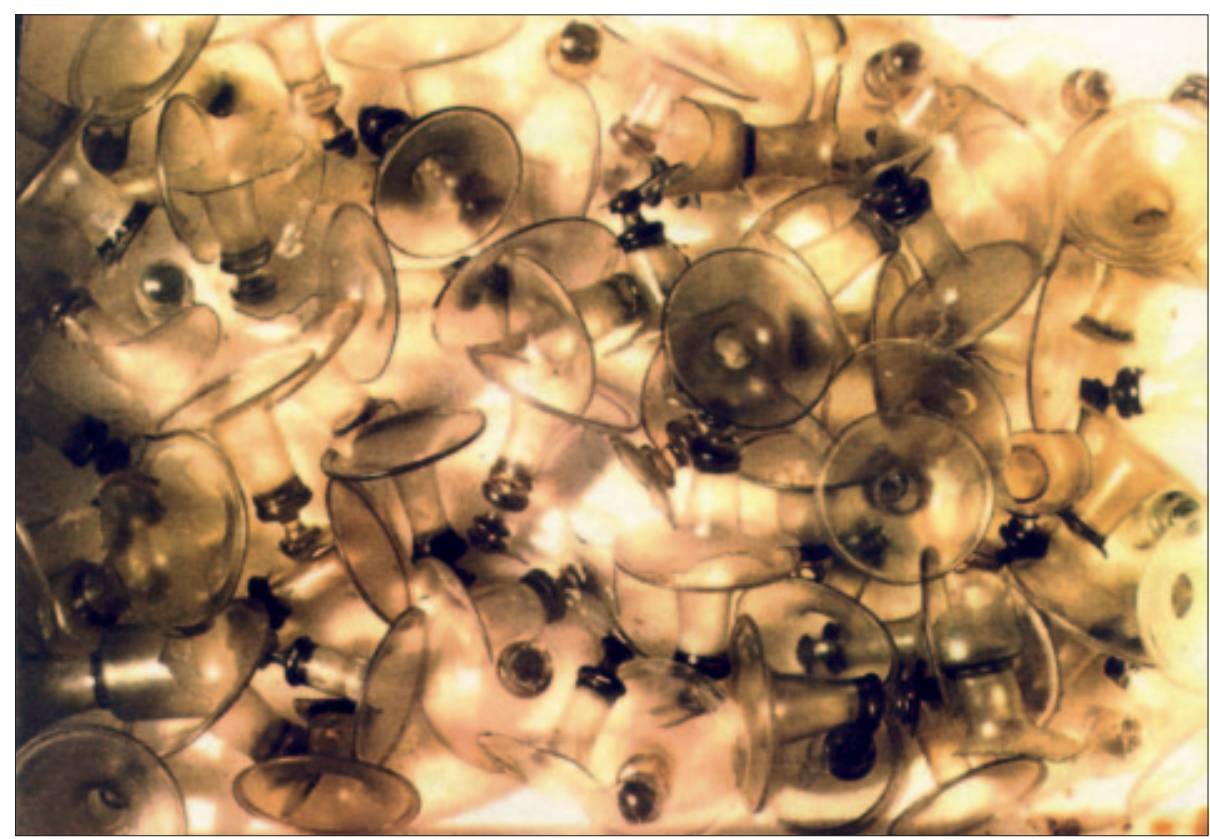

SI. 4 Ulomci stolnoga staklenog posuđa nakon vađenja iz mora, 1996. (snimio: Z. Brusić) Fig. 4 Fragments of tableware after extraction from the sea, 1996 (photo by: Z. Brusić)

3 Godine 1970. i 1971. nalazi s brodoloma potonuloga kod otočića Gnalića bili su predstavljeni na izložbama u Zadru, Zagrebu, Ljubljani i Beogradu pod nazivom „Blago s morskog dna. Izložba predmeta s potopljenog broda iz kraja 16. stoljeća" (Petricioli 1969; 1971; Munk, Radulić 1971).

4 Gasparettov rad iz 1973. preveden je na hrvatski i objavljen 1977. godine (vidi: Gasparetto 1977).
3 In 1970 and 1971, the finds from the shipwreck of Gnalić were presented at the exhibitions in Zadar, Zagreb, Ljubljana and Belgrade, under the title "Treasures from the seabed. Exhibition of objects from a sunken ship from the end of the $16^{\text {th }}$ century" (Petricioli 1969; 1971; Munk, Radulić 1971).

4 Gasparetto's work from 1973 was translated into Croatian and published in 1977 (see: Gasparetto 1977). 
Godine 1996. istraživanje je nakratko obnovljeno na inicijativu Zdenka Brusića (Brusić 1996) koji je aktivno sudjelovao u prvoj zaštitnoj akciji trideset godina ranije. Površinsko prikupljanje nalaza i probno sondiranje na nekoliko strateški odabranih mjesta rezultiralo je vađenjem novih predmeta, među kojima se posebno ističe veća količina ulomaka staklenoga stolnog posuđa prikupljenoga s površine velikog „polja stakla“ jugozapadno od glavnoga nalazišta (sl. 3-4). Pokušaj nastavka istraživanja 1997. godine ostao je bez uspjeha, pa je nalazište ponovno prepušteno devastaciji i degradaciji.
In 1996, the research was briefly renewed on the initiative of Zdenko Brusić (Brusić 1996), who had actively participated in the first rescue campaign thirty years earlier. Surface collection of finds and trial excavation at several strategically selected positions resulted in the recovery of new objects, among which were many fragments of glass tableware, collected from the surface of a large"glass field" south-west of the main shipwreck site (Figs. 3-4). An attempt to continue the exploration in 1997 was ultimately unsuccessful, so the site was again left to devastation and degradation.

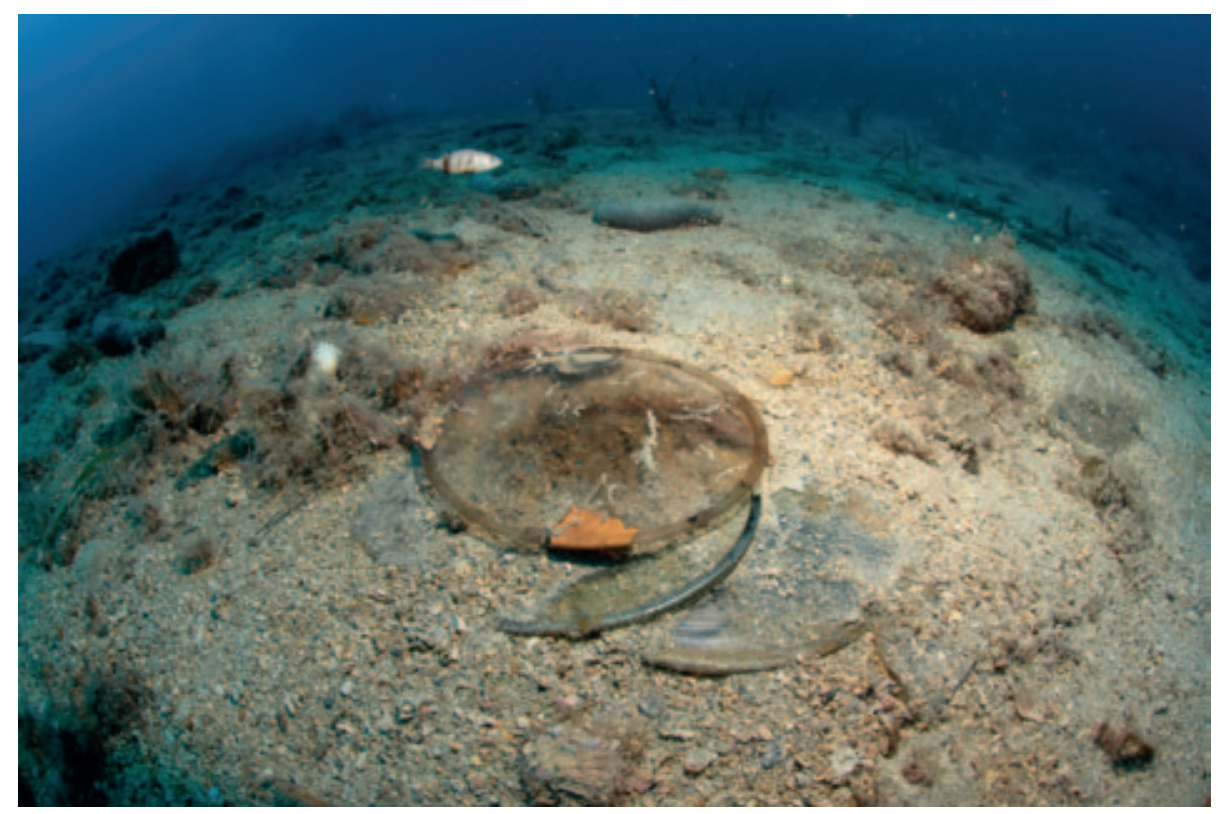

SI. 5 Cjelovita prozorska stakla u površinskom sloju nalazišta, 2005. (snimio: D. Frka) Fig. 5 Complete window panes in the surface layer of the site, 2005 (photo by: D. Frka)

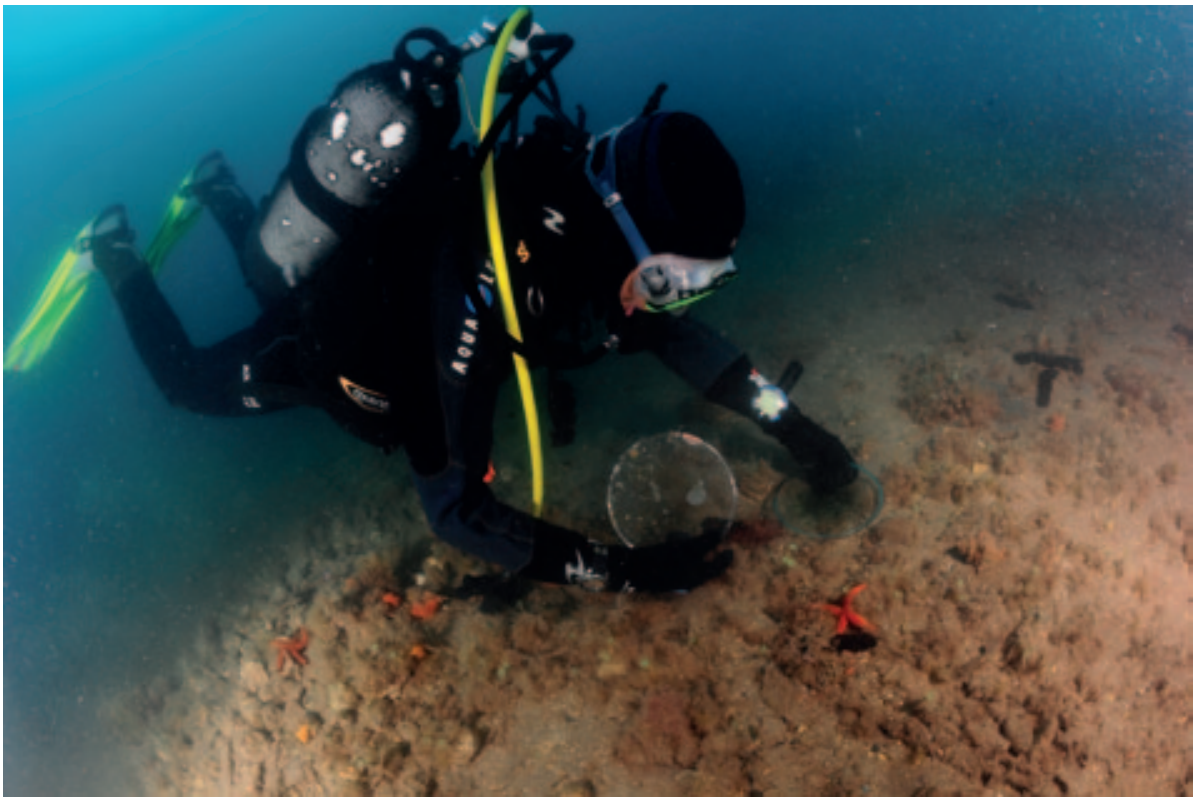

Sl. 6 Cjelovita prozorska stakla u površinskom sloju nalazišta, 2011. (snimio: M. Brzac)

Fig. 6 Complete window panes in the surface layer of the site, 2011 (photo by: M. Brzac) 
Stručni očevidi organizirani 2005. i 2011. godine potvrdili su arheološki potencijal i ugroženost nalazišta, ${ }^{5}$ a u oba slučaja na površini morskoga dna uočeni su cjeloviti primjerci okruglih prozorskih stakala (sl. 5-6). Godine 2012. istraživanje je ponovno pokrenuto pod vodstvom Irene Radić Rossi (Radić Rossi et al. 2013: 90), s ciljem sustavnoga proučavanja ostataka potonulog broda. Istraživanje je i danas u tijeku, a procjenjuje se da je istražena tek jedna petina nalazišta.

U međuvremenu, godine 2004. u okviru projekta The Heritage of the Serenissima ${ }^{6}$ započeo je rad na obradi nalaza pohranjenih u Zavičajnome muzeju Biograd na Moru koji je rezultirao objavom bogato ilustrirane publikacije namijenjene široj javnosti nizom tekstova u zborniku znanstvenoga skupa održanog 2005. u Izoli u Sloveniji te monografijom na temu stakla iz brodskoga tereta autora
Expert surveys organized in 2005 and 2011 confirmed the archaeological potential of the site and the threat of looting, ${ }^{5}$ and the presence of entirely preserved round window panes in the surface layer (Figs. 5-6). In 2012, the research restarted under the leadership of Irena Radić Rossi (Radić Rossi et al. 2013: 90), with the aim of the systematic study of the shipwreck remains. Exploration is still underway, and it is estimated that only one-fifth of the site has been explored.

In the meantime, under the framework of The Heritage of the Serenissima Project, ${ }^{6}$ in 2004 the work began on processing the finds stored in the Local Heritage Museum of Biograd na Moru. It resulted in the publication of a richly illustrated book for the general public, a series of texts in the proceedings of a scientific conference held in 2005 in Izola, Slovenia, and a monograph on glass from the ship's

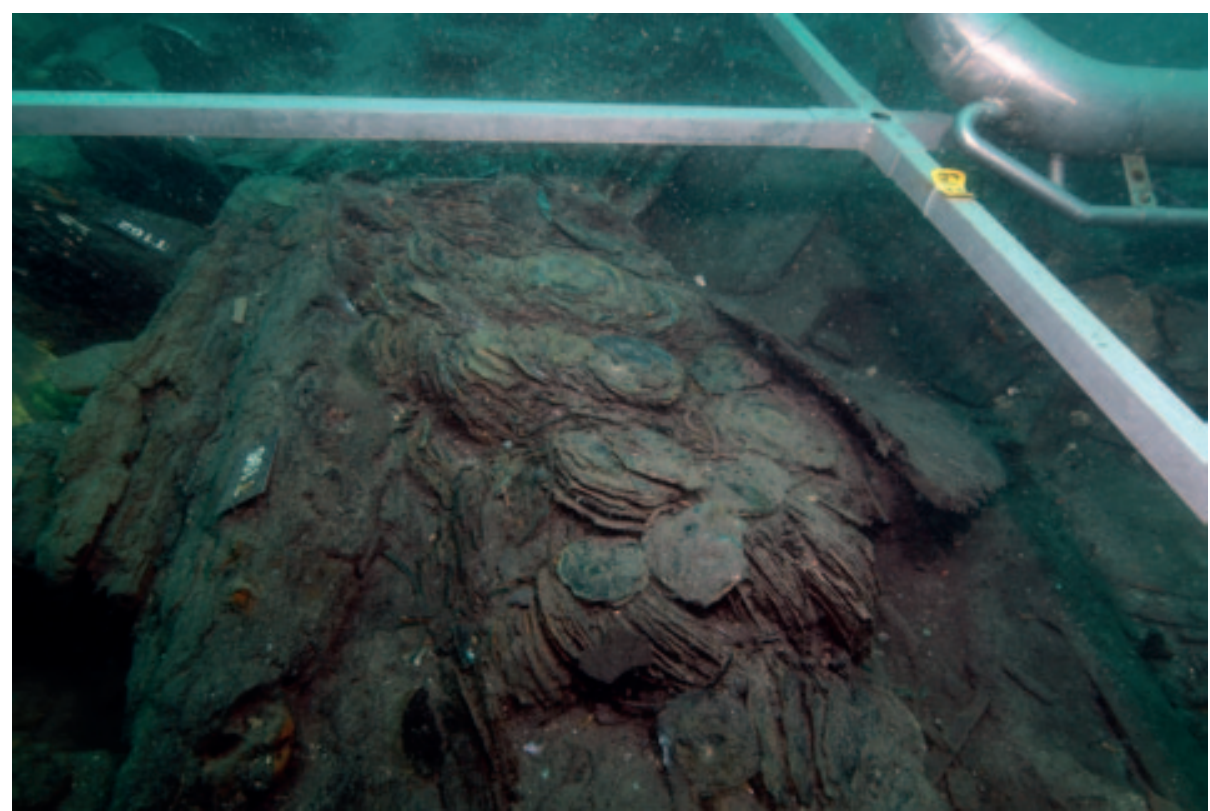

SI. 7 Nizovi ravnih stakala nad ostatcima prve palube, 2020. (snimio: M. Martinčak)

Fig. 7 Rows of flat glass over the remains of the first deck, 2020 (photo by: M. Martinčak)

Irene Lazar i Hugha Willmotta (Mileusnić 2004; 2006; Guštin et al. 2006; Lazar, Willmott 2006a). lako je riječ o detaljnoj analizi staklene građe, iz pregleda su, zbog velike brojnosti i raznolikosti, izostavljene staklene perle (Lazar, Willmott 2006b). Sustavna obrada tih predmeta započela je 2017. godine pod vodstvom Adelphine Bonneau i Katarine Batur, a tijekom radionice održane u srpnju u Zavičaj-

5 Stručni očevidi provedeni su pod vodstvom Irene Radić Rossi, 2005. u okviru snimanja serijala Veliki brodolomi Jadrana, a 2011. kao terenski dio programa radionice Brodolom kod Gnalića: Povijest istraživanja, problematika konzerviranja arheoloških nalaza, primjena podvodne informacijsko-komunikacijske tehnologije i planovi za budućnost, organizirane u okviru projekta ARS NAUTICA - Obrazovni program u području arheologije i povijesti pomorstva, koji je financijski podržao UNESCO Participacijski program 2010. - 2011.

6 Projekt je pokrenuo Inštitut za dediščino Sredozemlja s pročelnikom Mitjom Guštinom (Univerza na Primorskem, Koper, Slovenija), u suradnji sa Saurom Gelichijem (Università Ca' Foscari, Venezia, Italija) i Konradom Spindlerom (Universität Innsbruck, Austrija), u okviru EU programa Culture 2000. cargo by Irena Lazar and Hugh Willmott (Mileusnić 2004; 2006; Guštin et al. 2006; Lazar, Willmott 2006a). Although the monograph is a detailed analysis of glassware, glass beads were omitted due to their large number and variety (Lazar, Willmott 2006b). Systematic processing of these objects began in 2017 under the leadership of Adelphine Bonneau

5 Expert surveys were conducted under the guidance of Irena Radić Rossi, in 2005 as part of the filming of the series Great Shipwrecks of the Adriatic, and in 2011 as a fieldwork part of the workshop The Shipwreck of Gnalić: History of research, conservation of archaeological finds and application of underwater information technology, realized in the framework of the project ARS NAUTICA - Educational program in the field of archaeology and maritime history, financially supported by the UNESCO Participation Program 2010-2011.

6 The project was realized by the Institute for Mediterranean Heritage, under the direction of Mitja Guštin (University of Primorska, Koper, Slovenia), in collaboration with Sauro Gelichi (Università Ca' Foscari, Venice, Italy) and Konrad Spindler (Universität Innsbruck, Austria), within the EU program culture 2000. 
nome muzeju u Biogradu na Moru identificirano je preko 70 tipova. $^{7}$

Staklo s broda nekoliko je puta u novije vrijeme predstavljeno javnosti u okviru velikih tematskih i manjih povremenih izložbi te pratećih kataloga (Lazar 2010; Fadić 2011; Radić Rossi 2012; Jović Gazić 2015; Filep et al. 2013; Ratković Bukovčan 2013). Prilikom pripreme izložbe u Hrvatskome povijesnom muzeju u Zagrebu, kataloška obrada staklene građe dovela je do nekih novih spoznaja na koje je upozorila Ana Filep (Filep 2013: 59-60). Obnovljeno podmorsko istraživanje rezultiralo je otkrićem nekoliko nalaza koji odstupaju od do sada poznatih varijanti određenih tipova staklenoga stolnog posuđa i ravnoga stakla, a tijekom obrade tih predmeta ${ }^{8}$ uočena su i neka odstupanja od do sada objavljenih zaključaka. Osim toga, nova istraživanja rezultirala su i novim spoznajama o položaju i očuvanosti brodske olupine, a time i rasporedu i količini stakla u brodskome teretu (sl. 7). ${ }^{9}$ Arhivska istraživanja u Državnome arhivu u Veneciji dovela su do otkrića niza dokumenata o brodu, brodovlasnicima, trgovcima, posadi i teretu, čime se također znatno doprinijelo interpretaciji repertoara staklenih predmeta. $U$ ovome radu predstavljeni su novi nalazi i zapažanja, s ciljem dopune dosadašnjih spoznaja i poticaja na daljnji rad na proučavanju ove iznimno vrijedne i precizno datirane zbirke staklenih predmeta iz vremena kasne renesanse.

\section{PREGLED SPOZNAJA O STAKLENIM PREDMETIMA IZ BRODSKOGA TERETA DO 2006.}

Stakleni predmeti pronađeni u okviru zatvorene cjeline nalazišta broda potonuloga kod otočića Gnalića znatno su doprinijeli definiranju tipologije i kronologije kasnorenesansnoga stakla s prostora Venecije (Gasparetto 1973: 446), a njihova količina i raznolikost značajni su za proučavanju proizvodnje, transporta, trgovine i tržišne potražnje u posljednjoj četvrtini 16. stoljeća. Većina autora koji su se do sada njima bavili podijelili su ih u skupine bijeloga (lat. vitrum blanchum) i obojenoga stakla. Iz druge skupine u prvim je istraživačkim kampanjama šezdesetih godina prošloga stoljeća pronađeno samo staklo plave boje (Petricioli 1970: 27-28). Kasnija istraživanja pokazala su da su se u

7 Tematska radionica pod imenom Gnalić Beads Workshop održana je u okviru projekta AdriaS (HRZZ IP-09-2014-8211) u Zavičajnome muzeju Biograd na Moru i Institutu za pomorsku baštinu ARS NAUTICA u Tkonu u vremenu od 18. do 28. srpnja 2017.

8 Nalazi su obrađeni za potrebe izrade diplomskoga rada I. Šelendić, pod imenom Proizvodnja stakla u 16. st. na Jadranu i novi nalazi s otočića Gnalića (mentor: I. Radić Rossi), obranjenoga u listopadu 2017. na Sveučilištu u Zadru. Za ovu objavu, poglavlja o povijesti istraživanja i novim nalazima dopunjena su podacima koji nisu sadržani u diplomskome radu.

9 Interdisciplinarno proučavanje broda potonuloga kod Gnalića i njegovog kulturno-povijesnoga i gospodarsko-političkoga konteksta u vremenu od 2015. do 2019. godine realiziralo se u okviru projekta AdriaS (Archaeology of Adriatic Shipbuilding and Seafaring / Arheologija jadranske plovidbe i brodogradnje, IP-09-2014-8211) koji je financijski podržala Hrvatska zaklada za znanost. and Katarina Batur. During the workshop held in July at the Local Heritage Museum of Biograd na Moru, over 70 types were identified. ${ }^{\text {? }}$

Recently, glass finds from the shipwreck site have been presented to the public in some large thematic and small occasional exhibitions, and accompanying catalogues (Lazar 2010; Fadić 2011; Radić Rossi 2012; Jović Gazić 2015; Filep et al. 2013; Ratković Bukovčan 2013). During the preparation of the exhibition at the Croatian History Museum in Zagreb, the work on glass material led to some new insights, pointed out by Ana Filep (Filep 2013: 59-60). The restarted underwater research resulted in the discovery of some finds that deviate from the hitherto known variants of certain types of glass tableware and flat glass. During the processing of these items, ${ }^{8}$ some deviations from the conclusions published so far were noticed. In addition, recent research has resulted in new insights into the orientation and state of preservation of the shipwreck, and thus the original position and amount of glass in the ship's cargo (Fig. 7). ${ }^{9}$ Archival research at the State Archives in Venice led to the discovery of a series of documents on the ship, ship-owners, merchants, crew and cargo, which also significantly contributed to the interpretation of the glassware repertoire. In this paper, new finds and observations are presented, with the aim of supplementing the current knowledge and incentives for further work on the study of this extremely valuable and precisely dated collection of glass objects from the Late Renaissance.

\section{KNOWLEDGE ABOUT GLASS OBJECTS FROM SHIP CARGO UP TO 2006.}

Glass objects found on the shipwreck of Gnalic significantly contributed to defining the typology and chronology of Late Renaissance glass from Venice (Gasparetto 1973:446).Their quantity and diversity became important for studying production, transport, trade and market demand during the last quarter of the $16^{\text {th }}$ century. Most of the authors divided them into groups of white (lat. vitrum blanchum) and coloured glass. In the earliest research campaigns in the 1960 s, only blue glass, belonging to the second group, was found (Petricioli 1970: 27-28). Subsequent research has shown that the ship's cargo also

7 The thematic workshop entitled The Gnalic Beads Workshop was held in the framework of the AdriaS Project (HRZZ IP-09-2014-8211), at the Local Heritage Museum of Biograd na Moru and the ARS NAUTICA Institute for Maritime Heritage in Tkon, from 18 to 28 July 2017.

8 The finds were processed for the purposes of the Master thesis of I. Šelendić, entitled Production of glass in the $16^{\text {th }}$ century in the Adriatic, and new finds from the island of Gnalić (mentor: I. Radić Rossi), defended in October 2017 at the University of Zadar. For this paper, the chapters on research history and new finds are supplemented with data not contained in the thesis.

9 In the period from 2015 to 2019, interdisciplinary study of the shipwreck of Gnalić and its cultural-historical and economic-political context was realized within the AdriaS Project (Archaeology of Adriatic Shipbuilding and Seafaring, IP-09-2014-8211), financially supported by the Croatian Science Foundation. 
brodskome teretu nalazili i višebojni predmeti te predmeti zelene i crvene boje (Lazar, Willmott 2006a: 60-65). ${ }^{10}$

Po pitanju kvalitete izrade, Sofija Petricioli podijelila je stolno posuđe na luksuzno i jednostavno (Petricioli 1970: 23), dok je u kasnijoj literaturi razlika u kvaliteti staklene sirovine ilustrirana veličinom i gustoćom mjehurića koje se povećavaju s padom kvalitete. Predmeti lošije kvalitete često su iskrivljenoga oblika i od nepročišćene staklene smjese čime ukazuju na proizvodne centre u srednjoj Europi ili sjevernoj Italiji izvan Venecije. S druge strane, iako postoje pomno ukrašeni stakleni predmeti koji bi ukazivali na proizvodnju u Veneciji, značajna je odsutnost dekorativnih tipova povezanih $\mathrm{s}$ tom proizvodnjom. Kemijske analize provedene su kako bi se pokušalo preciznije odrediti podrijetlo stakla (Jackson 2009: 138).

Predmeti iz brodskoga tereta broda potonuloga kod Gnalića bili su namijenjeni širokome tržištu i različitim kupcima, na što prije svega ukazuje njihova tipološka i funkcionalna raznolikost." Irena Lazar i Hugh Willmott, isključivši iz obrade staklene perle, podijelili su staklene nalaze $u$ skupinu staklenoga posuđa i ravnoga stakla, pri čemu prva skupina obuhvaća stolno i ambalažno posuđe, a druga stakla za prozore i ogledala (Lazar, Willmott 2006a; 2006b; Lazar 2015: 269). Tri desetljeća ranije Astone Gasparetto predložio je, međutim, podjelu na A) šuplje staklo (tal. vetri cavi) $^{12}$, B) ravno staklo (tal. vetri piani) i C) staklene perle (tal. perle di vetro), u koju se mogu uklopiti i drugi 'šuplji' stakleni predmeti koji ne pripadaju nužno stolnome ili ambalažnome posuđu (Gasparetto 1976: 430).

U sveobuhvatnoj objavi staklene građe Irene Lazar i Hugha Willmotta pod pojmom stolnoga posuđa (S1 - S25) obuhvaćeni su sljedeći oblici (sl. 8): čaše, čaše na nožici, vrčevi, zdjele, poklopci, pladnjevi (podnosi) na nozi i vaze, svi izrađeni od bijeloga stakla i podijeljeni u više varijanti, te male zdjele, vrčevi, zaobljene i kvadratne boce izrađeni od obojenoga stakla. Ambalažnoj su skupini pripisani spremnici podijeljeni u raspršivače, bočice, boce i staklenke. Iz te se skupine donekle izdvajaju kruškolike bočice koje su možda bile namijenjene izradi pješčanih satova (Lazar, Willmott 2006a: 75).

Čaše se dijele u dvije kategorije. Prvoj skupini (S1) ${ }^{13}$ pripadaju jednostavne neukrašene čaše $s$ više ili manje udubljenim dnom koje se razlikuju po promjeru. Drugu skupinu (S2 - S7) tvore čaše na nozi zabilježene u vrijeme

10 U izradi obojenoga stakla muranski su majstori koristili dodatke poput kobalta za plavu, magnezija za ljubičastu i bakra za zelenu, crvenu i tirkiznu te željeza za zelenu, plavo-zelenu i žutu boju (Verità 2014: 58-59).

11 I. Lazar i H. Willmott (2006a) podijelili su do tada poznate predmete u dvije skupine podijeljene na 29 podskupina (prema potrebi dodatno podijeljenih na varijante). Prva skupina obuhvaća stakleno posuđe podijeljeno u podskupine S1 - S26, a druga ravno staklo podijeljeno u skupine S27 - S29.

12 Sukladno staklarskoj terminologiji, šuplje staklo u današnje vrijeme obuhvaća ambalažno staklo, stakleno posuđe, staklene cijevi, staklo za rasvjetna tijela i žarulje (Hrvatska enciklopedija, Leksikografski zavod Miroslav Krleža, http://www.enciklopedija.hr/natuknica.aspx?id=57714, 03. 06. 2018.). U Gasparettovoj podjeli pojam šuplje staklo obuhvaća ambalažno staklo i stakleno posuđe.

13 Tipološke oznake koje započinju slovom S preuzete su iz publikacije I. Lazar i H. Willmotta (2006a). contained multi-coloured, green and red objects (Lazar, Willmott 2006: 60-65). ${ }^{10}$

In terms of quality of production, Sofija Petricioli divided tableware into luxurious and simple (Petricioli 1970: 23), while in later literature the difference in the quality of raw glass material was illustrated by the size and density of bubbles, increasing with decreasing quality. Poor quality items are often distorted in shape and made of crude glass mixture, pointing to production centres in Central Europe or northern Italy, outside Venice. On the other hand, although there are carefully decorated glass objects that would indicate production in Venice, there is a significant absence of decorative types associated with that production. In order to attempt the more accurate determination of the origin of the glass, chemical analyses were performed (Jackson 2009: 138).

Items from the ship cargo were intended for a wide market and various customers, which can be deduced from their typological and functional diversity. ${ }^{11}$ Irena Lazar and Hugh Willmott divided the glass finds into groups of vessel glass and flat glass, with the first group comprising tableware and containers, and the second window panes and mirrors (Lazar, Willmott: 2006a, 2006b; Lazarus 2015: 269). As previously stated, they excluded the glass beads from their work. Three decades earlier, Astone Gasparetto proposed, however, a division into A) hollow glass (vetri cavi $^{12}$, B) flat glass (vetri piani), and C) glass beads (perle di vetro), into which could fit the other 'hollow' glassware that does not necessarily belong to tableware or containers (Gasparetto 1976: 430).

In the comprehensive publication of glassware by Irena Lazar and Hugh Willmott, the following forms, designated S1 - S25, were included under the term tableware (Fig. 8): beakers, goblets, tankards, bowls, lids, tazzae and vases, all made of white glass and divided into several variants, and small bowls, jugs, oval and square bottles, made of coloured glass. Containers were divided into sprinklers, flasks, bottles and jars. From this group, pear-shaped bottles, which may have been intended for making hourglasses, stand out (Lazar, Willmott 2006a: 75).

The beakers and goblets are divided into two groups. The first group $(\mathrm{S} 1)^{13}$ includes plain beakers with a pushedin base that differ in diameter. The second group (S2 - S7) consists of goblets, recorded in Italy in the $14^{\text {th }}$ century, and in Central and Eastern Europe in the $16^{\text {th }}$ century. The

10 In making coloured glass, Murano masters used additives such as cobalt for blue, magnesium for purple and copper for green, red and turquoise, and iron for green, blue-green and yellow (Verità, 2014: 58-59).

11 I. Lazar and H. Willmott (2006a) divided the known objects into two groups divided into 29 subgroups (further divided into variants, if necessary). The first group comprises vessel glass divided into subgroups \$1 - S26, and the second flat glass divided into groups S27 - S29.

12 According to glass terminology, hollow glass now includes containers, vessel glass, glass tubes, glass for lighting and light bulbs (Croatian Encyclopaedia, Miroslav Krleža Lexicographic Institute, http://www.enciklopedija.hr/ natuknica. aspx?id= 57714, 3 June 2018). In Gasparetto's division, the term hollow glass includes containers and vessel glass.

13 Typological labels beginning with the letter $S$ are taken from the publication I. Lazar and H. Willmott (2006a). 


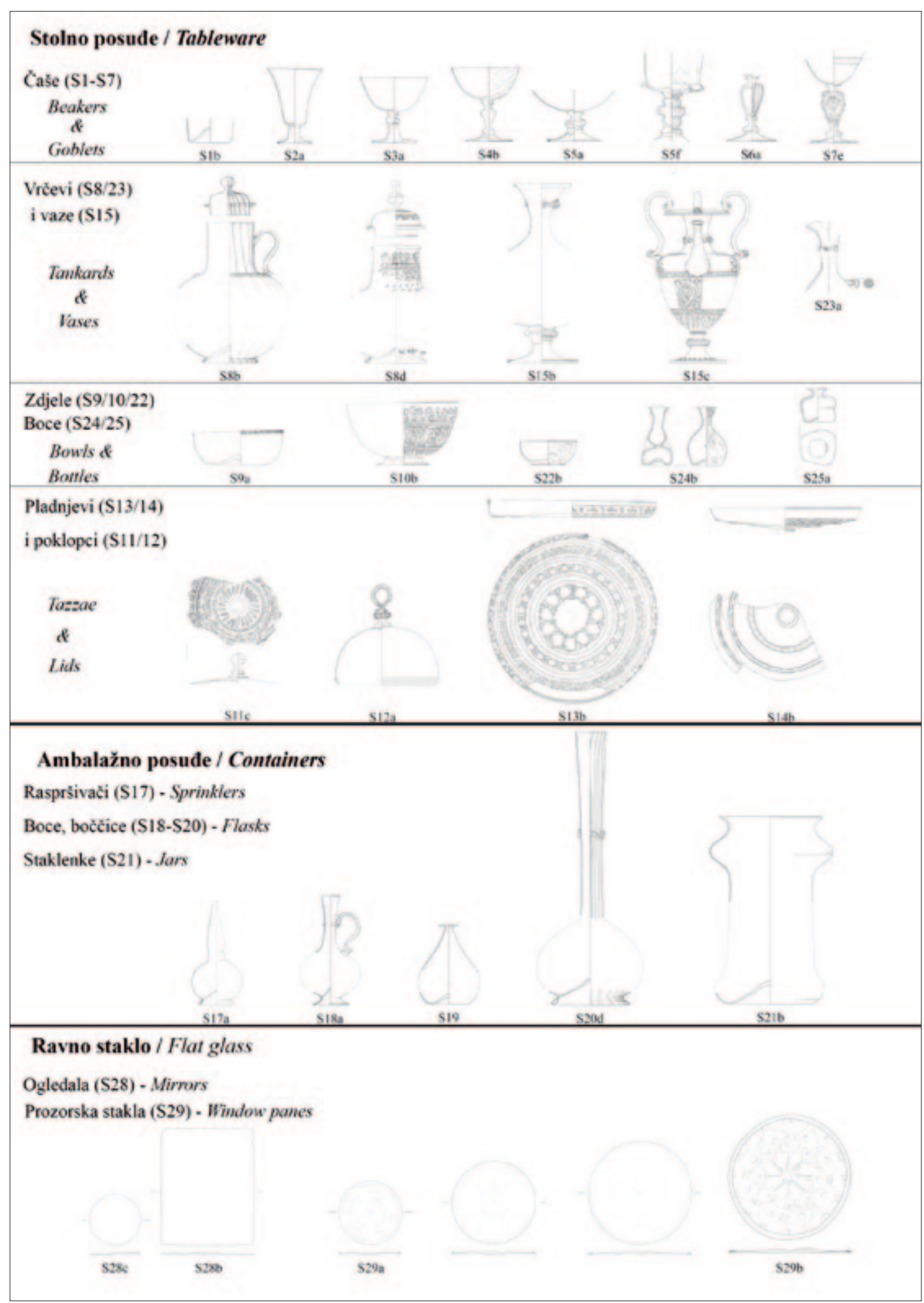

SI. 8 Osnovni oblici stolnoga i ambalažnoga posuđa zastupljeni u teretu broda (prema: Lazar, Willmott 2006a) Fig. 8 Basic forms of table and packaging utensils represented in the cargo of the ship (after: Lazar, Willmott 2006a)

renesanse u Italiji u 14. stoljeću, a u centralnoj i istočnoj Europi u 16. stoljeću. Čaška je visoko uzdignuta pomoću šupljega podnožja ili nožice ukrašene nodusom u obliku obrnutoga balustra, plosnato narebrenoga prstena motivom ljestvi ili lavlje maske. Ova tipološki opsežna skupina čini najbrojniju kategoriju staklenih predmeta pronađenih bowl is raised high by a hollow foot or stem, decorated with inverted baluster, flattened knop, ladder or lion mask. This typologically extensive group makes up the most numerous category of glass objects found at the shipwreck of Gnalić. They are made of two or three elements: the upper part, i.e. the bowl, the middle part, i.e. the stem, and the foot 
na brodolomu kod otočića Gnalića. Napravljene su od dva ili tri elemenata: gornjega dijela, tj. čaške, srednjega dijela, tj. noge i podnožja na kojemu stoje. Čaše su podijeljene u podskupine ovisno o veličini, obliku i načinu ukrašavanja noge, čaške i podnožja. Svi elementi predmeta izrađeni su puhanjem, ponekad različitim tehnikama. Slobodnim puhanjem ili puhanjem u kalupu izrađena je nožica, dok su neki primjerci čaške bili izrađeni optičkim puhanjem ili slobodnim puhanjem, nakon čega se staklo ukrašavalo graviranjem (Lazar, Willmott 2006a: 26-39; Lazar 2015: 269-271).

Vrčevi oblika S8 služili su za ispijanje ili izlijevanje pića, kao staklene posude pojavljuju se početkom 16. stoljeća, a koriste se i krajem 17. stoljeća (Willmott 2002: 55). Među teretom su se sačuvali elementi vrata, ručki i poklopca s prihvatom, a uz neke tipove moguće je povezati i dna s udubljenjem. Za sada su poznate četiri varijante ukrasa koje se pojavljuju na oplošjima tijela i poklopcima. Na staklenim vrčevima pronađenim na brodolomu kod otočića Gnalića izdvajaju se ukrasi izvedeni u tehnici vetro a fili i vetro a retorti, s istaknutim nitima mliječnoga stakla (tal. lattimo) te ukrasi nastali u tehnici graviranja dijamantnom iglom, $\mathrm{s}$ iscrtanim motivima listova i uvijenoga lišća (Lazar, Willmott 2006a: 40; Lazar 2015: 27).

Zdjele (S9 - S10) su otvorene posude čija je primarna uporaba privremeno skladištenje ili posluživanje hrane na stolu. U sekundarnoj uporabi služile su za pranje ruku ili kao posude za piće. Njihov polukružan oblik dopuštao je jednostavno slaganje jedne na drugu. No, budući da su bile izrađene od tankoga puhanog stakla, često su sačuvana samo podnožja. Male zdjele imale su rub ukrašen tehnikom vetro a retorti u kojem su bijele i plave niti bile isprepletene, a samo je jedna zdjela ukrašena graviranjem očuvana u cijelosti (Lazar, Willmott 2006a: 44-45; Lazar 2015: 271-272).

Poklopci (S11 - S12) tvore malu skupinu stakla koja je preživjela na morskome dnu. Njihovu točnu pripadnost teško je odrediti, no pretpostavlja se da su bili povezani sa zdjelama, iako su neki od njih zasigurno bili sastavni dijelovi vrčeva. Stakleni poklopci dijele se na poklopce ravne površine i poklopce u obliku kupole. Izrađeni su slobodnim ili optičkim puhanjem, a razlikuju se i ovisno o graviranom ukrasu (Lazar, Willmott 2006a: 45-46; Lazar 2015: 271).

$\mathrm{U}$ skupinu $\mathrm{s}$ malim brojem pronađenih primjeraka ubrajaju se i pladnjevi (podnosi) na nozi (S 13 - S14). Osnovni elementi ovih predmeta su zdjela i nožica koja se niti u jednome slučaju nije očuvala već je vidljiva u tragu koji upućuje na činjenicu da je doista postojala. Primjeri zdjela ukrašeni su s naizmjeničnim neprozirnim trakama izvedenim u tehnici filigrana vetro a filli i vetro a retorti te tehnikom graviranja dijamantnom iglom. Neki primjerci ukrašeni su valovitim ili običnim staklenim trakama koje prate kružni obod zdjele (Lazar, Willmott 2006a: 47; Lazar 2015: 271-272).

Vaze (S15 - S16) su posude koje mogu imati dekorativnu ili utilitarnu namjenu. One pripadaju posebnoj grupi zbog svoje karakteristične forme te su vjerojatno, ovisno o veličini, korištene u različite svrhe. Pretpostavka je da su on which they stand. Goblets are divided into subgroups, depending on the size, shape and method of decorating the stem, bowl, and foot. All the elements of the object were made by blowing, sometimes by different techniques. Freeblowing or mould-blowing was used to produce the stem, while some bowls were made by optical blowing or freeblowing, after which the glass was decorated by engraving (Lazar, Willmott 2006a: 26-39; Lazar 2015: 269-271).

Tankards from the group S8 were used for drinking or pouring drinks. They appeared as glass vessels at the beginning of the $16^{\text {th }}$ century, and were also used at the end of the $17^{\text {th }}$ century (Willmott 2002: 55). Among the cargo, elements of the necks, handles and lids with solid finial have been preserved, and with some types it is possible to connect the pushed-in bases. For now, four variants of decorations are known, which appear on the bodies and lids. The glass tankards found at the shipwreck of Gnalić include ornaments made in the technique of vetro $a$ fili and vetro $a$ retorti, with prominent opaque white glass/trails (Iattimo), and ornaments made in the diamond needle engraving technique, with motifs of leaves and twisted leaves (Lazar, Willmott 2006a: 40; Lazar 2015: 27).

Bowls (S9 - S10) are open vessels whose primary use is the temporary storage or serving of food on a table. In secondary use, they served for washing hands or as drinking bowls. Their semi-circular shape allowed for easy stacking on top of each other. Since they were made of thin blown glass, often only the bases are preserved. The small bowls had an edge decorated with the vetro a retorti technique, in which white and blue trails were intertwined. Only one bowl, decorated with engraving, was entirely preserved (Lazar, Willmott 2006a: 44-45; Lazar 2015: 271-272).

The lids (S11 - S12) form a small group of glass that survived on the seabed. Their exact function is difficult to determine, but it is assumed that they were associated with bowls, although some of them were possibly integral parts of tankards. Glass lids are divided into flat dish lids and domed lids. They are made by free or optical blowing, and differ depending on the engraved decoration (Lazar, Willmott, 2006a: 45-46; Lazar 2015: 271).

The group with a small number of specimens also includes tazzae (S13 - S14). The basic elements of these objects are a bowl and a stem, which in no case has been preserved, but is visible in the trace that indicates that it really existed. Bowls are decorated with alternating applied opaque trails, made in the filigree technique of vetro a fili and vetro a retorti, and the technique of engraving with a diamond needle. Some specimens are decorated with wavy or plain glass trails that follow the circular rim of the bowl (Lazar, Willmott 2006a: 47; Lazar 2015: 271-272).

Vases (S15 - S16) are vessels of decorative or utilitarian purpose. They belong to a special group due to their characteristic shape, and were probably, depending on size, used for different purposes. It is assumed that smaller vases served as vessels for holding flowers or as a decoration on the table, while larger vases were used to store perfume or as receptacles for wine. The body of the vessel is ovoid 
manje vaze služile kao posude za držanje cvijeća ili kao ukras na stolu, dok su se veće vaze koristile za pohranjivanje parfema ili kao posude za vino. Tijelo posude jajolikoga je oblika s uskim vratom i obodom izvijenim prema van koji je ponekad opremljen istaknutim izvijenim lijevkom. Na osnovi njihove elegantne dekoracije i kompleksnih oblika, vaze pripadaju kategoriji skupocjenih predmeta. Sve vaze pronađene na brodolomu kod Gnalića pripadaju tipu vaza s nožicom, a najljepši primjerci bili su ukrašeni graviranjem dijamantnom iglom. Vrlo dragocjen tip vaze na nožici s tri ručke i lijevkom koji se nije sačuvano u punini rekonstruiran je prema vazi pronađenoj u privatnome stanu u Beču (Lazar, Willmott 2006a: 50-51; Lazar 2015: 273).

Zasebnu kategoriju staklenih predmeta čine spremnici koju tvore raspršivači (S17), boce $(\mathrm{S} 18, \mathrm{~S} 20)$, kruškolike boce (S19), od kojih su se možda izrađivali pješčani satovi, te vratovi boca (S20) i staklenke (S21). Ta skupina staklenih predmeta nosila je ukras izveden u tehnici filigrana (vetro a fili) ili jednostavnu običnu ili valovitu traku, apliciranu oko vrata boce (Lazar, Willmott 2006a: 54; Lazar 2015: 273).

Raspršivači su bočice specifičnoga oblika čiji je sadržaj bio posve zatvoren, a činili su ga parfemi ili mirisna ulja. Odlikuju se uskim vrhom, kojeg je bilo potrebno ukloniti kako bi se sadržaj mogao iskoristiti. Suženja koja su se nalazila na vratu služila su kao mjesta na koja se mogao staviti pluteni čep spojen konopčićem. Takve posude u Europi se ne pronalaze često, a njihovo podrijetlo još je uvijek nesigurno kao i njihova namjena (Lazar, Willmott 2006a: 54; Lazar 2015: 273).

Bočice i boce korištene su za držanje tekućine kao što su ulje, ocat, voda ili vino. Osnovne razlike su dužina vrata te ručka koju bočica ima, a boca ne. Bile su izrađene slobodnim puhanjem ili puhanjem u kalupu. Prema arheološkome kontekstu slobodno puhane boce poznate su od kraja 11. i početka 12. stoljeća u Italiji te od kraja 12. i početka 13. stoljeća u Njemačkoj i Švicarskoj, dok su boce puhane u kalupu poznate od druge polovice 14. stoljeća kada postaju uobičajene, a njihova uporaba nastavlja se u 15. i 16. stoljeću (Lazar, Willmott 2006a: 55-58; Lazar 2015: 274).

Kruškolike boce svrstane su u skupinu posuda za pohranjivanje tekućina, ali nije isključena mogućnost njihove drugačije interpretacije. Oblikom odgovaraju staklenome dijelu pješčanoga sata, iako drvene konstrukcije satova nisu pronađene. Moguće je da su boce prevožene kao poluproizvod koji se u posebnim radionicama sklapao u cjelinu. Pojavljuju se u ranome 13. stoljeću u Italiji i koriste se sve do 18. stoljeća, kada dobivaju na vrijednosti i cijenjenosti (Willmott 2005). Pješčani sat izrađivao se spajanjem dviju kruškolikih boca preko oboda, njihovim učvršćivanjem pomoću metalnoga obruča i dodavanjem drvenoga okvira (Lazar, Willmott 2006a: 55, 75; Lazar 2015: 274).

U spremnike se ubrajaju i staklenke, posude za privremeno skladištenje hrane u kućanstvu ili za držanje lijekova u ljekarnama. Primjeri koji su pronađeni na Gnaliću vjerojatno su sadržavali sredstva za suzbijanje bolesti i lijekove koji su izgubljeni (Lazar, Willmott 2006a: 26-39). in shape, with a narrow neck and out-turned rim, which is sometimes fitted with a prominent spout. Based on their elegant decorations and complex shapes, vases belong to the category of expensive items. All the vases found at the shipwreck of Gnalić belong to the type of footed vases, and the most beautiful specimens are decorated with a diamond needle engraving. A very valuable type of footed vase with three handles and a spout, that has not been fully preserved, has been reconstructed based on a vase found in a private apartment in Vienna (Lazar, Willmott 2006a: 50-51; Lazar 2015: 273).

A separate category of glass objects consists of containers. It encompasses sprinklers (S17), bottles (S18, S20), pear-shaped bottles (S19) from which hourglasses may have been made, bottle necks (S20) and jars (S21). This group of glass objects was decorated by the filigree technique (vetro a fili) or a simple plain or wavy trail, applied around the neck of the bottle (Lazar, Willmott 2006a: 54; Lazar 2015: 273).

Sprinklers are completely closed bottles of specific shape, probably containing perfumes or fragrant oils. They had a narrow tip, which needed to be removed in order for the contents to be exploited. The constrictions of their necks served as places where a cork cap connected by a rope could be placed. Such vessels are not often found in Europe, and their origin is still uncertain, as is their purpose (Lazar, Willmott 2006a: 54; Lazar 2015: 273).

Bottles and flasks were used to hold liquids such as oil, vinegar, water or wine. The main differences are the length of the neck, and the handle present on the flasks, but not on the bottles. They were made by free blowing or blowing in a mould. According to the archaeological context, freely blown bottles have been known since the end of the $11^{\text {th }}$ and the beginning of the $12^{\text {th }}$ centuries in Italy, and from the end of the $12^{\text {th }}$ and the beginning of the $13^{\text {th }}$ centuries in Germany and Switzerland. The moulded bottles have been known since the second half of the $14^{\text {th }}$ century, when they become common, and their use continued in the $15^{\text {th }}$ and $16^{\text {th }}$ centuries (Lazar, Willmott 2006a: 55-58; Lazar 2015: 274).

Pear-shaped bottles are classified in the group of containers for storing liquids, but the possibility of a different interpretation is not excluded. The shape corresponds to the glass part of an hourglass, although no wooden construction of an hourglass frame has been found. It is possible that the bottles were transported as a semi-finished product, which was assembled into a whole in special workshops at the final destination. Hourglasses appear in the early $13^{\text {th }}$ century Italy and are used until the $18^{\text {th }}$ century, when they gain in value and appreciation (Willmott 2005). An hourglass was made by joining two pear-shaped bottles over the rim, securing them with a metal hoop, and adding a wooden frame (Lazar, Willmott 2006a: 55, 75; Lazar 2015: 274).

Containers also include jars, vessels for temporary storage of food in the household or for keeping medicines in pharmacies. The examples found at the Gnalić site probably contained disease control agents and drugs, which were lost (Lazar, Willmott 2006a: 26-39). 
Posljednja kategorija obuhvaća obojeno staklo. Unutar te skupine nalaze se male zdjele (S22), vrčevi (S23) te zaobljene i kvadratne bočice (S24 - S25) koji se razlikuju prema oblicima i funkcijama (Lazar, Willmott 2006a: 60; Lazar 2015: 275). Male zdjele moguće je povezati s fincān šalicama ili kās zdjelicama koje su se tijekom 16. i 17. stoljeća u Osmanskome Carstvu koristile u svakodnevnom životu. Njihova funkcija još uvijek je nepoznata, no mogle su se koristiti kao šalice za piće (čaj) ili zdjele za hranu. Podrijetlo vrčeva nije poznato, ali pronađeni predmeti odražavaju karakteristike islamskoga svijeta. U 9. stoljeću na prostoru Sirije proizvodilo se staklo $s$ karakterističnim trolisnim obodom, a slične posude izrađivale su se i u Jeruzalemu. U Osmanskome Carstvu tijekom 16. i 17. stoljeća za vrčeve je korišten naziv ibrik, ali je pitanje može li se isti naziv primijeniti i na naše vrčeve. Bočice su mogle biti u funkciji vrčeva, dok su one kvadratne vjerojatno služile kao tintarice (Lazar, Willmott 2006a: 60-65; Lazar 2015: 275).

Obojeno staklo s brodoloma kod otočića Gnalića pojavljuje se kao jednobojno, izrađeno tehnikom puhanja od neprozirnoga materijala, a najupečatljiviji su predmeti ukrašeni dodavanjem kuglica obojanoga stakla te predmeti izrađeni od kalcedonskoga stakla (Lazar 2015: 275).14 U staklenu ugrijanu smjesu dodavali su se komadići obojenoga stakla nakon čega bi se ona ponovno grijala sve dok se dodani komadići ne bi stopili. Pretpostavka je da su ovi proizvodi nastali u Zapadnoj Europi za istočno tržište (Lazar, Willmott 2006a: 60-62; Lazar 2015: 275).

Postoji manja skupina stakla kojoj se ne može odrediti točna pripadnost. Među njima se nalaze boce s dvostruko profiliranim rubom $s$ nejednakim prstenastim zadebljanjem kojim se ne odlikuje muranska produkcija. Velika boca, zbog svoje veličine i načina proizvodnje u kojem je obod oštro presječen, nejednak i trostrukoga presjeka, također ne odgovara zapadnim proizvodnim tradicijama. Predmeti iz te skupine okarakterizirani su kao produkt islamskoga svijeta (Lazar, Willmott 2006a: 62-64; Lazar 2015: 275).

Uz to, u brodskom su teretu bile prisutne i velike količine ravnoga stakla za prozore i ogledala. Sva prozorska stakla okrugloga su oblika, a obrubljena su šupljim prstenastim zadebljanjem. Osim po različitim dimenzijama, mogu se podijeliti u skupinu ukrašenih i neukrašenih stakala, od kojih je druga skupina daleko brojnija (Lazar, Willmott 2006a: 72). Stakla iz obje skupine izrazito su visoke kvalitete, a prilikom transporta bila su zaštićena slamom (sl. 9), za razliku od ranije opisanoga posuđa za koje se u literaturi navode dokazi o transportu u velikim košarama (Lazar, Willmott 2006a: 19-22). Valja, međutim, napomenuti kako su se tijekom istraživačke kampanje 2020. godine u zoni prekrivenoj ravnim staklima pronašli ostaci košara koje su vjerojatno iskorištene kao ambalaža za te proizvode (sl. 10).

Stakla za ogledala bila su prevožena kao poluproizvodi ili kao gotovi proizvodi. Sva nedovršena stakla za ogledala

\footnotetext{
14 Eng. Chalcedony glass. Višebojno staklo napravljeno od smeđih, plavih, zelenih i žutih zrnaca koja oponašaju kalcedon i poludrago kamenje. Krajem 15. stoljeća prvi je put proizvedeno u Veneciji. Corning Museum of Glass,
} http://www.cmog.org/glass-dictionary/calcedonio.
The last category includes coloured glass. Within this group are small bowls (S22), jugs (S23) and oval and square bottles (S24 - S25), which differ in shape and function (Lazar, Willmott 2006a: 60; Lazar 2015: 275). Small bowls can be associated with fincān cups or kās bowls that were used in everyday life during the $16^{\text {th }}$ and $17^{\text {th }}$ centuries in the Ottoman Empire. Their function is still unknown, but they could have been used as drinking cups (tea) or as food bowls. The origin of the jugs is unknown, but the items found reflect the characteristics of the Islamic world. In the $9^{\text {th }}$ century, glass with a characteristic trefoil rim was produced in Syria, and similar vessels were made in Jerusalem. In the Ottoman Empire during the $16^{\text {th }}$ and $17^{\text {th }}$ centuries, the name ibrik was used for jugs, but the question is whether the same name can be applied to these jugs. The oval-shaped bottles could have functioned as jugs, while the square ones probably served as inkwells (Lazar, Willmott 2006a: 60-65; Lazar 2015: 275).

Coloured glass from the shipwreck of Gnalić may appear as a single colour, made by the technique of blowing the opaque material, but the most impressive objects are those decorated with blobs of coloured glass and those made of chalcedony glass (Lazar 2015: 275). ${ }^{14}$ Pieces of coloured glass were added to the heated glass paste, after which it would be heated again until the added pieces melted. It is assumed that these products originated in Western Europe for the Eastern market (Lazar, Willmott 2006a: 60-62; Lazar 2015: 275).

There is a smaller group of glass to which the exact affiliation cannot be determined. In this group are oval bottles with uneven stepped and outs played rims, which is not a characteristic of Murano production. The large bottles, due to their sizes and method of production, in which the rim is sharply cut, uneven and of triple cross section, also do not correspond to Western production traditions. Objects from this group are characterized as products of the Islamic world (Lazar, Willmott 2006a 62-64; Lazar 2015: 275).

In addition, large quantities of flat glass for windows and mirrors were present in the ship's cargo. All window panes are round in shape and are bordered with folded edge. Apart from different dimensions, they can be divided into groups of decorated and undecorated glass, of which the second group is far more numerous (Lazar, Willmott 2006a: 72). The glasses from both groups are of extremely high quality, and during transport they were protected by straw (Fig. 9), in contrast to the previously described glassware for which evidence of transport in large baskets is given in the literature (Lazar, Willmot 2006a: 19-22). It should be noted that during the 2020 research campaign, in the area covered by flat glass, the remains of baskets were found that were probably also used as packaging for part of these products (Fig. 10).

Mirror glasses were transported as semi-finished or finished products. All unfinished glass for mirrors had a rectangular shape, while the finished products were

14 Multi-coloured glass made of brown, blue, green and yellow beads that mimic chalcedony and semi-precious stones. It was first produced in Venice in the late $15^{\text {th }}$ century. Corning Museum of Glass, http://www.cmog.org/ glass-dictionary/calcedonio. 


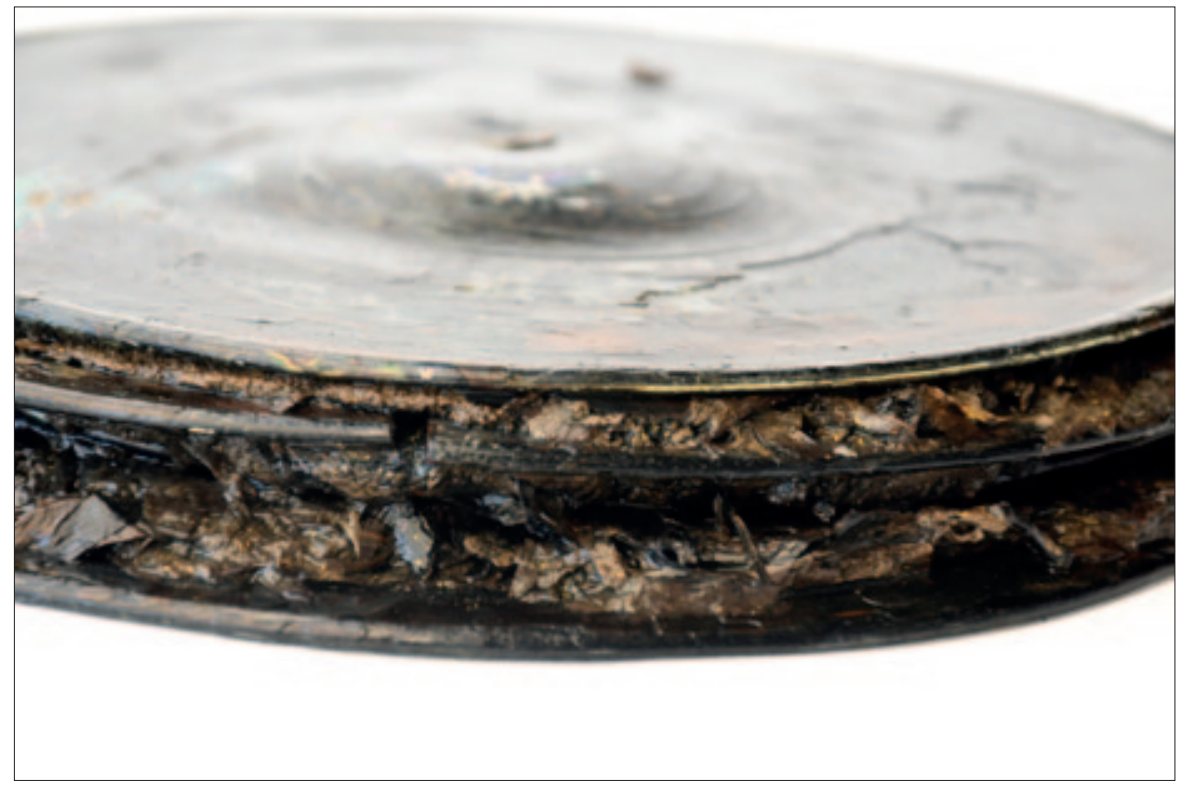

SI. 9 Slojevi slame među prozorskim staklima, 2020. (snimio: M. Martinčak) Fig. 9 Layers of straw between window panes, 2020 (photo by: M. Martinčak)

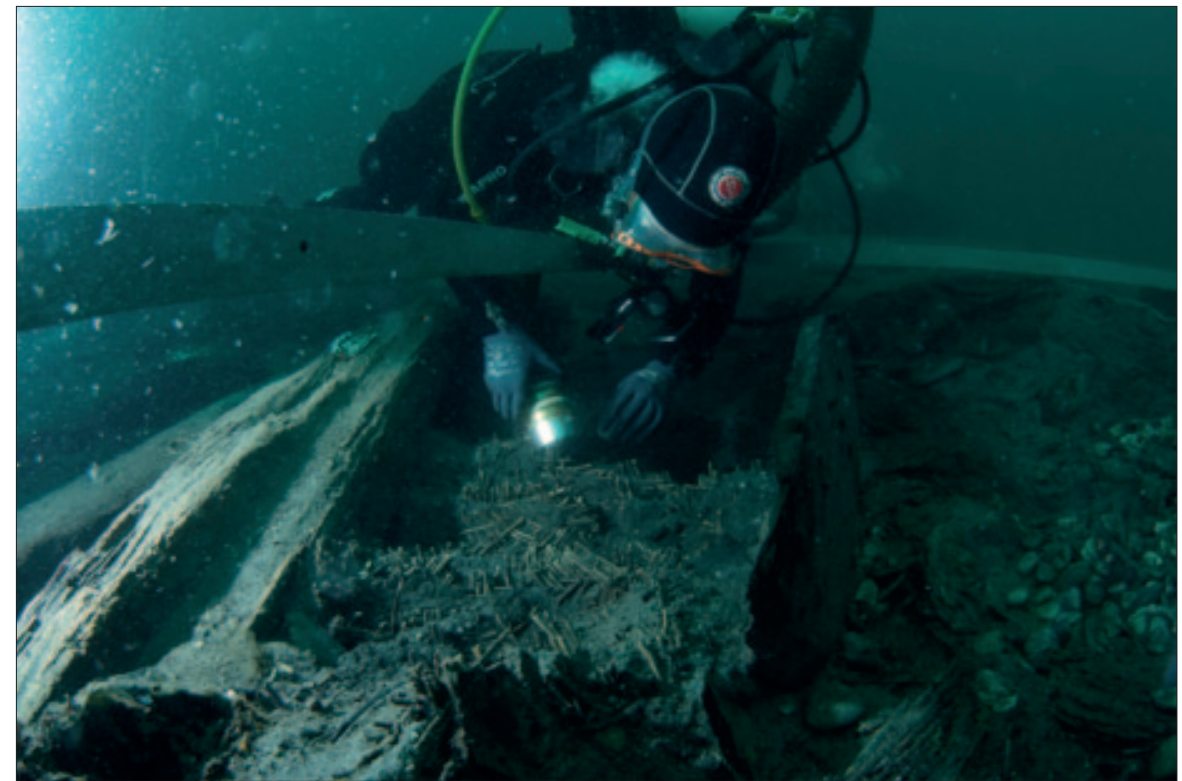

SI. 10 Ostaci košara pod nizovima ravnih stakala, 2020. (snimio: A. Hodalič) Fig. 10 Remains of baskets under rows of flat glass, 2020 (photo by: A. Hodalič)

imala su pravokutan oblik, dok su gotovi proizvodi bili pravokutnoga ili okrugloga oblika. ${ }^{15}$ Stakla su bila izrađena tehnikom lijevanja na ravnu kamenu površinu, nakon čega je slijedilo poliranje i rezanje na željenu veličinu. Nedovršena lijevana stakla za ogledala raspoznaju se po hrapavoj površini kojom je staklena masa dodirivala kamenu podlogu i po zaobljenim i nedovršenim rubovima. Za razliku od njih, gotova ogledala odlikuju se glačanom i poliranom površinom, ravno rezanim rubovima itragovima srebrnastoga reflektirajućeg pozadinskoga sloja koji se

15 I. Lazar i H. Willmott (2006a: 144) navode nedovršena pravokutna stakla za ogledala u dvije dimenzije, a dovršena pravokutna i dovršena okrugla stakla u tri dimenzije za svaku skupinu. rectangular or round. ${ }^{15}$ The glasses were made by casting on a flat stone surface, followed by polishing and cutting to the desired size. Unfinished cast glass for mirrors is recognizable by the rough surface with which the glass paste touched the stone base, and by the rounded and unfinished edges. In contrast, the finished mirrors are characterized by a polished surface, straight cut edges and traces of a silvery reflective background layer that was made by pouring mercury on a tin sheet. The reflective amalgam disintegrated in the seawater due to the corrosion of the tin, and the released

15 I. Lazar and H. Willmott (2006a: 144) cite unfinished rectangular glasses for mirrors in two dimensions, and completed rectangular and finished round glasses in three dimensions for each group. 
izrađivao nalijevanjem žive na kositreni lim. Reflektirajući amalgam u morskoj se vodi raspao zbog korozije kositra, a oslobođena živa i danas je prisutna na nalazištu. ${ }^{16}$ Gotova su ogledala, čini se, bila bez okvira i gusto složena jedno uz drugo, a kao materijal korišten pri pakiranju spominje se platno (Lazar, Willmott 2006a: 68-69).

Ostatak staklenih predmeta bio je izrađen tehnikom puhanja, uključivo slobodno puhanje, puhanje u kalup i optičko puhanje u kalup. Puhanje je izazvalo revoluciju u izradi stakla, jer su predmeti mogli imati tanke stjenke i biti proizvedeni u kratkome vremenu. Unutrašnjost kalupa mogla se oblikovati u različite forme u koje bi se zatim upuhivalo otopljeno staklo. Ukoliko se staklena smjesa oblikovala u kalupu za puhanje te dodatno puhala ili uvijala nakon što je izvađena iz kalupa, ukras je tada bio izrađen takozvanim optičkim puhanjem u kalupu (Davison 2006: 105; Fadić, Perović 2017: 55; Topić 2017: 48-52). Gnalićki predmeti koji su izrađeni optičkim puhanjem odlikuju se motivom saćaste mreže ili nizova kapljičastih motiva koji podsjećaju na češer. Klasični, odnosno izvorni način puhanja u kalup kojim se oblikuje dio staklene posude je upuhivanje staklenoga mjehura u kalup posebnoga oblika bez naknadnih intervencija (Fadić, Perović 2017: 44).

Prozorska stakla bila su izrađena posebnom tehnikom slobodnoga puhanja stakla u mjehur koji bi se zatim otvarao na kraju, a staklena smjesa bi se zavrtjela kako bi centrifugalne sile djelovale i stvorile pravilno oblikovanu staklenu ploču. Staklo s reljefnim ukrasom rozeta bilo je izrađeno tehnikom optičkoga puhanja. ${ }^{17}$

Po pitanju ukrašavanja kvalitetnijega posuđa, tehnika graviranja dijamantnom iglom bila je specijalnost muranske proizvodnje koja je uspjela postići dovoljno čvrstu, kompaktnu, ali i prozirnu smjesu (Jović Gazić 2015: 51). Po cijeloj površini posude ucrtavali su se biljni i životinjski motivi, dok je predmet još bio mekan. Većina graviranih predmeta s nalazišta kod Gnalića danas je pokrivena tankom mutnom ljuskom koja je posljedica degradacije stakla (Petricioli 1970: 26). ${ }^{18}$

Stakleni predmeti bili su ukrašeni i tehnikom umetanja bijelih staklenih niti, odnosno filigrana. Filigransko staklo (tal. vetro a filigrana) razvilo se paralelno s primjenom pročišćenoga i izbjeljenoga kristalnog stakla, a izrađivalo se uz pomoć posebno pripremljenih staklenih štapića od bezbojnoga kristalnog stakla koji su sadržali nit bijele ili neke druge kontrastne boje (Jović Gazić 2015: 49). Na staklenim predmetima pronađenima na brodolomu kod otočića Gnalića ukrasi su izvedeni jednostavno u varijanti tzv. nitnoga stakla (tal. vetro a fili) u kojem su niti imale

16 I. Kelez (1970: 42) opisao je kako se reflektirajuća površina izrađivala pokrivanjem žive na kositrenom limu listom papira i pritiskivanjem staklene ploče nakon čega se list papira izvlačio, a kositreni lim sa živom stvarao reflektirajući amalgam. Opisana metoda, po njegovim riječima, izumljena je u 16. stoljeću u Nizozemskoj, ali su ju Mlečani brzo usvojili.

17 I. Lazar i H. Willmott (2006a: 72) donose dva različita uzorka uočena na ukrašenim prozorskim staklima. O srednjovjekovnoj tehnici puhanja u cilindar vidjeti Foy 2005.

18 Corning Museum of Glass, http://www.cmog.org/article/beyond-veniceglass-venetian-style-1500-1750, 03. 06. 2018. mercury is still present at the site. ${ }^{16}$ The finished mirrors appear to have been frameless and densely stacked next to each other, and canvas is mentioned as the material used in packaging (Lazar, Willmott 2006a: 68-69).

The rest of the glassware was made by the blowing technique, including free blowing, blowing into a mould, and optical blowing into a mould. Blowing caused a revolution in the making of glass, as objects could have had thin walls and been produced in a short time. The inside of the mould could have been shaped in various shapes, into which melted glass would then be blown. If the glass paste was formed in a mould, and additionally blown or twisted after being removed from the mould, the decoration was then made by so-called optical blowing in a mould (Davison 2006: 105; Fadić, Perović 2017: 55; Topić 2017: 48-52). Gnalić objects made by optical blowing are characterized by a honeycomb motif or a series of drop-shaped motifs reminiscent of a pinecone. The classic, i.e. original way of blowing into a mould, which forms a part of a glass vessel, is to blow a glass bubble into a mould of a special shape, without subsequent interventions (Fadić, Perović 2017: 44).

The window panes were made by a special technique of blowing and opening out a bubble of glass, and the glass paste would rotate to allow centrifugal forces to act and create a properly shaped glass plate. Glass with embossed rosette design was made by the optical blowing technique. ${ }^{17}$

For decorating better quality dishes, the technique of engraving with a diamond needle was a specialty of Murano production, that managed to achieve a sufficiently solid, compact, but also transparent paste (Jović Gazić 2015: 51). Plant and animal motifs were drawn all over the surface of the vessel while the object was still soft. Most of the engraved objects from the Gnalić site are covered with a thin opaque shell, which is a consequence of glass degradation (Petricioli 1970: 26). ${ }^{18}$

The glass objects were also decorated with opaque white trail, i.e. filigree. Filigree glass (vetro a filigrana) was developed in parallel with the application of purified and bleached crystal glass, and was made with the help of specially prepared glass canes of colourless crystal glass, which contained a trail of white or some other contrasting colour (Jović Gazić 2015: 49). On the glass objects found at the shipwreck of Gnalić, the decorations were made simply in the variant of the so-called trail glass (vetro a fili) in which the trails had a parallel arrangement, and in the so-called

16 I. Kelez (1970: 42) described how a reflective surface was made by covering mercury on tin sheet with a sheet of paper and pressing a glass plate, after which a sheet of paper was pulled out and tin sheet with mercury formed a reflective amalgam. The described method, he said, was invented in the $16^{\text {th }}$ century in the Netherlands, but was quickly adopted by the Venetians.

17 I. Lazar and H. Willmott (2006a: 72) bring two different patterns observed on decorated window panes. On the medieval technique of blowing into a cylinder, see Foy 2005

18 Corning Museum of Glass, http://www.cmog.org/article/beyond-veniceglass-venetian-style-1500-1750, 03. 06. 2018 
paralelan raspored te u varijanti tzv. retortnoga stakla (tal. vetro a retortoli/retorti) u kojem su niti tzv. mliječnoga stakla (tal. lattimo) bile različito isprepletene (Ratković Bukovčan 2013: 14-15).

lako je obrada i objava staklenih nalaza, realizirana u okviru projekta The Heritage of the Serenissima izrazito sadržajna i detaljna, valja napomenuti kako je u njoj iz razmatranja izostavljen već spomenuti Gasparettov rad o staklu s nalazišta kod Gnalića (Gasparetto 1976) koji sadrži najraniju detaljniju podjelu nalaza, uz mnoge zanimljive podatke i pretpostavke. U njemu se, na primjer, navode dokumenti iz Državnoga arhiva u Veneciji bliski vremenu u kojem se dogodio brodolom, a koji sadrže detaljne popise prevožene staklene robe. Na osnovi jednoga od njih Gasparetto (1976: 444-445) je određenim skupinama staklenih predmeta s Gnalića pokušao pripisati originalna mletačka imena. Gotti diversi i .... (nečitko) con boton baso mogli bi se odnositi na različite oblike čaša (A-1-a i A-1-b / S2a i S3a); inghistere comune i inghistere d'aqua cotta na određeni oblik luksuzne boce (A-2-a / S20); mastrapani na vrčeve s poklopcem (A-2-e / S8); bacili na zdjele (A-4-a / S15a i S15C); saliere na zdjelice za sol (A-4-b / S22), a vasi da fiori na male vaze (A3-a i A-3-b / S15c i S15a). ${ }^{19}$

Prema Gasparettovim riječima u istoj se polici navode i cesendelli da giesiola (viseće svjetiljke za svetišta), taze grose (veliki pladnjevi na nozi), tassine (mali pladnjevi na nozi), ferali grandi schieti (velike glatke svjetiljke), ferali grandi doradi (velike pozlaćene svjetiljke), orinali grossi (velike noćne posude) i orinali longi dopij (duge dvojne noćne posude), neidentificirani u brodskom teretu s Gnalića. Kao što je Gasparetto ispravno pretpostavio, i dalje postoji mogućnost njihovoga otkrivanja, što najbolje dokazuju tazze naknadno pronađene $u$ dvije varijante (S13 - S14).

Osim toga, predmeti kojih je na Gnaliću mnogo, kao što su npr. rui (okrugla prozorska stakla), quari (četvrtasta stakla za ogledala i prozore), ogledala 'da libretto' (prijeklopna ogledala) i paternostri (staklene perle), ne navode se u spomenutom dokumentu, ali je iz mnogih drugih dokumenata razvidno kako su se i oni često prevozili u velikim količinama kako prema istočnome, tako i prema zapadnome Mediteranu (Gasparetto 1976: 445-446). Terminologija mletačkih staklarskih proizvoda daleko je obimnija, ${ }^{20} \mathrm{pa} \mathrm{bi}$ se u tome smislu vrijedilo upustiti u još sadržajniju identifikaciju nalaza s Gnalića.

A. Gasparetto također je upozorio na kontinuiranu proizvodnju nekih oblika naslijeđenih iz gotičkoga vremena, poput čaša sa zvonolikom i čaša sa širokom polukuglastom čaškom (A-1-a i A-1-b / S2a i S3a), izrađivanih u Veneciji kako bi se zadovoljilo osmanlijsko tržište koje je usprkos sklonosti novitetima cijenilo tradicionalne proizvode (Gasparetto 1976: 446). Riječ je o predmetima koji su u dosadašnjem inventaru najbrojniji u skupini posuđa. ${ }^{21}$

\footnotetext{
19 Oznake koje počinju s A preuzete su iz Gasparettovog, a oznake koje počinju sa S iz teksta I. Lazar i H. Willmotta.

20 Usmeni podatak M. Bondioli.

21 I. Lazar i H. Willmott (2006a: 27, 30) navode 2552 primjerka čaša iz skupine s2a i 993 primjerka iz skupine S3a.
}

retort glass (vetro a retortoli/retorti) in which the trails of the so-called milk glass (lattimo) were differently intertwined (Ratković Bukovčan 2013: 14-15).

Although the processing and publication of glass finds, realized within the project The Heritage of the Serenissima, is extremely substantial and detailed, it should be noted that it omits Gasparetto's already mentioned work on glass from the Gnalić site (Gasparetto 1976), which contains the earliest more detailed categorization of finds, with many interesting data and assumptions. It cites, for example, documents from the State Archives in Venice, close to the time of the shipwreck, which contain detailed lists of transported glassware. On the basis of one of them, Gasparetto (1976: 444-445) tried to attribute original Venetian names to certain groups of glass objects from the Gnalic site. Gotti diversi and.... (illegible) con boton baso could refer to different shapes of goblets (A-1-a and A-1-b / S2a and S3a); inghistere comune and inghistere d'aqua cotta to a particular form of luxury bottle (A-2-a / S20); mastrapani to tankards with lid (A-2-e / S8); bacilli to bowls (A-4-a / S15a and S15C); saliere to salt bowls (A-4-b / S22), and vasi da fiori to small vases (A-3-a and A-3-b / S15c and S15a). ${ }^{19}$

According to Gasparetto, the same document also states cesendelli da giesiola (hanging lamps for shrines), taze grose (large footed tazzae), tassine (small footed tazzae), ferali grandi schieti (large smooth lamps), ferali grandi doradi (large gilded lamps), orinali grossi (large night vessels) and orinali longi dopij (long double night vessels), that have not been identified in the ship's cargo. As Gasparetto rightly assumed, there is still the possibility of their detection, as best proved by the tazzae, subsequently found in two variants (S13 - S14).

In addition, there are many items on Gnalić, such as rui (round window glass), quari (square glass for mirrors and windows), mirrors 'da libretto' (folding mirrors) and paternostri (glass beads), not mentioned in the cited document. It is evident, however, from many other documents, that they were often transported in large quantities to the eastern and western Mediterranean (Gasparetto 1976: 445-446). The terminology of Venetian glass products is far more extensive, ${ }^{20}$ so in that sense it would be worthwhile to engage in an even more meaningful identification of the Gnalić finds.

A. Gasparetto also pointed out the continuous production of some forms inherited from Gothic times, such as a bell-shaped goblet with a low hollow foot, and a plain goblet with a high hollow foot and hemispherical bowl (A-1-a and A-1-b / S2a and S3a), made in Venice to satisfy the Ottoman market which, despite its propensity for novelty, valued traditional products (Gasparetto 1976: 446). These are the items that, up to now, are the most numerous in the inventory of vessel glass. ${ }^{21}$

\footnotetext{
19 Labels beginning with A are taken from Gasparetto, and labels beginning with $\mathrm{S}$ from the text of I. Lazar and H. Willmott.

20 Personal communication M. Bondioli.

21 I. Lazar and H. Willmott (2006a: 27, 30) cite 2552 specimens of goblets from group S2a and 993 specimens from group S3a.
} 
$\mathrm{K}$ tome, u repertoaru mletačke robe po njegovim se riječima nalaze i predmeti koji stilski ne pripadaju izvornim mletačkim proizvodima, ali se izrađuju kako bi se Osmanlijama ponudilo predmete nalik njihovim vlastitima, ali bitno veće kvalitete (Gasparetto 1976: 428-429). Sukladno tome, Gasparetto je pretpostavio kako je staklena roba bila u cijelosti nabavljena u Veneciji, tj. Muranu s namjerom da se proda na carigradskome tržištu. U knjizi Irene Lazar i Hugha Willmotta za neke ne-europske oblike stakla također je izrečena ta pretpostavka, iako se, kao što je rečeno, ostavlja i mogućnost njihovoga islamskog podrijetla (Lazar, Willmott 2006a: 76).

Caroline Jackson analizirala je više od 200 uzoraka stakla ne bi li se sveobuhvatan opis staklenoga inventara s brodoloma nadopunio novim mogućim pojašnjenjima. Kemijska analiza provedena je na fakultetu Royal Holloway Sveučilišta u Londonu upotrebom ICP-AES - induktivno spregnute atomske emisijske spektroskopije (eng. Inductively Coupled Plasma Atomic Emission Spectroscopy), analitičke metode kojom se određuju elementi u tragovima. Cilj analize bio je otkriti moguće podrijetlo i potencijalne radionice predmeta, razvrstavajući staklo prema tipologiji na staklene posude i ravno staklo zbog različite vještine izrade. Na osnovi kemijske analize vidljiv je ujednačeni sastav stakla vitrum blanchum od natrijevoga karbonata (soda), kalcijevoga oksida (živo vapno) i silikatnoga dioksida (kvarcni pijesak), s formulom $\mathrm{Na}_{2} \mathrm{CO}_{3}-\mathrm{CaO}-\mathrm{SiO}_{2}$. Sastav stakla ukazuje na nepostojanje razlike između grupa različitih funkcija. Sve te sličnosti, usprkos manjim neujednačenostima, ukazuju na način proizvodnje i na odabir sirovinskoga materijala, ali ne i na mjesto produkcije (Jackson 2006: 88; 2009: 137).

Prema sastavu stakla vidljivo je da je staklo bilo proizvedeno od biljnoga pepela bogatoga sodom dobivenoga vjerojatno od biljaka iz roda Salicornia i Salsola kali, od alkalija koje su vjerojatno uvezene iz Sirije ili Egipta i od lokalnoga pijeska, što objašnjava sličnost sastava različitih stilskih skupina. Pijesak je dolazio iz rijeke Ticino, sa širega područja Verone i s područja Venecije. Unutar sastava stakla nalazi se željezov oksid $\left(\mathrm{Fe}_{2} \mathrm{O}_{3}\right)$ i aluminijev oksid $\left(\mathrm{Al}_{2} \mathrm{O}_{3}\right)$ koji potječu iz kvarcnoga pijeska. Odnos dvaju oksida minimalno se razlikuje u staklenim predmetima, vjerojatno radi različitoga omjera pijeska tijekom stvaranja staklene smjese. U uzorcima su promatrane koncentracija cirkonija ( $\mathrm{Zr}$ ) i barija (Ba), elemenata u tragovima koji su povezani s kvarcnim pijeskom i koji mogu poslužiti kao mogući indikatori mjesta proizvodnje. S obzirom na sastav stakla, koji je prilično ujednačen, koncentracije cirkonija i barija pokazuju nejednaku sliku te upućuju na mogućnost različitih radionica unutar širega područja (Jackson 2006:8890; 2009: 140). Prema elementima u tragovima koji se nalaze u pijesku moguće je utvrditi razlike u proizvodnim centrima. Primjerice, ukoliko je koncentracija cirkonija visoka (do 120 ppm) staklo dolazi iz radionica koje proizvode a la façon de Venise (na mletački način), a u protivnome s područja Venecije (između 20 i 40 ppm). Zbog toga Caroline Jackson smatra da se staklo s niskom koncentracijom cirkonija, poput
In addition, according to Gasparetto, the repertoire of Venetian goods includes items that do not stylistically belong to the original Venetian products, but are made to offer the Ottomans items similar to their own, but of much higher quality (Gasparetto 1976: 428-429). Accordingly, Gasparetto assumed that the glass goods were procured entirely in Venice, i.e. Murano, with the intention of being sold on the Constantinople market. In the book by Irena Lazar and Hugh Willmott for some non-European forms of glass, this is also assumed, although, as has been said, the possibility of their Islamic origin is also considered (Lazar, Willmott 2006a: 76).

Caroline Jackson analysed over 200 glass samples in order to supplement the comprehensive description of the glass inventory with new possible clarifications. Chemical analysis was performed at Royal Holloway University in London, using Inductively Coupled Plasma Atomic Emission Spectroscopy (ICP-AES), an analytical method used to determine trace elements. The aim of the analysis was to discover the possible origin and potential workshops, classifying glass according to the typology into glass vessels and flat glass, due to different manufacturing skills needed for their production. Based on the chemical analysis, the composition of vitrum blanchum glass, made of sodium carbonate (soda), calcium oxide (quicklime) and silicate dioxide (quartz sand), with the formula $\mathrm{Na}_{2} \mathrm{CO}_{3}-\mathrm{CaO}-\mathrm{SiO}_{2}$, was determined to be quite uniform. The composition of the glass indicates that there is no difference between groups of different functions. All these similarities, despite minor inconsistencies, indicate the method of production and the choice of raw material, but not the place of production (Jackson 2006: 88; 2009: 137).

According to the composition of glass, it was produced of soda-rich plant ash, probably obtained from plants of the genus Salicornia and Salsola kali, from alkalis probably imported from Syria or Egypt and from local sand, which explains the similarity of the composition of different stylistic groups. The sand came from the Ticino River, from the wider area of Verona and from the area of Venice. Inside the composition of glass, there is iron oxide $\left(\mathrm{Fe}_{2} \mathrm{O}_{3}\right)$ and aluminium oxide $\left(\mathrm{Al}_{2} \mathrm{O}_{3}\right)$, which originate from quartz sand. The ratio of the two oxides differs minimally in glass objects, probably due to the different ratio of sand during the formation of the glass paste. The concentrations of zirconium $(\mathrm{Zr})$ and barium $(\mathrm{Ba})$, trace elements associated with quartz sand which can serve as possible indicators of the production site, were observed in the samples. Given the composition of the glass, which is fairly uniform, the concentrations of zirconium and barium show an unequal picture and suggest the possibility of different workshops within a wider area (Jackson 2006: 88-90; 2009: 140). According to the trace elements found in the sand, it is possible to postulate different production centres. For 


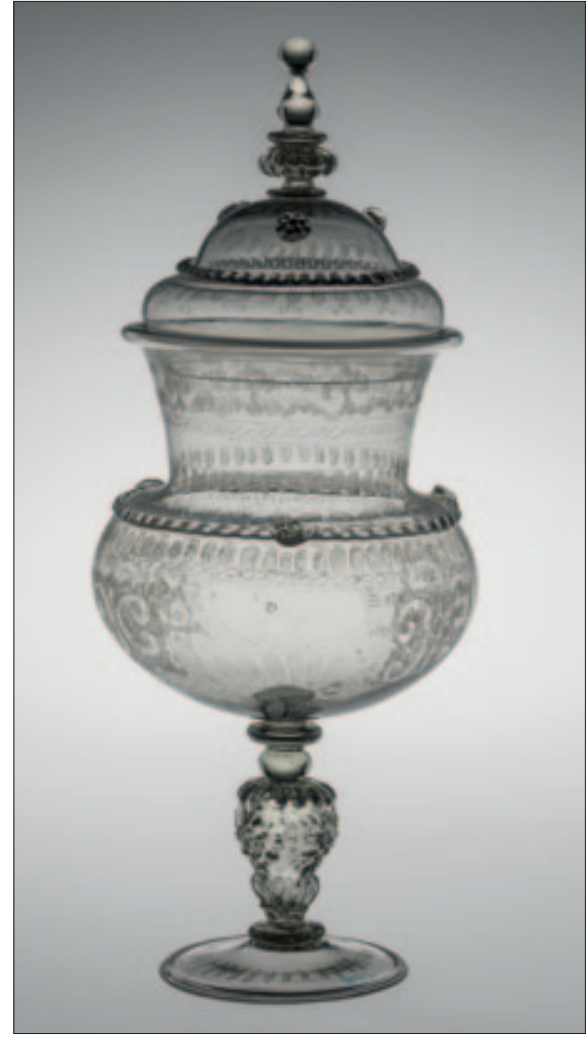

SI. 11 Čaša na stalku s poklopcem (Corning Museum of Glass, https://www.cmog. org/artwork/covered-goblet-vasenpokal)

Fig. 11 Glass on a stand with a lid (Corning Museum of Glass, https://www.cmog.org/ artwork/covered-goblet-vasenpokal)

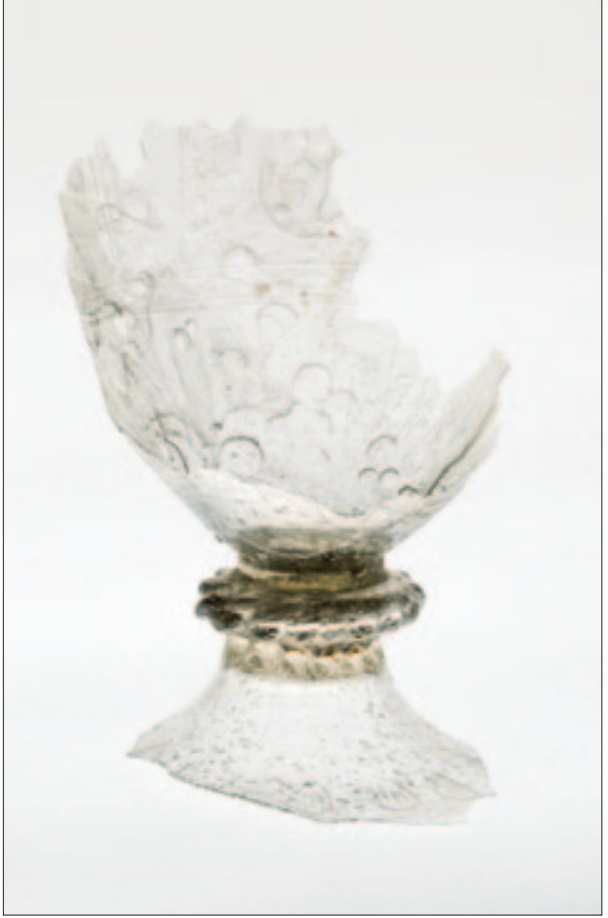

SI. 12 Ulomak male gravirane vaze, pogrešno interpretiran kao ulomak čaše na nožici (snimio: I. Asić; prema: Filep 2013: 144)

Fig. 12 Fragment of a small engraved vase, misinterpreted as a fragment of a glass on a leg (photo by: I. Asić; after: Filep 2013: 144)

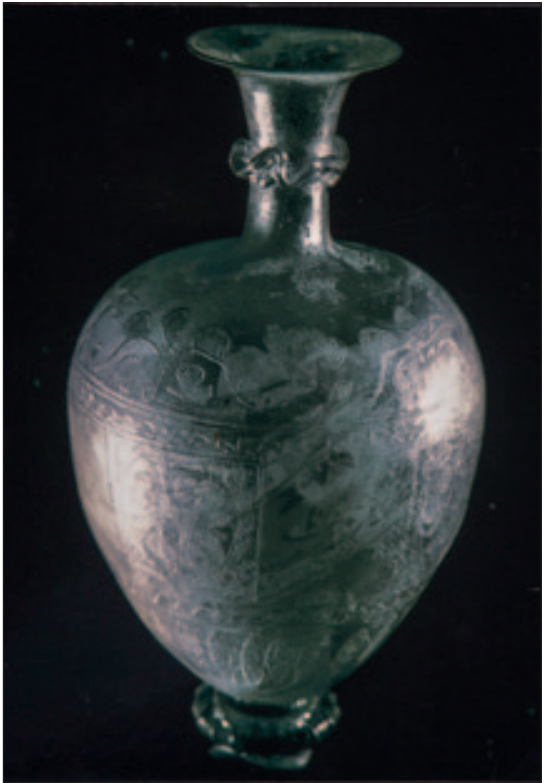

SI. 13 Mala gravirana vaza (ZMB - G 51) ukradena 1970. godine, 1967. (izvor: Arhiva Zavičajnoga muzeja Biograd na Moru)

Fig. 13 Small engraved vase (ZMB - G 51) stolen in 1970, 1967 (source: Archive of the Homeland Museum Biograd na Moru) stakla s Gnalića (niže od 40 ppm), treba pripisati staklenim proizvodima s prostora Venecije ili s ostaloga prostora Italije (Jackson 2006: 92; 2009: 140).

\section{NOVA ZAPAŽANJA I NALAZI}

Kao što je spomenuto u uvodnome poglavlju, prilikom pripremanja izložbe u Hrvatskome povijesnom muzeju 2013. godine došlo se do nekoliko novih spoznaja o mogućoj identifikaciji fragmentiranih staklenih predmeta. Ana Filep argumentirano je upozorila na mogućnost da su čaše s nožicom ukrašenom nodusom s motivom lavljih glava iz skupine S7 povezane s kupolastim dekoriranim poklopcima s prihvatom, a koje su I. Lazar i H. Willmott pridružili vazama iz skupine S15c (Lazar, Willmott 2006a: 51, 83, 123; Filep 2013: 59-60, 144). Cjeloviti primjerci nalaze se na web stranici Muzeja stakla u Corningu (sl. 11).22

Osim toga, tijekom rada na inventaru uočeno je da ulomci niskih nožica s prstenastim zadebljanjem koje dijeli podnožje od tijela posude (sl. 12), objavljeni u radu I. Lazar i H. Willmota u skupini čaša S5e, u stvari pripadaju malim graviranim vazama iz skupine S15a (Filep 2013: 59; Filep et al. 2013: 143-144). Time se broj pronađenih ulomaka malih

22 Corning Museum of Glass, https://www.cmog.org/artwork/covered-gobletvasenpokal. example, if the concentration of zirconium is high (up to 120 ppm), the glass comes from workshops that produce $a$ la façon de Venise (in the Venetian way), and otherwise from the area of Venice (between 20 and 40 ppm). Therefore, Caroline Jackson believes that glass with a low concentration of zirconium, such as glass from Gnalić (lower than 40 ppm), should be attributed to glass products from Venice or the rest of Italy (Jackson 2006: 92; 2009: 140).

\section{NEW OBSERVATIONS AND FINDS}

As mentioned in the introductory chapter, during the preparation of the 2013 exhibition at the Croatian History Museum, some new insights were gained about the possible identification of fragmented glass objects. Ana Filep argued that the goblets with a lion-head stem from the S7 group were connected to domed decorated lids with a receptacle, which I. Lazar and $\mathrm{H}$. Willmott published with the vases from the S15c group (Lazar, Willmott 2006a: 51, 83, 123; Filep 2013:59-60,144). Complete specimens can be found at the Corning Glass Museum website (Fig. 11). ${ }^{22}$

22 Corning Museum of Glass, https://www.cmog.org/artwork/covered-gobletvasenpokal. 


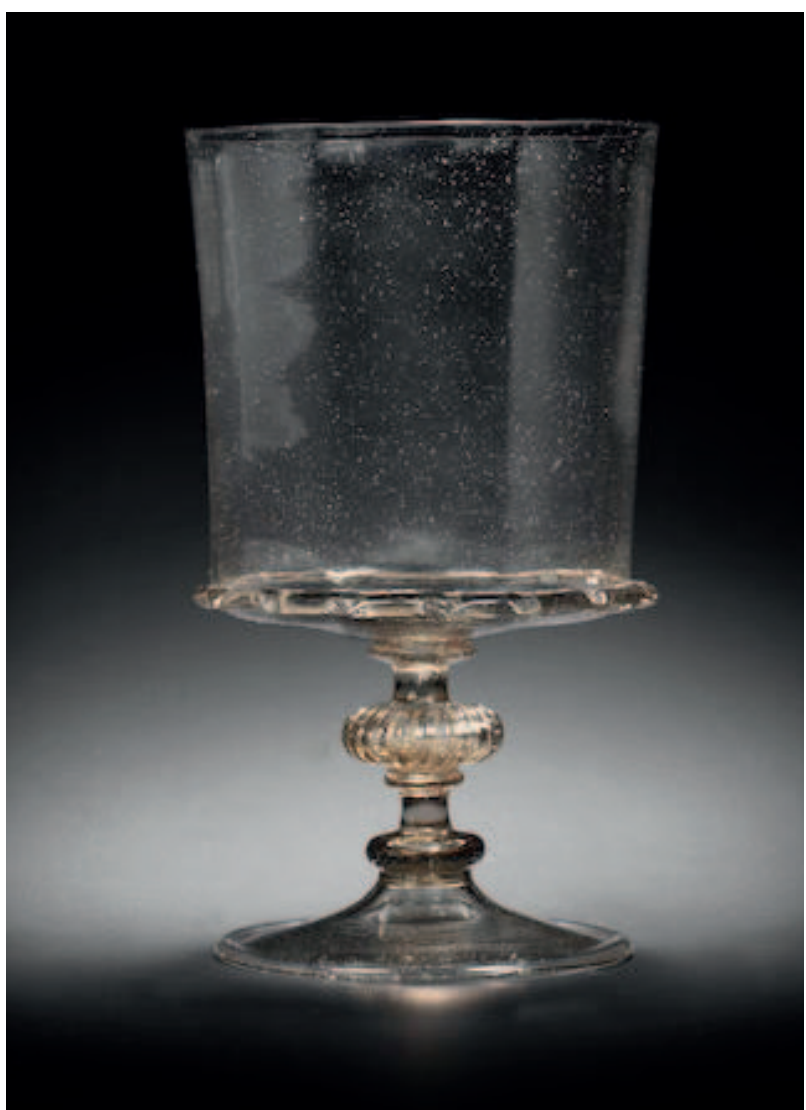

SI. 14 Cjelovita čaša s nožicom koja se odlikuje narebrenim i jednostavnim spljoštenim nodusima i ravnim podnožjem (Bonhams, https://www.bonhams.com/auctions $/ 22021 /$ lot $/ 4 /$ ?category=list\&length $=100 \&$ page $=1$ )

Fig. 14 Complete glass with a leg characterized by ribbed and simple flattened nodules and a flat base (Bonhams, https:// www.bonhams.com/auctions/22021/lot/4/?category=list \&length $=100 \&$ page $=1$ )

graviranih vaza popeo na dvanaest. Jedini gotovo cjelovit primjerak poznat je, na žalost, samo s fotografije (Petricioli 1970: sl. 39; Gasparetto 1976: sl. 13; Lazar, Willmott 2006a: 49; Filep 2013: sl. 5), jer je dana 11. lipnja 1970. otuđen iz muzejskoga prizemlja prilikom postavljanja izložbe (Filep et al. 2013: 144) (sl. 13).

Nakon što je tiskan katalog izložbe 2013. godine, pojavile su se nove interpretacija pojedinih predmeta iz staklenoga inventara. Čaše s narebrenim i jednostavnim plosnatim nodusom na nožici (S5d) (Lazar, Willmott 2006a: 34, 80) moguće je rekonstruirati zahvaljujući cjelovito očuvanoj čaši prikazanoj na web stranici međunarodne aukcijske kuće Bonhams (sl. 14). ${ }^{23}$ Naravno, sa zaključcima ne treba žuriti i isključiti ostale mogućnosti, pa ovaj slučaj može poslužiti kao primjer potrebe ispitivanja svih mogućih novijih interpretacija.

Sljedeći primjer je dekorirana čaša s narebrenim plosnatim nodusom na nožici (S5c), od koje su se sačuvali podnožje, nožica i fragmenti čaške (Lazar, Willmott 2006a: 34, 80; Filep et al. 2013: 137). Podnožje i čaška ukrašeni su moti-

23 Bonhams, http://www.bonhams.com/auctions/22021/lot/4/?category=list \&length $=100$ \&page $=1$.

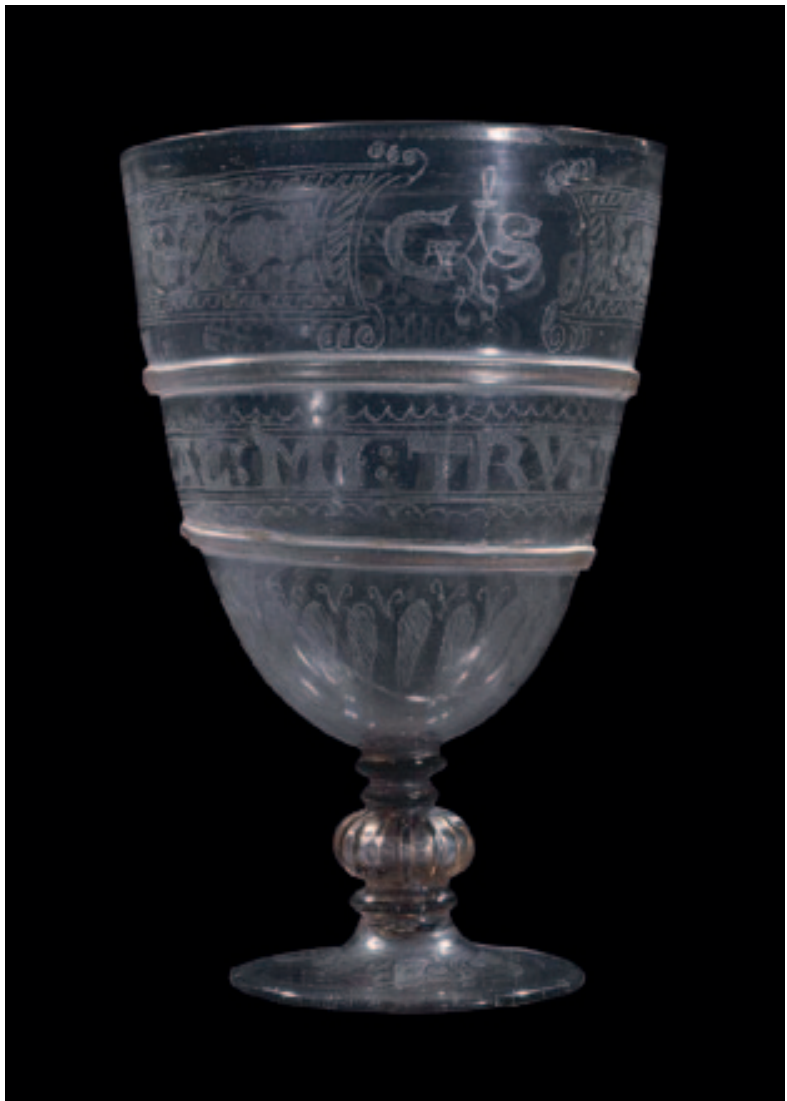

SI. 15 Čaša na nožici koju je izradio Giacomo (Jacopo) Verzelini, posljednja četvrtina 16. stoljeća (The British Museum, https://www.britishmuseum.org/collection/ object/H_1895-0603-17)

Fig. 15 A glass on a leg made by Giacomo (Jacopo) Verzelini, the last quarter of the 16th century (The British Museum, https://www.britishmuseum.org/collection/ object/H_1895-0603-17)

In addition, during the work on the inventory, it was noticed that the fragments of low stems with an annular thickening that separates the foot from the bowl of the vessel (Fig. 12), published by I. Lazar and $\mathrm{H}$. Willmot in the group of goblets S5e, actually belong to small vases decorated with engraving, from the group S15a (Filep 2013: 59; Filep et al. 2013: 143-144). Thus, the number of recovered fragments of small engraved vases rose to twelve. Unfortunately, the only almost complete copy is known just from the photograph (Petricioli 1970: Fig. 39; Gasparetto 1976: Fig. 13; Lazar, Willmott 2006a: 49; Filep 2013: Fig. 5), because it was stolen from the museum ground floor on 11 June 1970, during the setup of the exhibition (Filep et al. 2013: 144) (Fig. 13).

After the 2013 catalogue of the exhibition was printed, new interpretations of individual items from the glass inventory have been developed. Goblets with ribbed and plain flattened knop (S5d) (Lazar, Willmott 2006a: 34, 80) could have been reconstructed thanks to the completely preserved cup shown on the website of the international auction house Bonhams (Fig. 14). ${ }^{23}$ Of course, one should

23 Bonhams, http://www.bonhams.com/auctions/22021/lot/4/?category=list \&length=100\&page $=1$ 


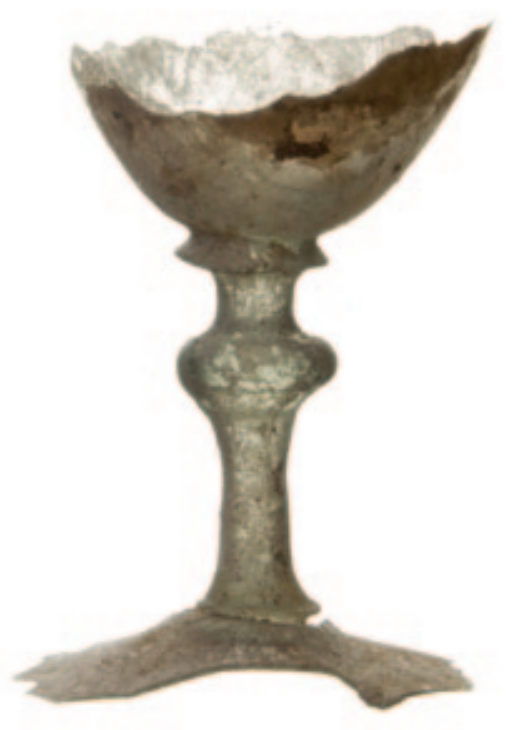

a

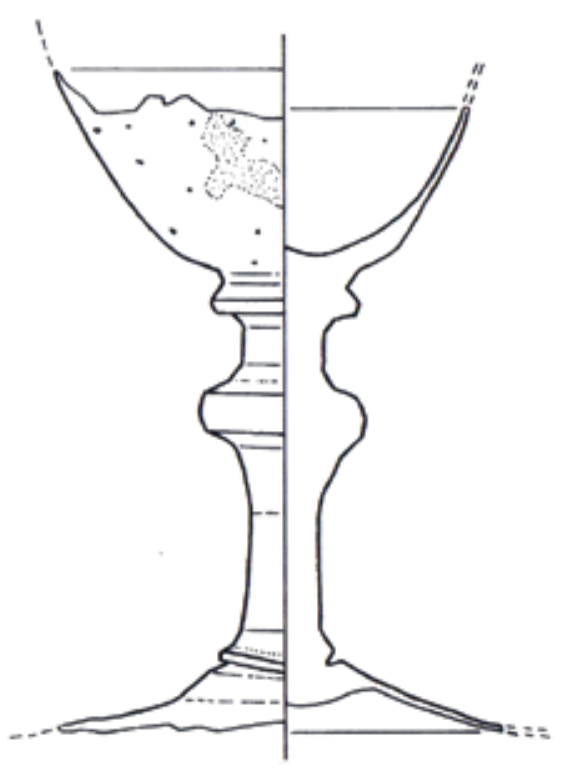

b

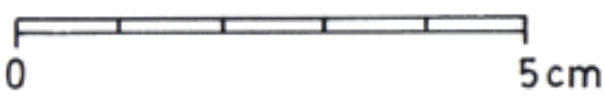

SI. 16 a-b Čaša s jednostavnim plosnatim zadebljanjem (nodusom) na visokoj nožici, GN.2012.1152 (izvor: Arhiva projekta Brodolom kod Gnalića - ogledalo renesansnog svijeta; crtež: Z. Bakić)

Fig. 16 a-b Glass with a simple flat thickening (nodus) on a high leg, GN.2012.1152 (source: Archive of the Shipwreck near Gnalić project - a mirror of the Renaissance world; drawing by: Z. Bakić)

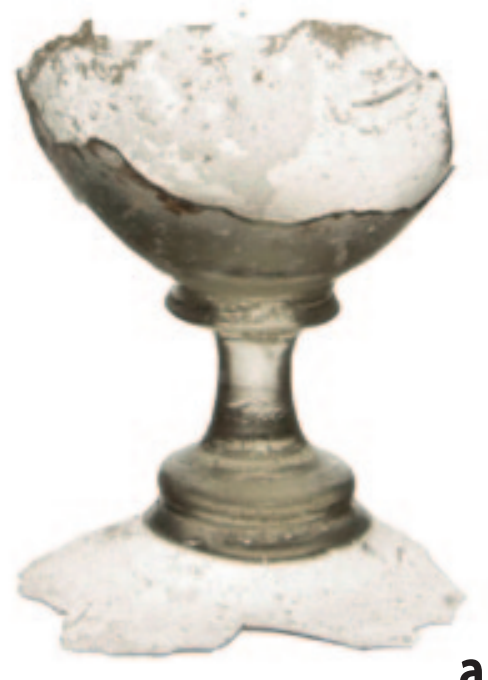

a

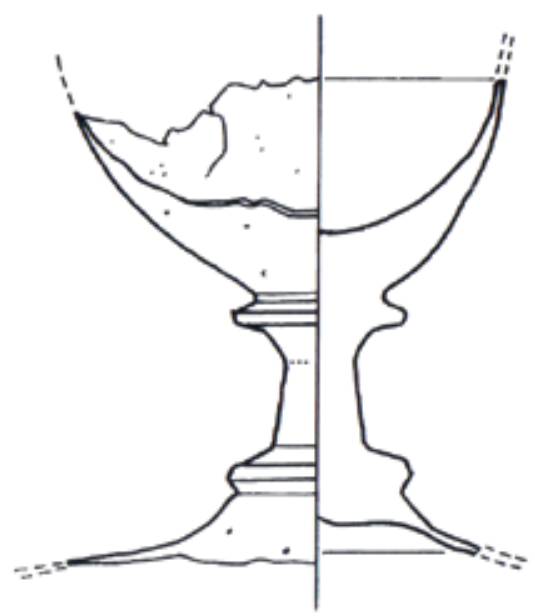

b

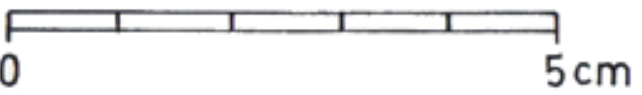

SI. 17 a-b Čaša s jednostavnom niskom nožicom, GN.2012.1151 (izvor: Arhiva projekta Brodolom kod Gnalića - ogledalo renesansnog svijeta; crtež: Z. Bakić)

Fig. 17 a-b Glass with a simple low leg, GN.2012.1151 (source: Archive of the Shipwreck near Gnalić project - a mirror of the Renaissance world; drawing by: Z. Bakić) 
vima listova izvedenima graviranjem dijamantnom iglom. Dekorirana čaška nije se očuvala u cijelosti, a podržava ju nožica koja stoji na dekoriranome kružnom i blago povišenome podnožju, bez zadebljanoga ruba. Nožica se odlikuje narebrenim, plosnatim, prstenasto profiliranim nodusom u središnjem dijelu. Zanimljivo je da ovaj primjerak podsjeća na čaše koje je tada izrađivao Giacomo (Jacopo) Verzelini. Cjelovita čaša nalazi se na web stranici Britanskoga muzeja u Londonu (sl. 15). ${ }^{24}$

Poznati staklar Giacomo (Jacopo) Verzelini došao je u Englesku iz Venecije, a engleska kraljevska obitelji dodijelila mu je pravo izrađivanja stakla. Njegova djela vežu se uz dekorirano staklo poput čaše nastale 1583. godine koju je izradio a la façon de Venise (na mletački način). Mnogi predmeti koje je dao izraditi ukrašeni su graviranjem dijamantnom iglom, a ukrasio ih je Anthony de Lysle koji je došao iz Francuske. Kružna čaška uglavnom je bila ukrašena biljnim motivima i osnovnom misaonom rečenicom IN GOD IS AL MI TRVST (u Bogu je sva moja vjera) (Filep 2013: 59-60). ${ }^{25}$ Dekoracija koja se pojavljuje na čaši tipa Verzelini slična je onoj koja se javlja i na dekoriranoj čaši s malim nodusom u obliku lavlje glave na nožici (S7a). Čini se stoga da su dvije bogato ukrašene čaše (S5c i S7a) moguća ostavština umijeća Giacoma (Jacopa) Verzelinija u Veneciji.

$\mathrm{Na}$ web stranicama Muzeja stakla u Corningu, Muzeja Rijks u Amsterdamu i Muzeja Viktorije i Alberta u Londonu mogu se vidjeti cjeloviti primjeri čaša i pladnjeva (podnosa) koji imaju ukrašene nožice nodusom s motivom lavljih glava iznad kojih se nalazi narebreni prsten. Čaška je bila široko izvedena na razne načine. Gnalićki primjerci pod oznakom S7d, s istim karakteristikama nožice, nemaju očuvanu čašku. Čaše s nodusom u obliku lavljih glava na nožici mogle su imati čaške raznih oblika, što se može vidjeti na primjercima prikazanim na web stranicama gore spomenutih institucija. Svojim oblikom, primjerci čaški podsjećaju na pladnjeve (podnose) koji su bili široko izvedeni na razne načine, a služili su za ispijanje vina, držanje slatkiša ili voća. ${ }^{26}$ Prikazani predmeti ukazuju na činjenicu da cjelovit izgled čaša ili pladnjeva (podnosa) nije moguće, bez zadrške, rekonstruirati u cijelosti. Zbog krhkosti i fragmentiranosti stakla potrebno je ispitati sve mogućnosti interpretacije.

Repertoar staklenih predmeta pronađenih na brodolomu kod otočića Gnalića upotpunjen je novim nalazima koji su se pojavili tijekom istraživačkih kampanja od 2012. do 2020. Svi su predmeti slični nalazima iz prijašnjih istraživanja, a razlike se zapažaju u njihovim dimenzijama, oblicima, kao i ukrasima i načinu ukrašavanja. U skupini staklenoga posuđa uočeni su novi oblici čaša na nožici, poklopac i vratovi boca te obojeno staklo unutar kojega su plave boce s novim dimenzijama dna. Skupina neidentificiranih pred-

24 The British Museum, https://www.britishmuseum.org/collection/ object/H_1895-0603-17.

25 Corning Museum of Glass, http://www.cmog.org/artwork/goblet-236.

26 Corning Museum of Glass, http://www.cmog.org/artwork/drinkingtazza?image=0; Rijksmuseum, https://www.rijksmuseum.nl/en/collection/ BK-NM-774; Victoria and Albert Museum, http://collections.vam.ac.uk/item/ 01513/tazza/; Corning Museum of Glass, http://www.cmog.org/glass-dictionary/tazza. not rush to conclusions and exclude other reconstruction possibilities, so this case can serve as an example of the need to examine all possible interpretations.

Another example is a goblet with a ribbed flattened knob and engraved decoration (S5c), of which the foot, stem and bowl fragments have been preserved (Lazar, Willmott 2006a: 34, 80; Filep et al. 2013: 137). The foot and the bowl are decorated with leaf motifs, engraved with a diamond needle. The decorated bowl has not been entirely preserved, and is supported by a stem, standing on a decorated circular and slightly elevated foot, without a thickened edge. The stem is characterized by a ribbed, flat, annularly profiled nodule, situated in the central part. Interestingly, this specimen is reminiscent of the glasses made by Giacomo (Jacopo) Verzelini at that time. The complete goblet may be seen on the website of the British Museum in London (Fig. 15). ${ }^{24}$

The famous glassmaker Giacomo (Jacopo) Verzelini came from Venice to England and the English royal family granted him the right to produce glass objects. His works were associated with decorated glass, such as a goblet created in 1583, which he made a la façon de Venise (in the Venetian way). Many of the items he made were decorated with a diamond needle engraving, executed by the French artisan Anthony de Lysle. The circular bowl was decorated with plant motifs and the sentence IN GOD IS AL MI TRVST (in God is all my trust) (Filep 2013: 59-60). ${ }^{25}$ The decoration that appears on a Verzelini-type goblet is similar to that which appears on goblets with a small lion mask stem and engraved decoration (S7a). It seems, therefore, that two richly decorated goblets ( $\mathrm{S} 5 \mathrm{C}$ and $\mathrm{S} 7 \mathrm{a}$ ) are a possible legacy of the art of Giacomo (Jacopo) Verzelini in Venice.

On the websites of the Corning Museum of Glass, the Rijks Museum in Amsterdam, and the Victoria and Albert Museum in London, complete examples of goblets and tazzae that have lion-head stems with ribbed rings above may be seen. The bowls are wide and made in various ways. Gnalić specimens marked S7d, with the same characteristics of the stem, do not have a preserved bowl. Goblets with a lion-shaped nodule on the stem could have had bowls of various shapes, as can be seen in the objects shown on the websites of the above-mentioned institutions. In their shape, the bowls are reminiscent of tazzae that were widely made in various ways, and were used for drinking wine, or holding sweets or fruit. ${ }^{26}$ The presented objects indicate the fact that the complete goblets or tazzae cannot be, with certainty, completely reconstructed. Due to the fragility and fragmentation of the glass, it is necessary to examine all the possible interpretations.

24 The British Museum, https://www.britishmuseum.org/collection/ object/H_1895-0603-17.

25 Corning Museum of Glass, http://www.cmog.org/artwork/goblet-236.

26 Corning Museum of Glass, http://www.cmog.org/artwork/drinkingtazza?image=0; Rijksmuseum, https://www.rijksmuseum.nl/en/collection/ BK-NM-774; Victoria and Albert Museum, http://collections.vam.ac.uk/item/ 01513/tazza/; Corning Museum of Glass, http://www.cmog.org/glass-dictionary/tazza. 
meta uvećana je za tri staklena obojena predmeta. Predmeti su predstavljeni onim redom kojim slijede u objavi staklenih nalaza Irene Lazar i Hugha Willmotta.
The repertoire of glass objects found at the shipwreck of Gnalić has been supplemented with new finds, recovered during research campaigns from 2012 to 2020 . All objects are

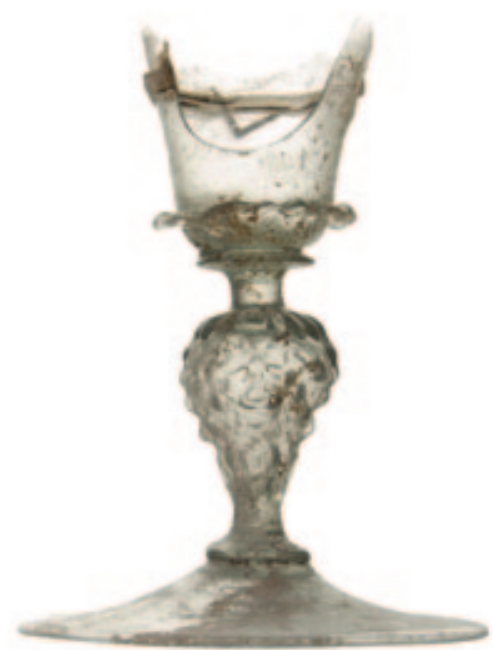

a
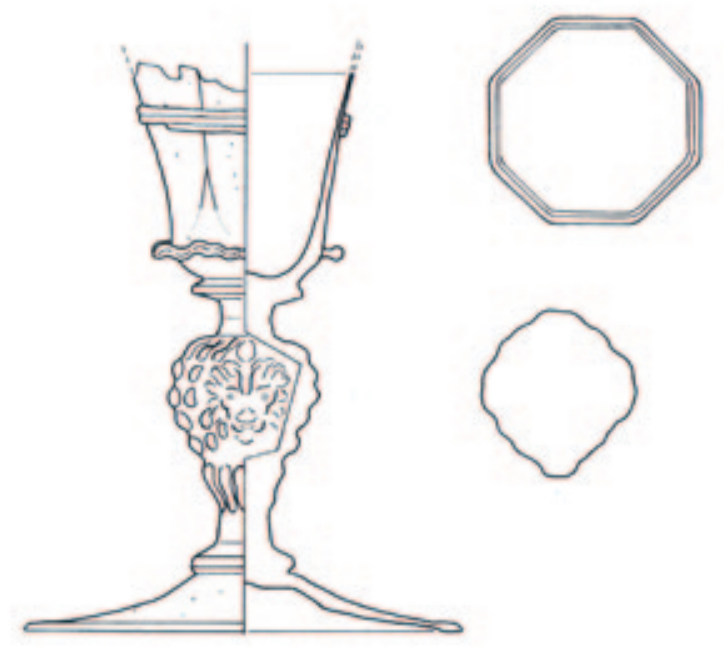

b

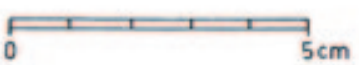

SI. 18 a-b Čaša sa zadebljanjem (nodusom) s motivom lavljih glava na nožici i ukrašenom čaškom osmerokutnog oblika, GN.2012.1149 (izvor: Arhiva projekta Brodolom kod Gnalića - ogledalo renesansnog svijeta; crtež: Z. Bakić)

Fig. $18 a-b$ Glass with a thickening (nodus) with a motif of lion heads on a leg and a decorated octagonal cup, GN.2012.1149 (source: Archive of the Shipwreck near Gnalić project - a mirror of the Renaissance world; drawing by: Z. Bakić)

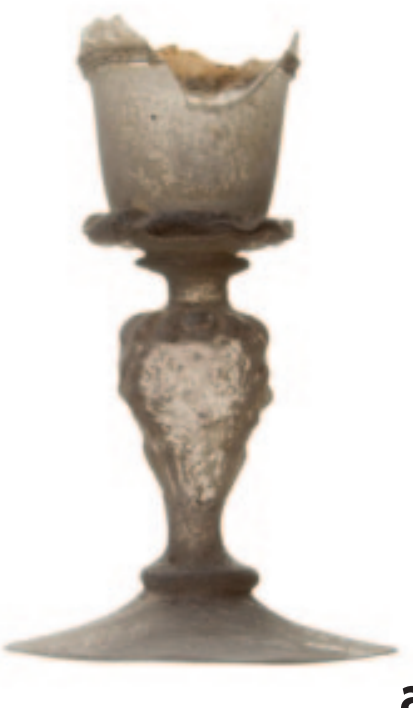

a
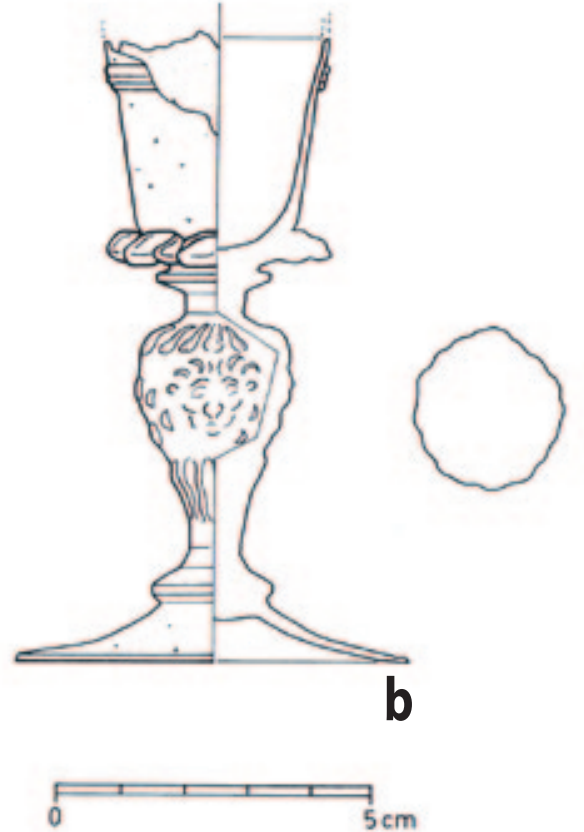

SI. 19 a-b Čaša sa zadebljanjem (nodusom) s motivom lavljih glava na nožici i ukrašenom čaškom kružnog oblika, GN.2012.1140 (izvor: Arhiva projekta Brodolom kod Gnalića - ogledalo renesansnog svijeta; crtež: Z. Bakić)

Fig. 19 a-b A glass with a thickening (nodus) with a motif of lion heads on a leg and a decorated circular cup, GN.2012.1140 (source: Archive of the Shipwreck near Gnalić project - a mirror of the Renaissance world; drawing by: Z. Bakić) 


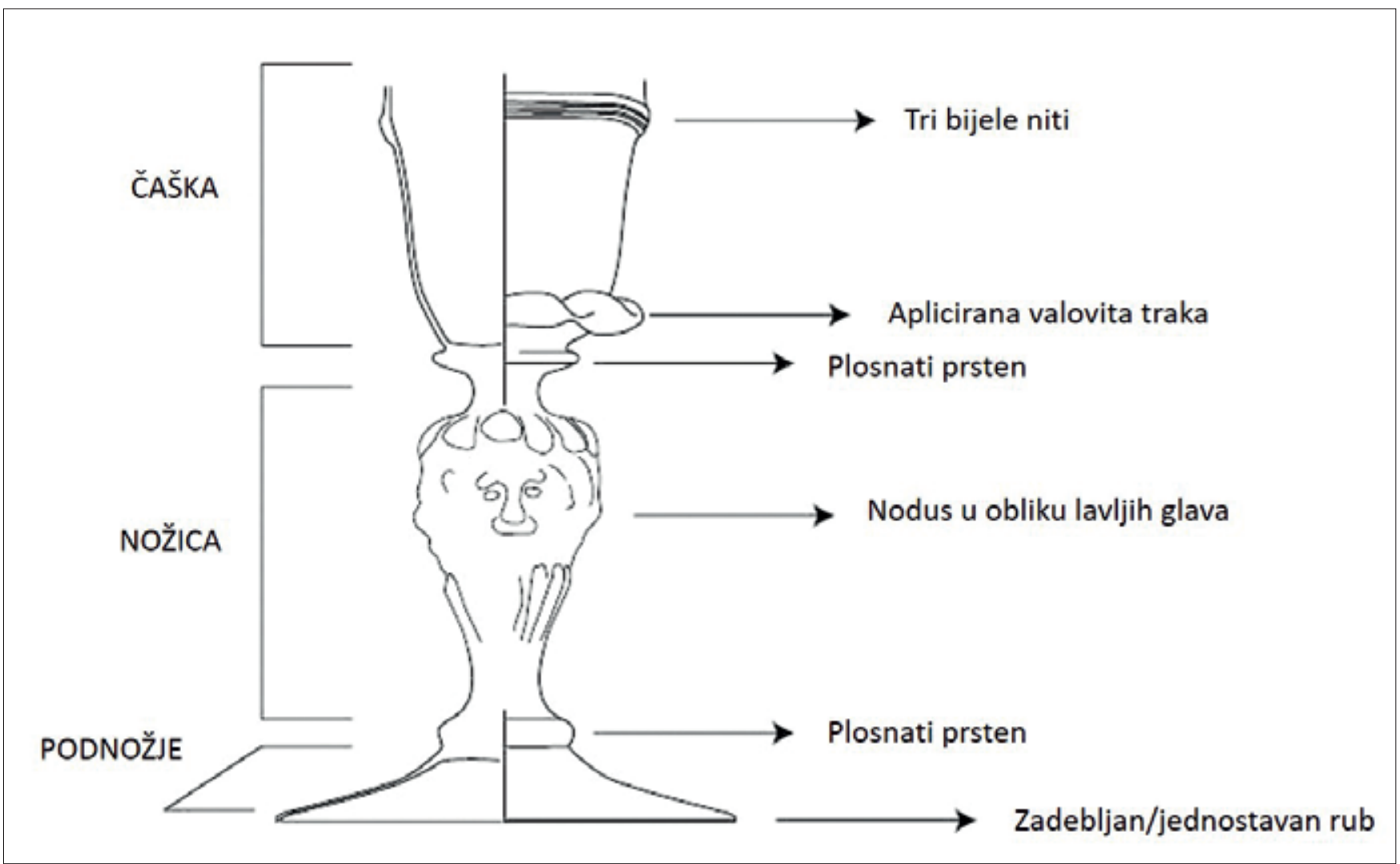

SI. 20 Dijelovi čaše ukrašene lavljim glavama (izradila: I. Šelendić) Fig. 20 Parts of a glass decorated with lion's heads (made by: I. Šelendić)

Među novim tipovima čaša ističu se tri visoke nožice $s$ jednostavnim plosnatim nodusom (kat. br. 1; sl. 16a-b) i jedna niska jednostavna nožica (kat. br. 2; sl. 17a-b). Oba tipa nožica podržavaju izdignutu čašku koja je spojena pomoću plosnatih prstena ispod čaške. Nožice s nodusom u obliku lavljih glava, nastale puhanjem u kalup, podržavale su dvije nove inačice čaške, osmerokutnu (kat. br. 3; sl. 18a-b) i jednostavnu kružnu (kat. br. 4; sl. 19a-b). Obje predstavljaju novi tip dekoriranih čaša s tri horizontalne bijele niti i jednom valovitom staklenom trakom na donjem dijelu čaške. Čaše s nodusom u obliku lavljih glava odlikuju se podnožjem povezanim s nožicom iz koje se dalje razvija čaška (sl. 20). Nožica je bogato reljefno dekorirana dvjema lavljim glavama povezanima u jednu cjelinu pomoću plastično oblikovanih girlandi. Na gornjoj i donjoj strani nožice nalaze se dva plosnata prstena povezana s čaškom i podnožjem.

U stolno posuđe ubrajaju se stakleni poklopci kojih se pripadnost često ne može utvrditi. U ovu kategoriju ubraja se i novo otkriveni ukrašeni poklopac (kat. br. 5; sl. 21a-b). Motivi listova na oplošju izvedeni su graviranjem dijamantnom iglom. U središnjem dijelu nalazi se prihvat u obliku plosnatoga prstena. Međutim, stakleni predmet nije očuvan u cijelosti. Visina očuvanoga ulomka iznosi $2 \mathrm{~cm}$, a promjer otvora $5 \mathrm{~cm}$. U novim istraživanjima pronađen je samo jedan primjerak.

U kategoriji spremnika nalaze se boce od kojih su se nerijetko očuvali vrat i/ili podnožje. Njihov izgled može se similar to the finds from previous research, and differences are observed in their dimensions, shapes and decorations. In the group of glassware there are new shapes of goblets on stems, a lid and bottle necks, as well as coloured glass which encompasses blue bottles with bases of different dimensions. The group of unidentified objects was enlarged by three coloured glass objects. The items are presented in the same order as in the book published by Irena Lazar and Hugh Willmott.

Among the new types of goblets, three high stems with a simple flat knob (cat. no. 1; Fig. 16a-b) and one low simple stem (cat. no. 2; Fig. 17a-b) stand out. Both types of stems support a raised bowl which is connected to the stem by flat rings. Lion-head stems, created by blowing into a mould, supported two new versions of the bowl, octagonal (cat. no. 3; Fig. 18a-b) and a simple circular (cat. no. 4; Fig. 19a-b). Both represent a new type of decorated goblet with three horizontal white trails and one wavy glass trail at the bottom of the bowl. Goblets with lion-head stems are characterized by a foot connected to the stem, from which the bowl is raised (Fig. 20). The stem is richly embossed, with two lion heads connected by garlands in relief. On the upper and lower side of the stem there are two flat rings, connected to the bowl and foot.

Tableware includes glass lids, which often cannot be precisely determined. This category includes the newly discovered decorated lid (cat. no. 5; Fig. 21a-b). The leaf motifs on the surface are engraved with a diamond needle. In the central part it ends in the form of a flat knob. However, 
rekonstruirati zahvaljujući prikazima na slikama nastalima u razdoblju od početka 14. do prvih desetljeća 17. stoljeća. Jedna od njih je Posljednja večera (1476.) koju je naslikao Domenico Ghirlandaio u refektoriju samostana Ognissanti u Firenci (Petricioli 1970: 24). ${ }^{27}$ S obzirom na vratove boca koji su obrađeni u sveobuhvatnoj objavi staklene građe Irene Lazar i Hugha Willmotta, došlo se do novih spoznaja. Primjerice, vrat boce s obodom proširenim u obliku lijevka (S20b) moguće je tipološki povezati s nedavno otkrivenim vratom boce ukrašenim u tehnici filigrana (tal. vetro a fili) na kojem su vertikalne niti prozirne, a ne bijele kao što je uobičajena praksa (kat. br. 6; sl. 22a-b). Nova zapažanja odnose se i na druge uske vratove boca dekorirane u tehnici filigrana (S20c), bez ukrasa ili ukrašene jednom valovitom trakom. Oni tipološki odgovaraju novom nalazu ukrašenom dvjema apliciranim valovitim trakama (kat. br. 7; sl. 23a-b). Do sada objavljeni slični predmeti (S20c) svrstani su u skupinu ukrašenu samo jednom valovitom trakom, a ukras s dvije trake spominje Gasparetto (1976: 433).

Godine 2020. pronađena je boca kruškolikoga tijela. Oštećenje u nezinom donjem dijelu možda ukazuje na podnožje koje se, ukoliko je postojalo, nije očuvalo. Kruškoliko tijelo suženo je prema vrhu, a na vratu je aplicirana the object has not been entirely preserved. The height of the fragment measures $2 \mathrm{~cm}$, and the diameter of the opening $5 \mathrm{~cm}$. Only one specimen has been found.

In the category of containers, there are bottles, of which the necks and/or bases have often been preserved. Their shape can be reconstructed based on the paintings made from the beginning of the $14^{\text {th }}$ to the first decades of the $17^{\text {th }}$ century, such as the The Last Supper (1476), painted by Domenico Ghirlandaio in the refectory of the All-Saints Monastery in Florence (Petricioli 1970: 24). ${ }^{27}$ Given the necks of the bottles published by Irena Lazar and Hugh Willmott, new insights have been reached. For example, the neck of a bottle with a funnel-mouth rim (S20b) could be typologically linked to a recently discovered bottle neck decorated in the filigree technique (tal. vetro a fili), on which the vertical trails are transparent rather than white as in the common practice (cat. no. 6; Fig. 22a-b). The new observations also apply to other narrow bottle necks decorated in the filigree technique (S20c), without ornaments or decorated with a single wavy trail. They typologically correspond to a new find decorated with two applied wavy trails (cat. no. 7; Fig. 23a-b). Similar objects published so far (S20c) were classified in the group decorated with only one wavy trail, and the

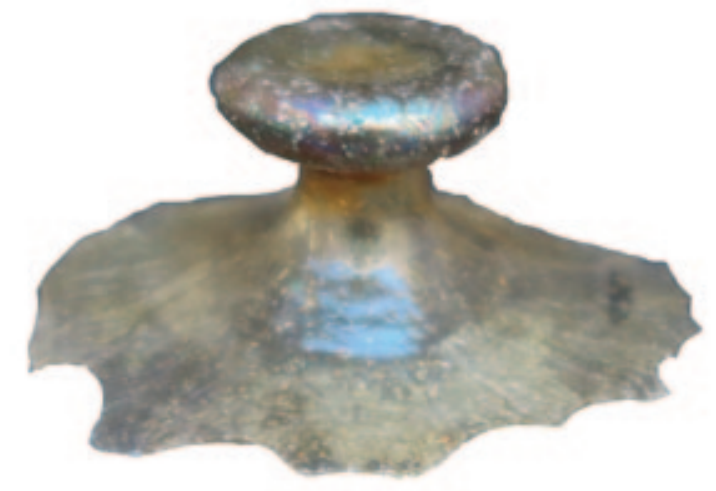

a
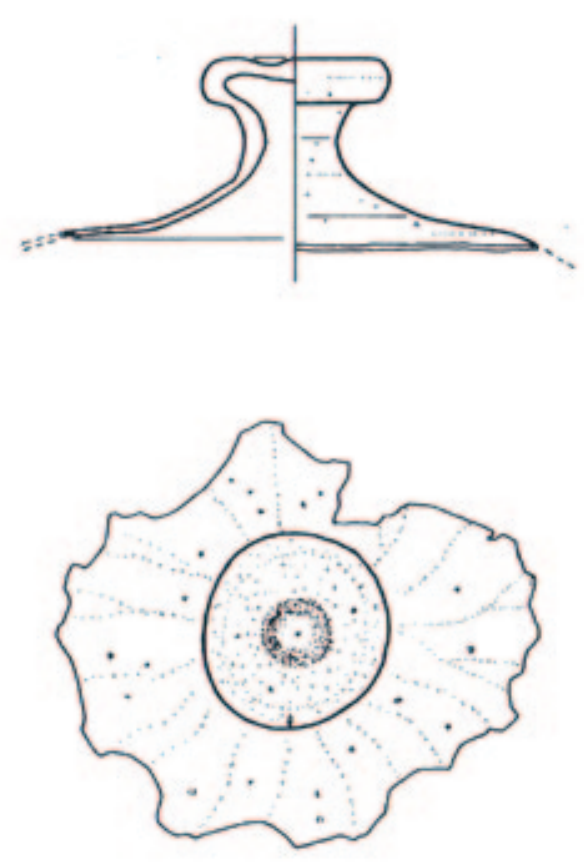

b

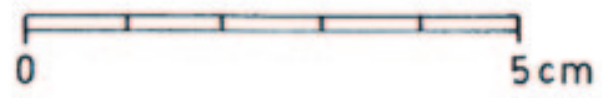

SI. 21 a-b Ukrašeni poklopac, GN.2013.209 (izvor: Arhiva projekta Brodolom kod Gnalića-ogledalo renesansnog svijeta; crtež: Z. Bakić) Fig. 21 a-b Decorated lid, GN.2013.209 (source: Archive of the Shipwreck near Gnalić project - a mirror of the Renaissance world; drawing by: Z. Bakić)

27 Webgallery ofArt, https://www.wga.hu/html_m/g/ghirland/domenico/4lastsup/ index.html.
27 Webgallery ofArt, https://www.wga.hu/html_m/g/ghirland/domenico/4lastsup/ index.html. 

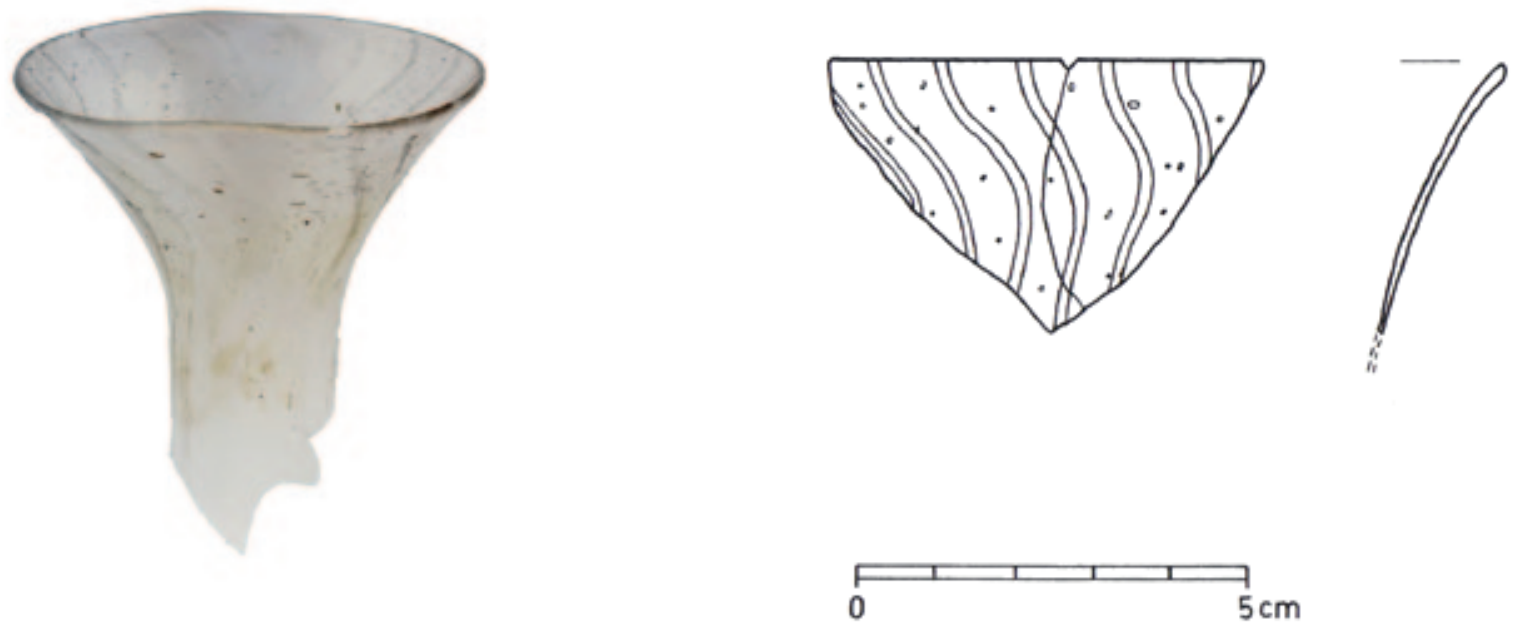

SI. 22 a-b Boca s dugim vratom i obodom proširenim u obliku lijevka, ukrašena neprozirnim bijelim nitima, GN.2015.718 (izvor: Arhiva projekta Brodolom kod Gnalića - ogledalo renesansnog svijeta; crtež: Z. Bakić)

Fig. 22 a-b Bottle with a long neck and a funnel-shaped rim, decorated with opaque white threads, GN.2015.718 (source: Archive of the Shipwreck near Gnalić project - a mirror of the Renaissance world; drawing by: Z. Bakić)
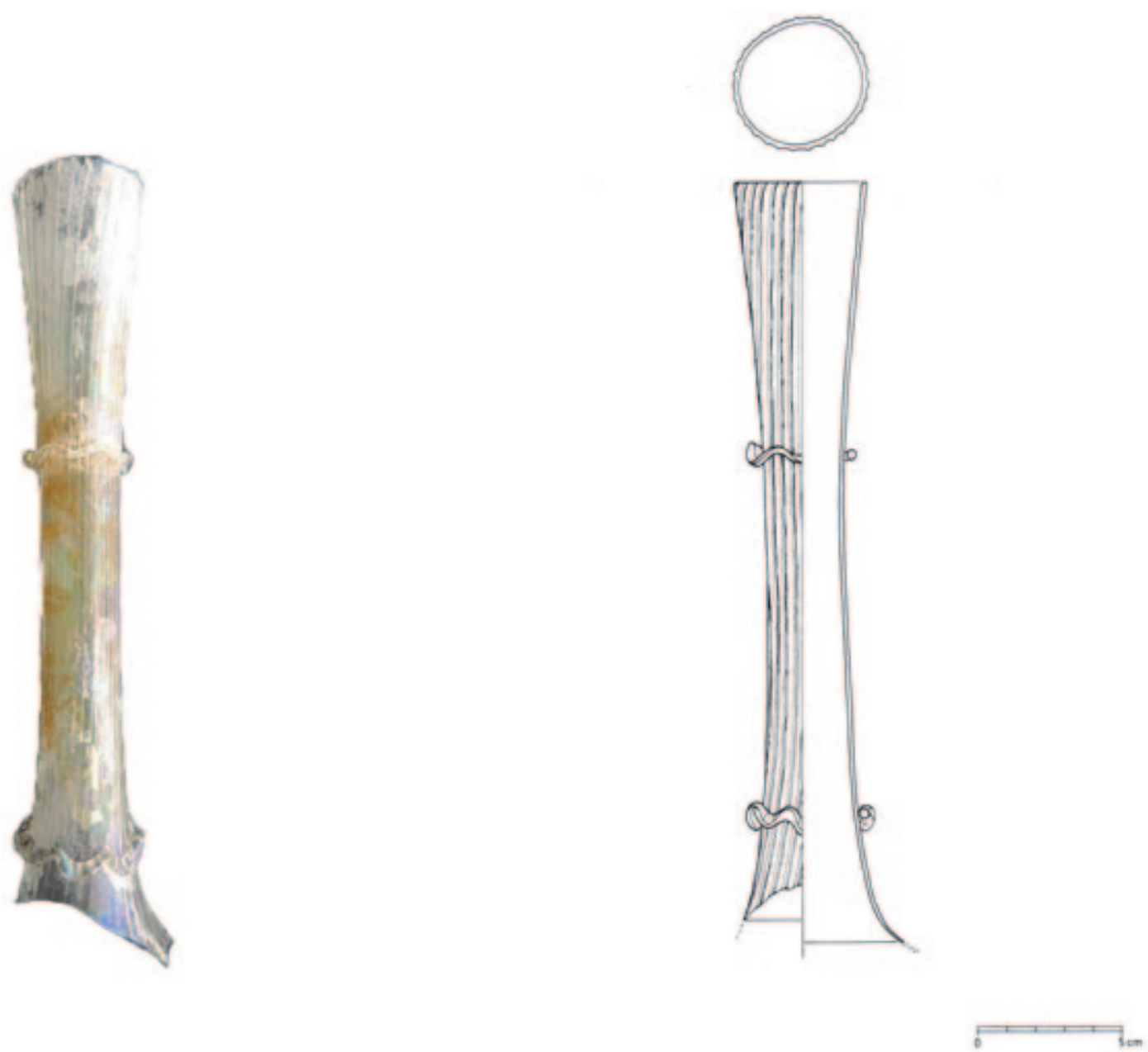

SI. 23 a-b Boca s dugim vratom, ukrašena neprozirnim bijelim nitima, GN 2013.553 (izvor: Arhiva projekta Brodolom kod Gnalića-ogledalo renesansnog svijeta; crtež: Z. Bakić)

Fig. $23 a-b$ Bottle with a long neck, decorated with opaque white threads, GN 2013.553 (source: Archive of the Shipwreck near Gnalić project - a mirror of the Renaissance world; drawing by: Z. Bakić) 


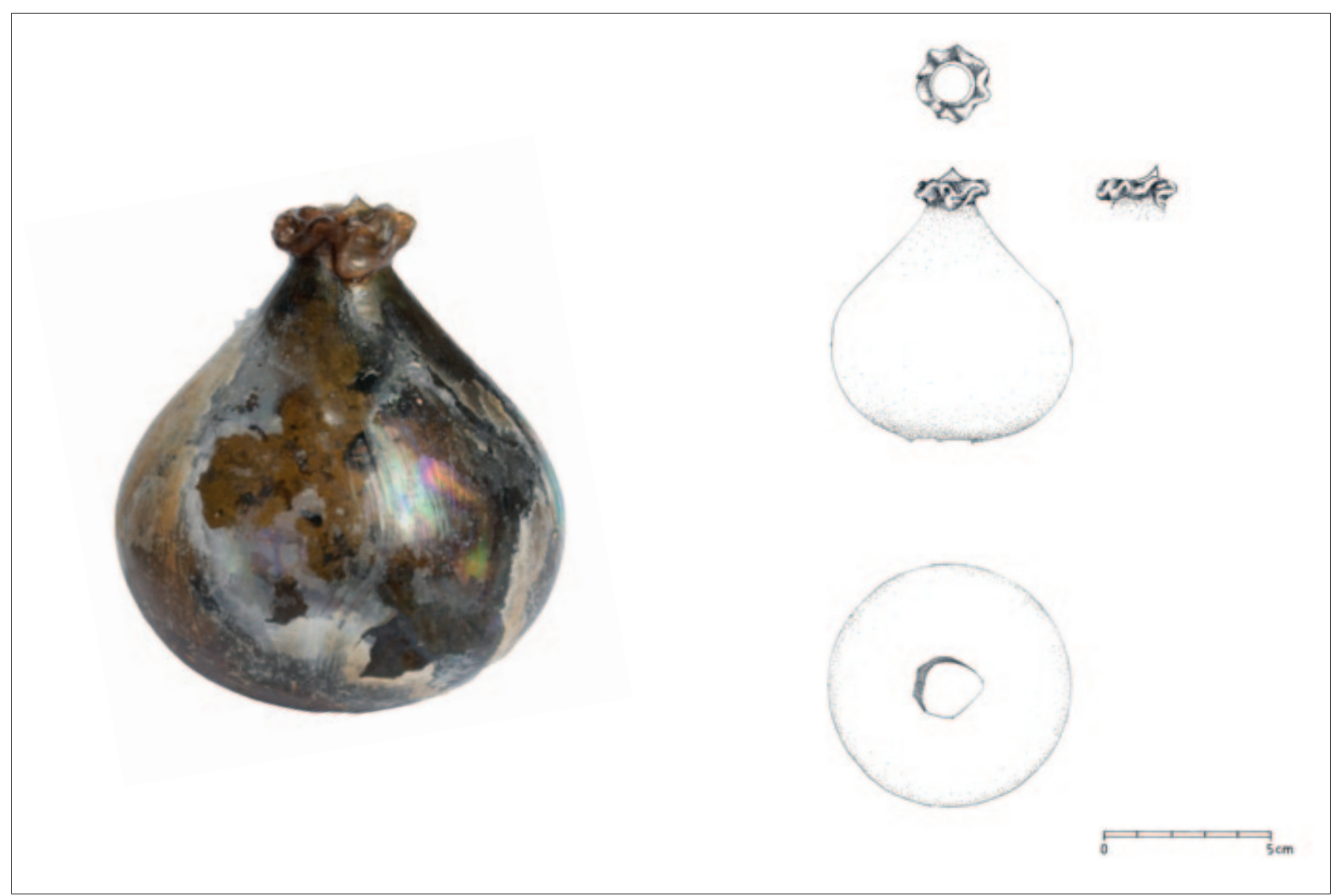

SI. 24 a-b Kruškolika boca s valovitom apliciranom trakom, GN.2020.102 (izvor: Arhiva projekta Brodolom kod Gnalića - ogledalo renesansnog svijeta; crtež: N. Cuk)

Fig. 24 a-b Pear-shaped bottle with corrugated applied tape, GN.2020.102 (source: Archive of the Shipwreck near Gnalić project - a mirror of the Renaissance world; drawing by: N. Cuk)

valovita traka (kat. br. 8; sl. 24a-b). Boca oblikom odgovara bocama za pješčani sat, ali valovita traka vjerojatno bi smetala prilikom postavljanja metalnoga obruča kojim su se dvije kruškolike boce povezivale u jednu cjelinu kako bi se proizveo spomenuti predmet, pa se ne isključuje mogućnost drugačije interpretacije.

Na nalazištu je pronađeno i obojeno staklo, a među novim nalazima ističu se dna izrađena od tamnoplavoga prozirnog stakla (kat. br. 9; sl. 25a-b) koja se mogu pripisati skupini velikih boca loptastoga tijela s dugim vratom i profiliranim rubom (S24c). Do sada su bila poznata dna promjera $6 \mathrm{~cm}$, a novootkrivena dna boca većih su dimenzija od ranije poznatih. Promjeri novih primjeraka dna iznose 7 i $8 \mathrm{~cm}$.

Tijekom novijih istraživanja pronađeno je zadebljano prstenasto dno tamnocrvene posude (kat. br. 10; sl. 26a-b), manjih dimenzija i konusno uvučeno, promjera $3,7 \mathrm{~cm}$. Pripadnost toga dna još uvijek nije definirana, kao niti pripadnost nedavno otkrivenoga dna izrađenoga od obojenog stakla i u tehnici kalcedonskoga stakla. Podloga za njegovu izradu bilo je, čini se, plavo obojeno staklo s umetnutim komadićima stakla crvene boje koji su uzrokovali nejednak crveni preljev po površini predmeta (kat. br. 11; sl. 27a-b). decoration with two trails is mentioned by Gasparetto (1976: 433).

In 2020, a pear-shaped bottle was found. Damage at its lower part indicates that it may have had a foot which, if it existed, has not been preserved. The pear-shaped body is tapered towards the top, and a wavy trail is applied to the neck (cat. no. 8; Fig. 24a-b). The shape of the object corresponds to an hourglass bottle, but the wavy trail would probably be interfering when placing a metal hoop with which two pear-shaped bottles would have been connected in order to produce an hourglass. Therefore, a different interpretation is warranted.

As previously stated, coloured glass was also found at the site. Among the new finds are bottoms made of dark blue transparent glass (cat. no. 9; Fig. 25a-b), which can be attributed to the group of large bottles of a spherical body, long neck and stepped rim (S24c). So far, bases of diameter of $6 \mathrm{~cm}$ have been known. The newly discovered bases are larger than those previously known, measuring 7 and $8 \mathrm{~cm}$.

During recent excavations, a thickened annular bottom of a dark red vessel (cat. no. 10; Fig. 26a-b), smaller in size and conically indented, $3.7 \mathrm{~cm}$ in diameter, was found. The affiliation of this bottom to a specific vessel type has not 


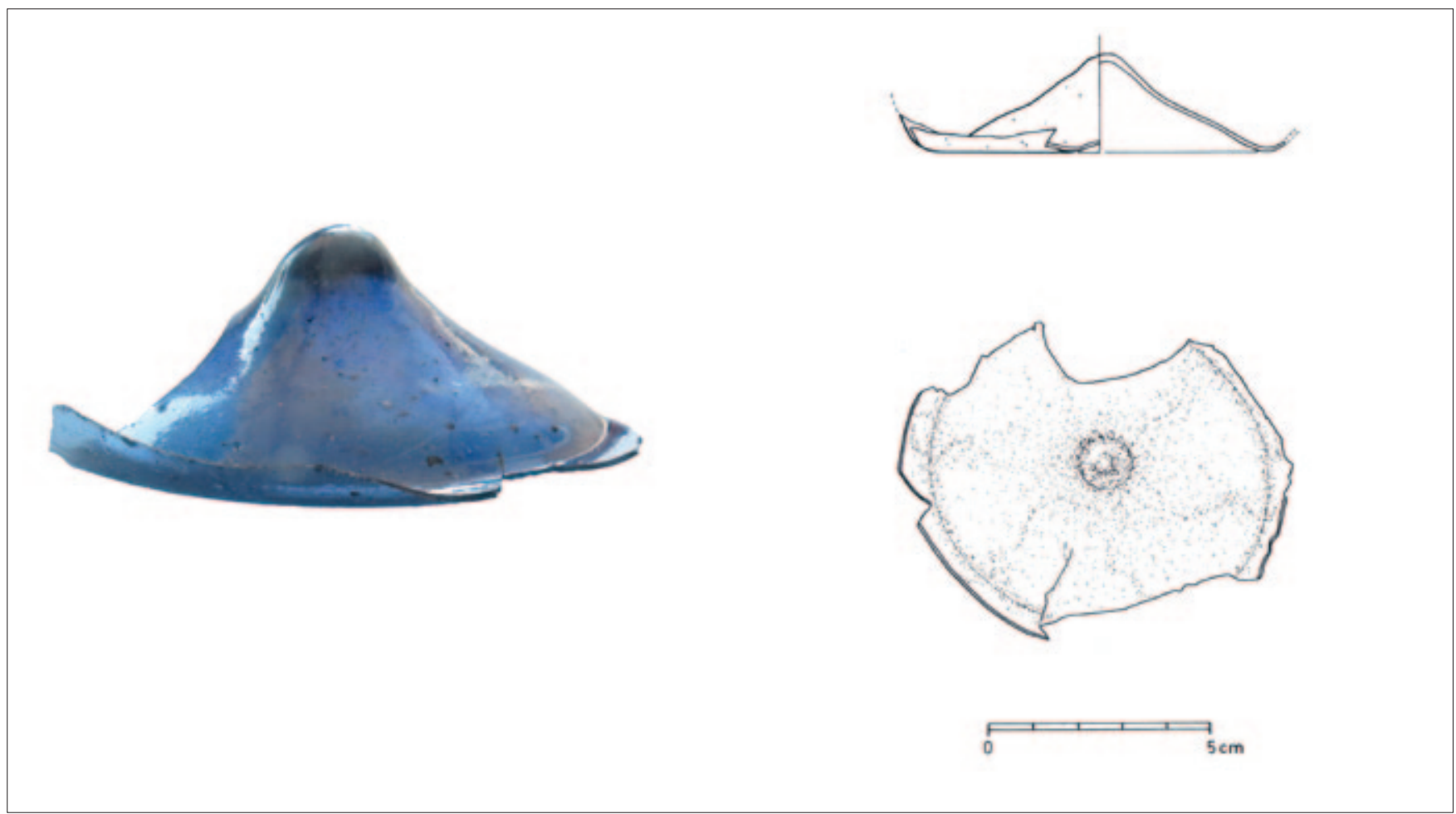

SI. 25 a-b Dno velike boce kuglastoga tijela, s dugim vratom i profiliranim rubom (?), GN.2016.1240 (izvor: Arhiva projekta Brodolom kod Gnalića - ogledalo renesansnog svijeta; crtež: Z. Bakić)

Fig. 25 a-b The bottom of a large bottle with a spherical body, with a long neck and a profiled edge (?), GN.2016.1240 (source: Archive of the Shipwreck near Gnalić project - a mirror of the Renaissance world; drawing by: Z. Bakić)

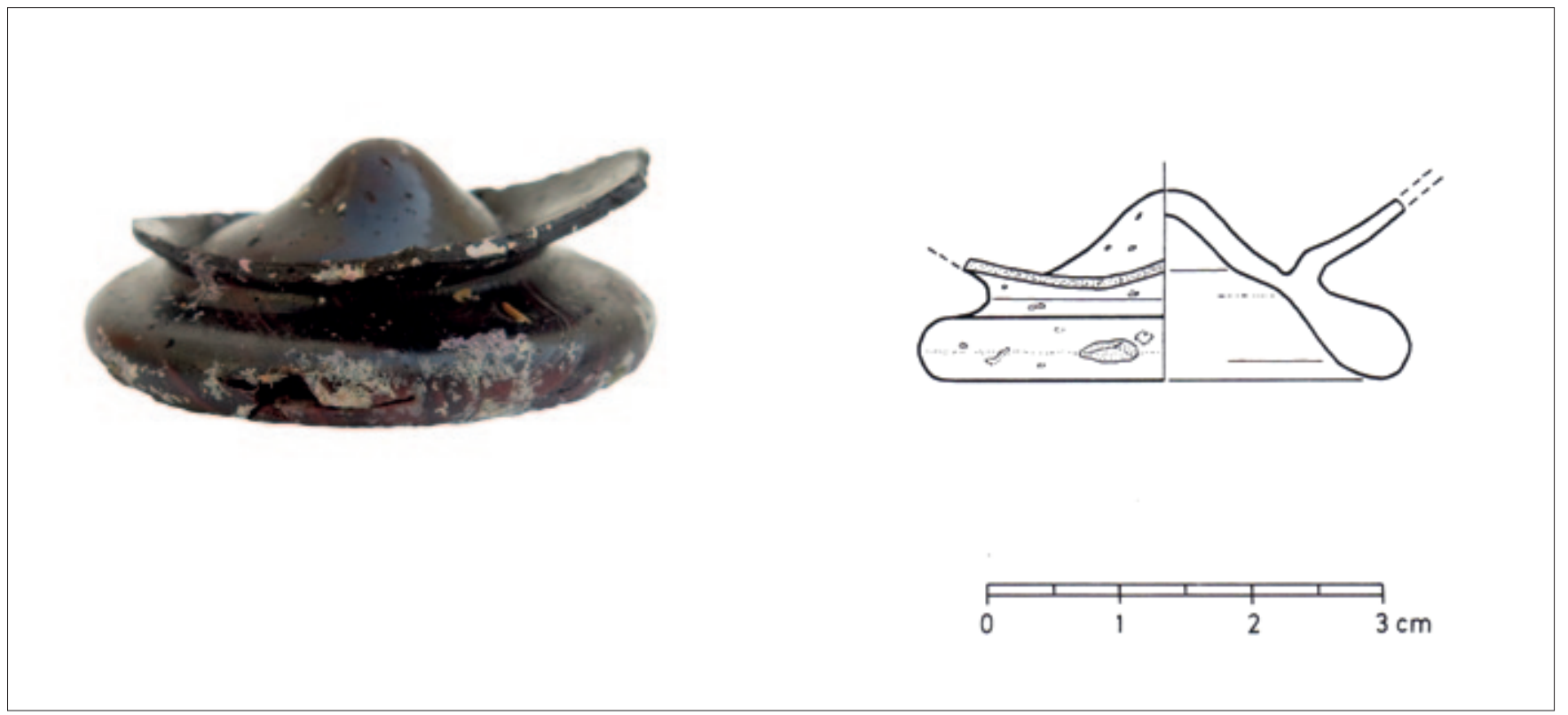

SI. 26 a-b Dno posude tamnocrvene boje, GN.2015.709 (izvor: Arhiva projekta Brodolom kod Gnalića - ogledalo renesansnog svijeta; crtež: Z. Bakić)

Fig. $26 a-b$ The bottom of the vessel is dark red, GN.2015.709 (source: Archive of the Shipwreck near Gnalić project - a mirror of the Renaissance world; drawing by: Z. Bakić)

Među neidentificirane predmete ubraja se i stakleni predmet plave boje, možda dekorativni element ili dno neke posude. Okrugla pločica odlikuje se reljefno izvedenim točkastim ukrasom koji se sastoji od šest točkica raspoređenih u krug oko jedne središnje točkice (kat. br. 12; sl. 28a-b). $U$ istu kategoriju neidentificiranih predmeta ide yet been defined, nor has it been done for the recently discovered bottom, made of coloured glass and in the chalcedony glass technique. It seems that the basis for its production was the blue glass with inserted pieces of red glass, which caused an uneven red overflow on the surface of the object (cat. no. 11; Fig. 27a-b). 

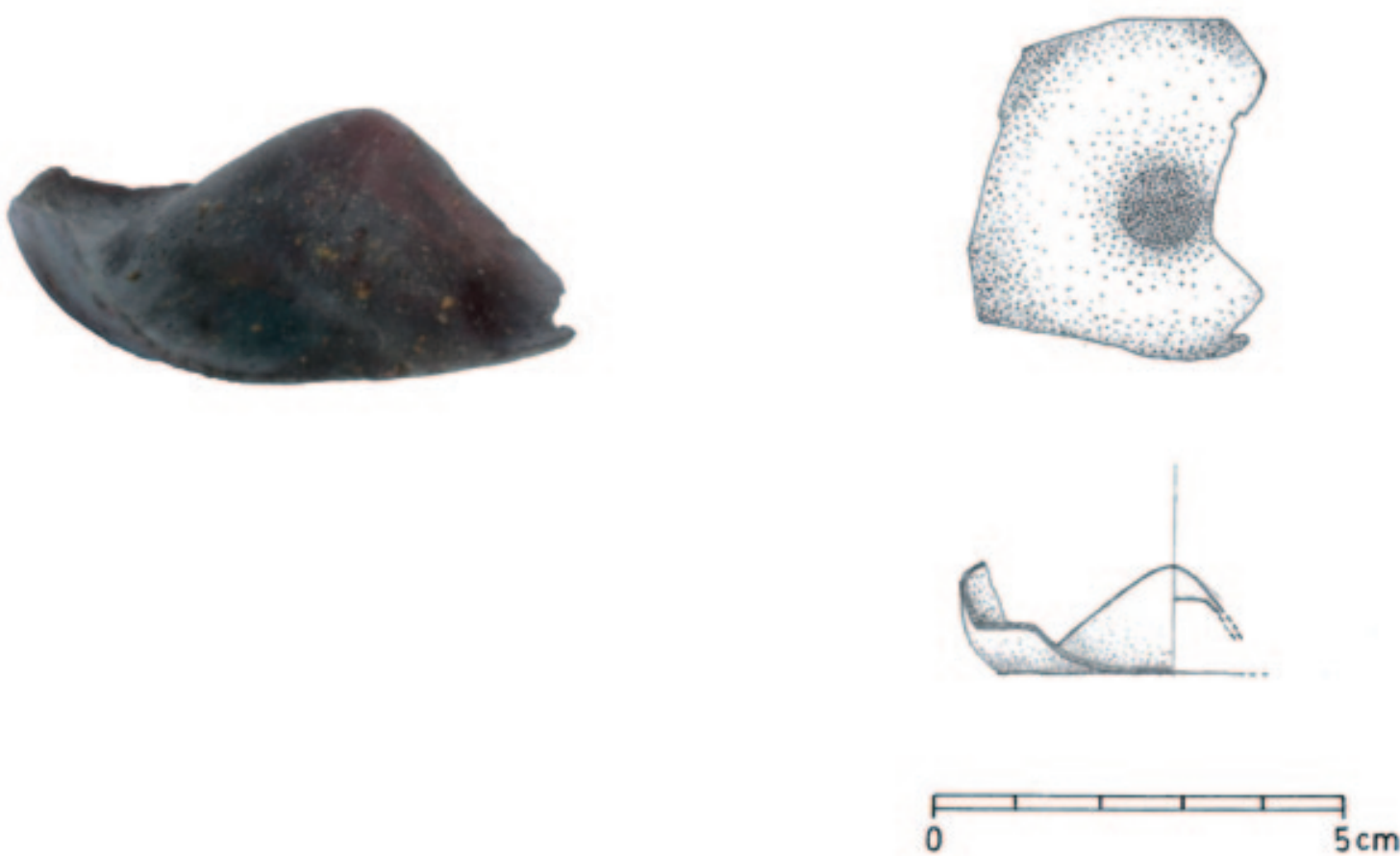

Sl. 27 a-b Jednostavno uvučeno dno od obojenoga stakla, GN.2020.58 (izvor: Arhiva projekta Brodolom kod Gnalića - ogledalo renesansnog svijeta; crtež: N. Ćuk)

Fig. 27 a-b Simply indented bottom made of coloured glass, GN.2020.58 (source: Archive of the Shipwreck near Gnalić project - a mirror of the Renaissance world; drawing by: N. Cuk)
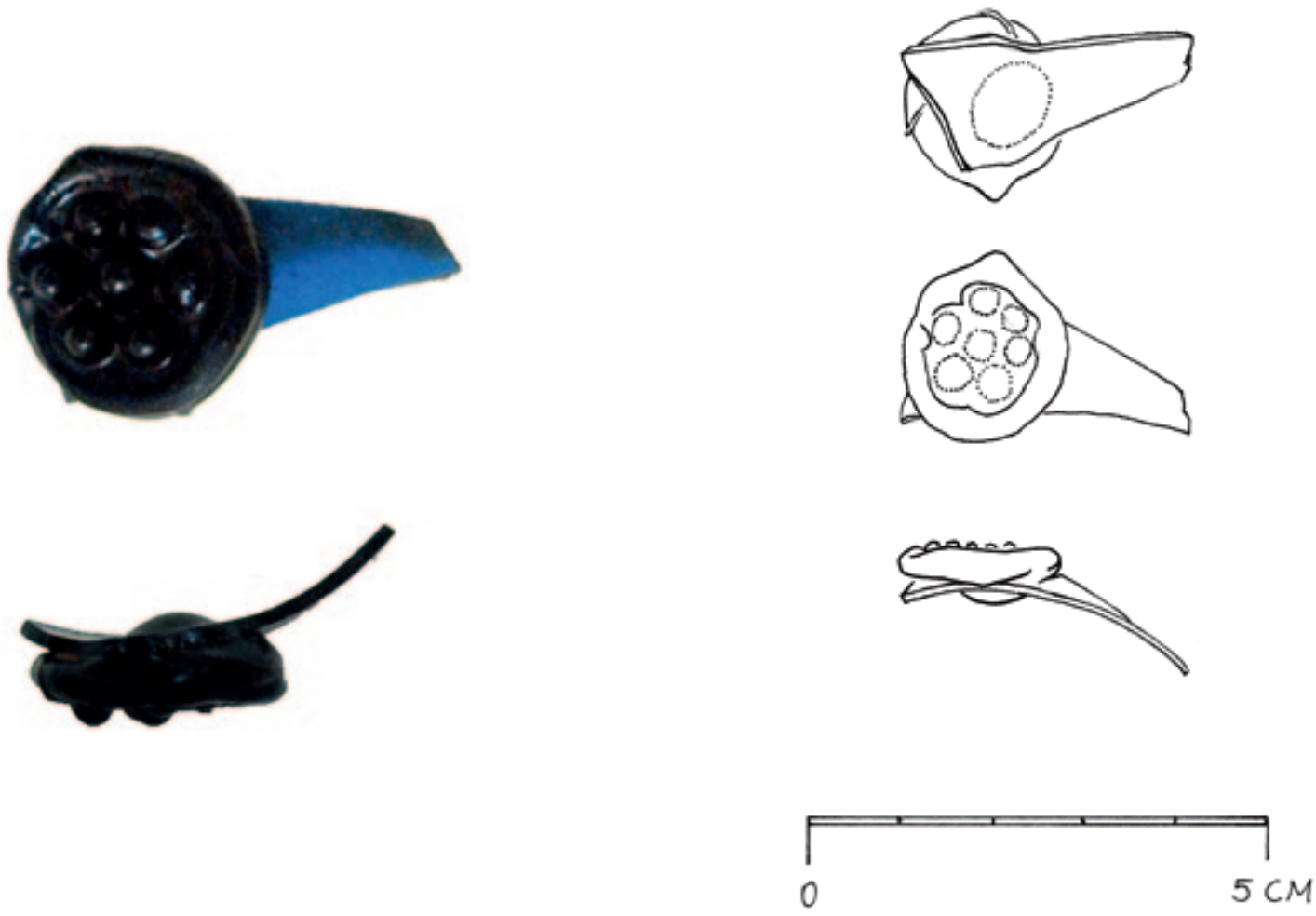

SI. 28 a-b Dekorativni element (?) neidentificiranoga predmeta plave boje, GN.2013.618 (izvor: Arhiva projekta Brodolom kod Gnalića - ogledalo renesansnog svijeta; crtež: N. Ćuk)

Fig. 28 a-b Decorative element (?) of an unidentified blue object, GN.2013.618 (source: Archive of the Shipwreck near Gnalić project - a mirror of the Renaissance world; drawing by: N. Cuk) 


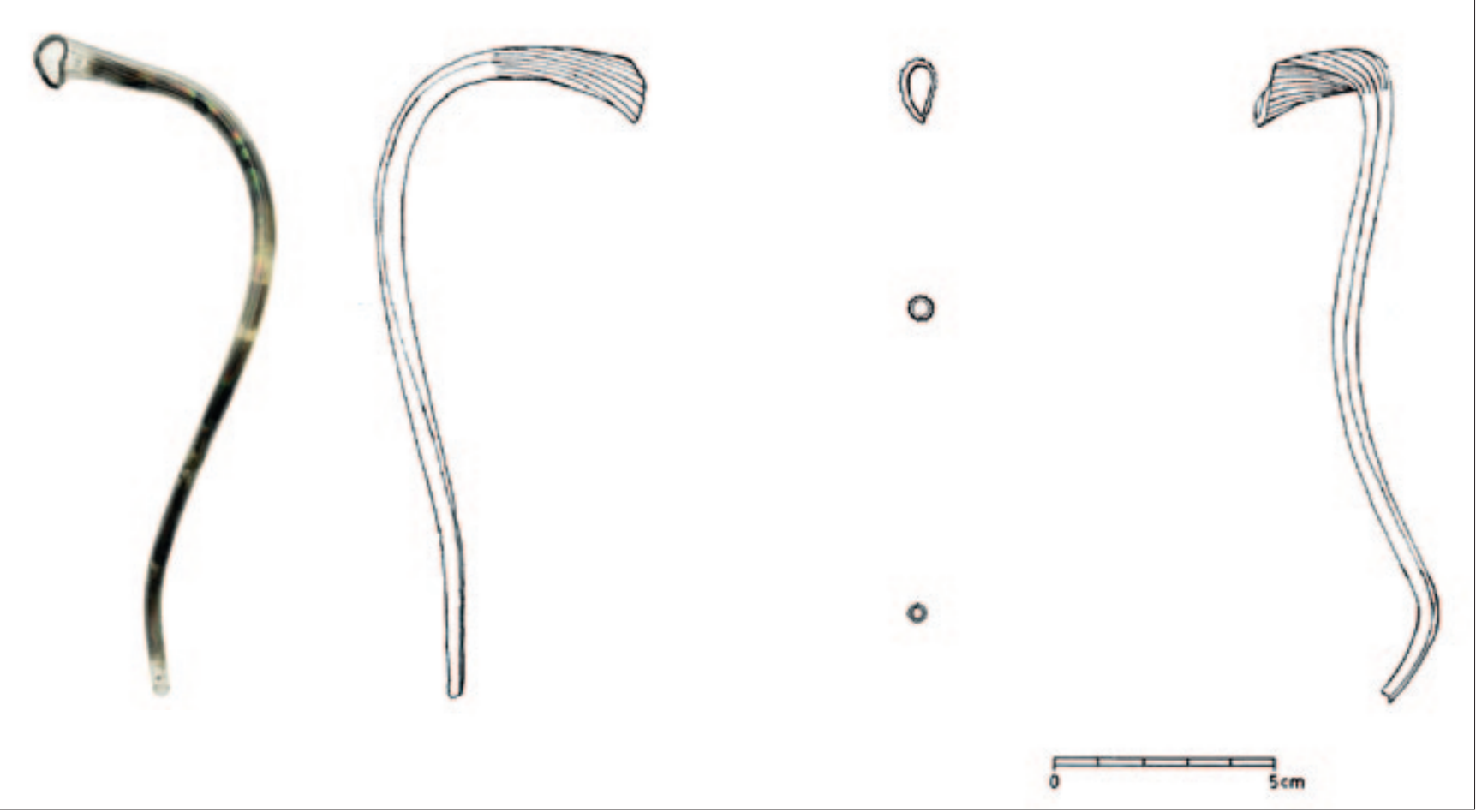

SI. 29 a-b Ručka izrađena optičkim puhanjem, GN.2020.56 (izvor: Arhiva projekta Brodolom kod Gnalića-ogledalo renesansnog svijeta; crtež: N. Ćuk)

Fig. 29 a-b Handle made by optical blowing, GN.2020.56 (source: Archive of the Shipwreck near Gnalić project - a mirror of the Renaissance world; drawing by: N. Cuk)

i pronađena staklena ručka izrađena optičkim puhanjem u kalupu, s rebrastom dekoracijom i dodatnim uvijanjem (kat. br. 13; sl. 29a-b). Točna pripadnost ručke za sada još nije određena.

U skupini ravnoga stakla zamijećeni su jedno dovršeno okruglo staklo za ogledalo koje se od ostalih razlikuje dimenzijama te novi ukrasni motivi na prozorskim staklima. Okrugla stakla za ogledala u dosadašnjoj literaturi navode se u dvije veličine, promjera 8,6 i $10,6 \mathrm{~cm}$. Malo okruglo staklo za ogledalo, promjera $3 \mathrm{~cm}$, odlikuje se poliranom površinom i rubovima rezanima do željenoga oblika (kat. br. 14; sl. 30a-b). Kao i ostali primjerci stakala za ogledala, izrađen je lijevanjem staklene mase na glatku kamenu površinu. S obzirom na izrazito male dimenzije možda je riječ o robi koja se u dokumentima navodi u skupini ogledala 'da libretto' ('na knjižicu') tj. malih prijeklopnih ogledala (Gasparetto 1976: 445).

Ukrašena okrugla prozorska stakla (S24b) objavljena su u monografiji Irene Lazar i Hugha Willmotta i u katalogu izložbe održane u Hrvatskome povijesnom muzeju 2013. i 2014. godine (Lazar, Willmott 2006a: 72; Filep et al. 2013: 156). U ranijim istraživanjima pronađeno je sveukupno 14 primjeraka, od kojih niti jedan nije očuvan u punome promjeru, pa nije moguće utvrditi koliko je različitih dimenzija tih stakala bilo prisutno u brodskome teretu. ${ }^{28} \mathrm{U}$ novijim istraživanjima pronađeno je jedno staklo koje se

28 U katalogu Filep et al. (2013: 156) spominju se stakla u dvije očuvane veličine od 11 i $21 \mathrm{~cm}$.
Unidentified pieces include a blue glass object, perhaps a decorative element, or the bottom of a vessel. The round tile is characterized by an embossed dot decoration, consisting of six dots arranged in a circle around the central one (cat. no. 12; Fig. 28a-b). The same category of unidentified objects includes a glass handle made by optical blowing in a mould, with wavy decoration and additional twisting (cat. no. 13; Fig. 29a-b). The type of the vessel to which the handle belongs has not yet been determined.

In the group of flat glass, one entirely preserved round mirror glass was noticed, which differs in size from the others. There are also some new decorative motifs on the window panes. In the previously published literature, round glasses for mirrors were listed in two sizes, 8.6 and $10.6 \mathrm{~cm}$ in diameter. A small round mirror glass, $3 \mathrm{~cm}$ in diameter, has a polished surface and edges cut to the desired shape (cat. no. 14; Fig. 30a-b). Like other mirror glasses, it is made by casting glass paste on a smooth stone surface. Given its extremely small dimensions, it may be a commodity that is mentioned in documents in the group of mirrors ' $d a$ libretto' ('on the booklet'), i.e. small portable folding mirrors (Gasparetto 1976: 445).

Decorated round window panes (S24b) were published in the monograph of Irena Lazar and Hugh Willmott, and in the catalogue of the exhibition held at the Croatian History Museum in 2013-2014 (Lazar, Willmott 2006a: 72; Filep et al. 2013: 156). In previous research, a total of 14 specimens were found, none of which have been preserved in full diameter. Therefore, it is not possible to determine how many different dimensions of these window panes were 
očuvalo u punom promjeru od $17,8 \mathrm{~cm}$, a rozeta sa osam latica, kojom je ukrašeno, poznata je iz ranijih istraživanja (kat. br. 15; sl. 31-33). Kako se do sada nitko nije pozabavio sustavnom obradom rozetnih ukrasa izrađenih tehnikom optičkoga puhanja, o njima se može suditi na osnovi objavljenih fotografija i crteža. U publikaciji Irene Lazar i present in the ship's cargo. ${ }^{28}$ In recent research, one window pane has been preserved in a full diameter of $17.8 \mathrm{~cm}$, decorated with a rosette composed of eight petals, already known from previous research (cat. no. 15; Figs. 31-33) As so far no one systematised the rosette ornaments made by technique of optical blowing, they can be judged just on

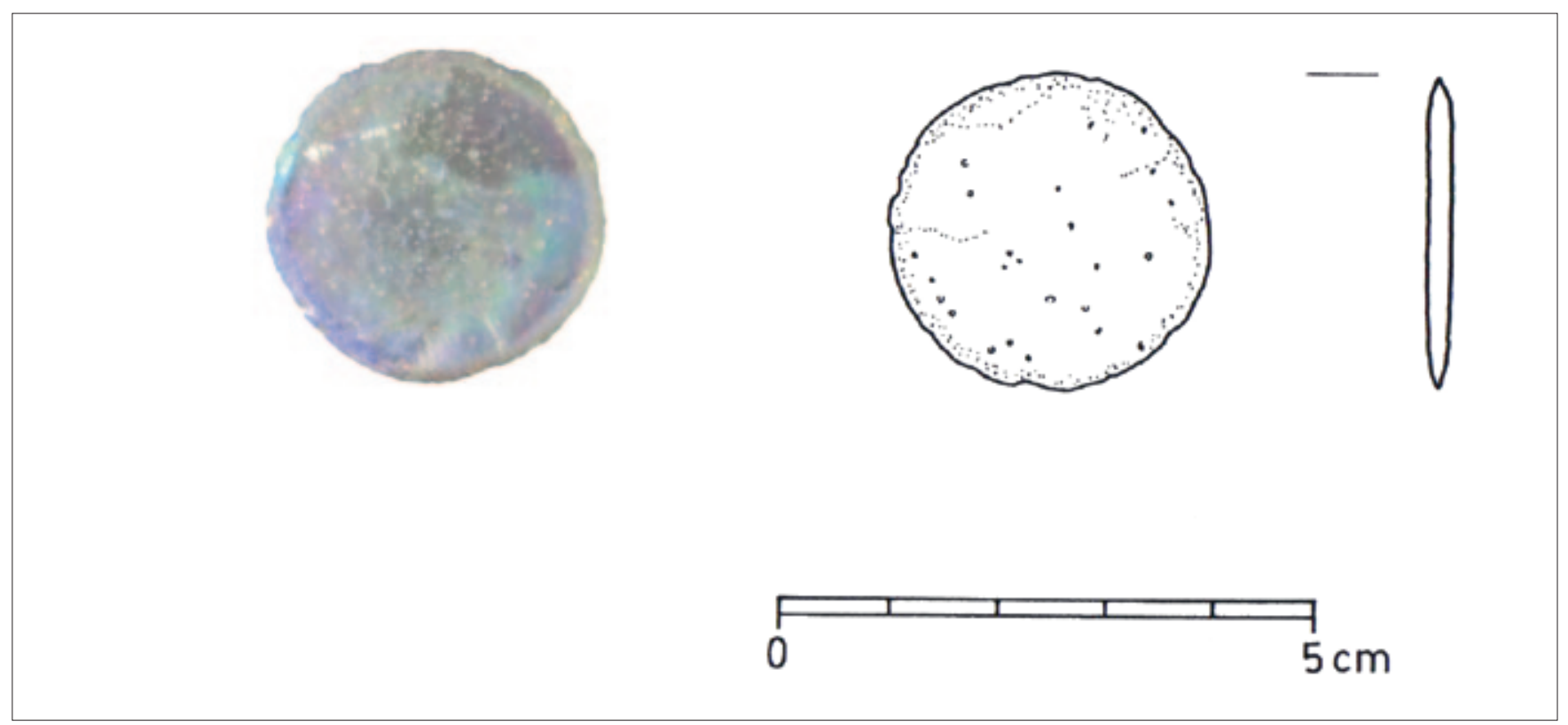

SI. 30 a-b Malo okruglo dovršeno ogledalo, GN.2013.743 (izvor: Arhiva projekta Brodolom kod Gnalića - ogledalo renesansnog svijeta; crtež: Z. Bakić)

Fig. 30 a-b Small round finished mirror, GN.2013.743 (source: Archive of the Shipwreck near Gnalić project - a mirror of the Renaissance world; drawing by: Z. Bakić)

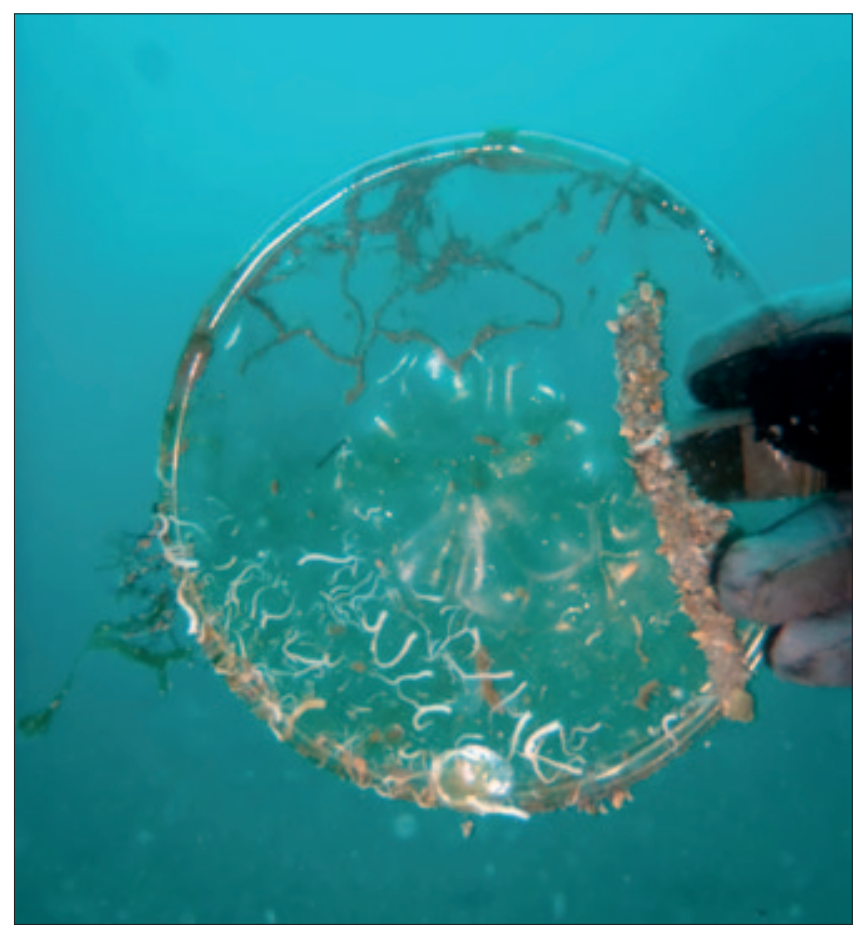

SI. 31 Cjelovito očuvano prozorsko staklo, ukrašeno rozetom s osam latica, pronađeno u površinskome sloju nalazišta (snimio: M. Lete)

Fig. 3 Completely preserved window glass, decorated with a rosette with eight petals, found in the surface layer of the site (photo by: M. Lete)

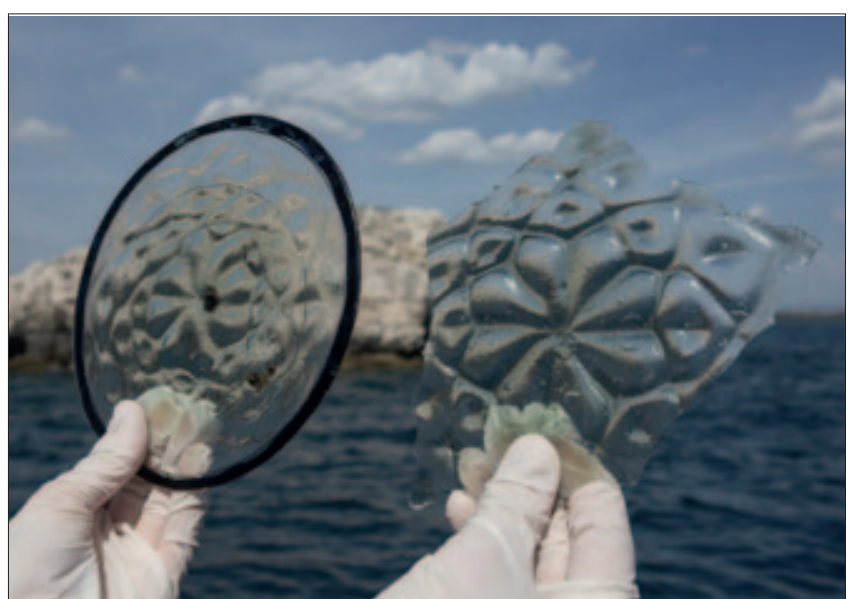

SI. 32 Cjelovito očuvano prozorsko staklo i ulomak prozorskoga stakla, ukrašeni rozetama s osam latica (snimio: S. Govorčin)

Fig. 32 Completely preserved window glass and a fragment of window glass, decorated with rosettes with eight petals (photo by: S. Govorčin)

the basis of published photographs and drawings. In the publication of Irena Lazar and Hugh Willmott, two variants of decoration with a central rosette composed of eight petals (larger specimen) and fifteen petals (smaller specimen) were

28 The catalogue Filep et al. (2013: 156) mentions glasses in two preserved sizes of 11 and $21 \mathrm{~cm}$. 
Hugha Willmotta objavljene su dvije varijante ukrasa sa središnjom rozetom od osam latica (veći primjerak) i petnaest latica (manji primjerak), a u spomenutome katalogu izložbe varijanta s jedanaest latica (veći primjerak) i sedam latica (manji primjerak) (Lazar, Willmott 2006a: 138; Filep et al. 2013: 156, sl. 132). U svim slučajevima prostor oko središnje rozete ispunjen je saćastim ukrasom.

Nova istraživanja iznijela su na svjetlost dana prozorska stakla ukrašena središnjim rozetama sa sedam (kat. br. 16; sl. 34a-b), drugom varijantom s osam (kat. br. 17; sl. 35), jedanaest (kat. br. 18; sl. 36a-b) i petnaest latica (kat. br. 19; sl. 37a-b) izvedenih na različite načine oko kojih se nastavlja saćasti ukras. Samo u jednome slučaju ukras je izveden bez središnje rozete (sl. 38). Ukrašenim prozorskim staklima potrebno je u budućnosti posvetiti više pozornosti te sustavno obraditi sve varijante ukrasa.

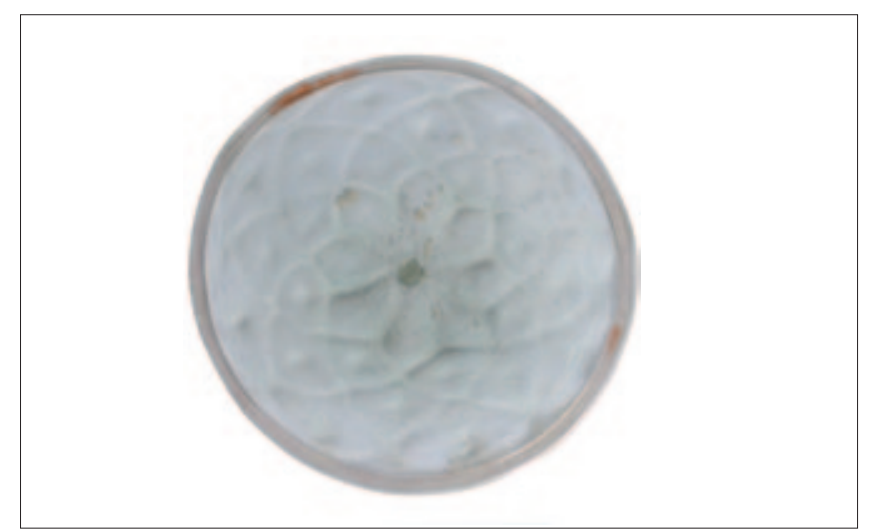

SI. 33 Cjelovito očuvano prozorsko staklo, ukrašeno rozetom s osam latica, GN.2015.1451 (izvor: Arhiva projekta Brodolom kod Gnalića - ogledalo renesansnog svijeta)

Fig. 33 Completely preserved window glass, decorated with a rosette with eight petals, GN.2015.1451 (source: Archive of the Shipwreck near Gnalić project - a mirror of the Renaissance world)

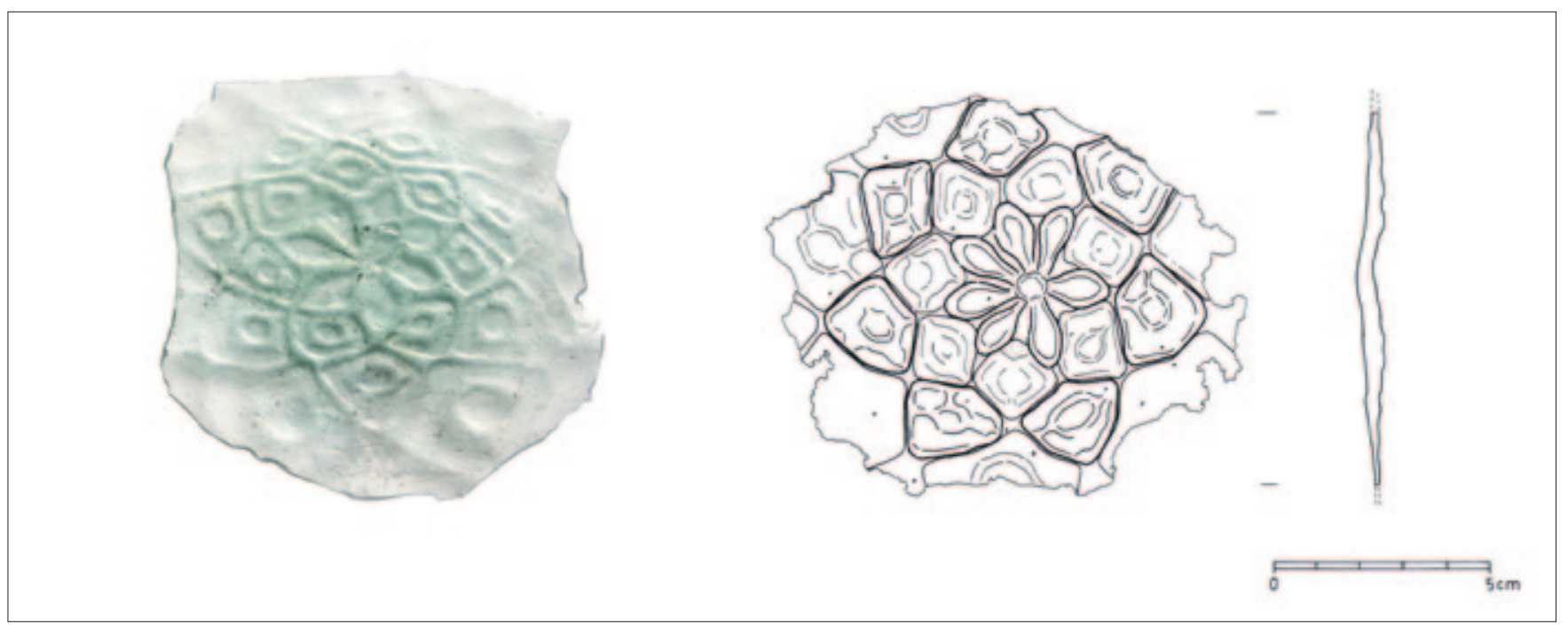

SI. 34 a-b Ulomci prozorskih stakala ukrašeni rozetama sa sedam latica, GN. 2016.599 (snimio: I. Asić; crtež: Z. Bakić)

Fig. 34 a-b Fragments of window panes decorated with rosettes with seven petals, GN. 2016.599 (photo by: I. Asić; drawing by: Z. Bakić)

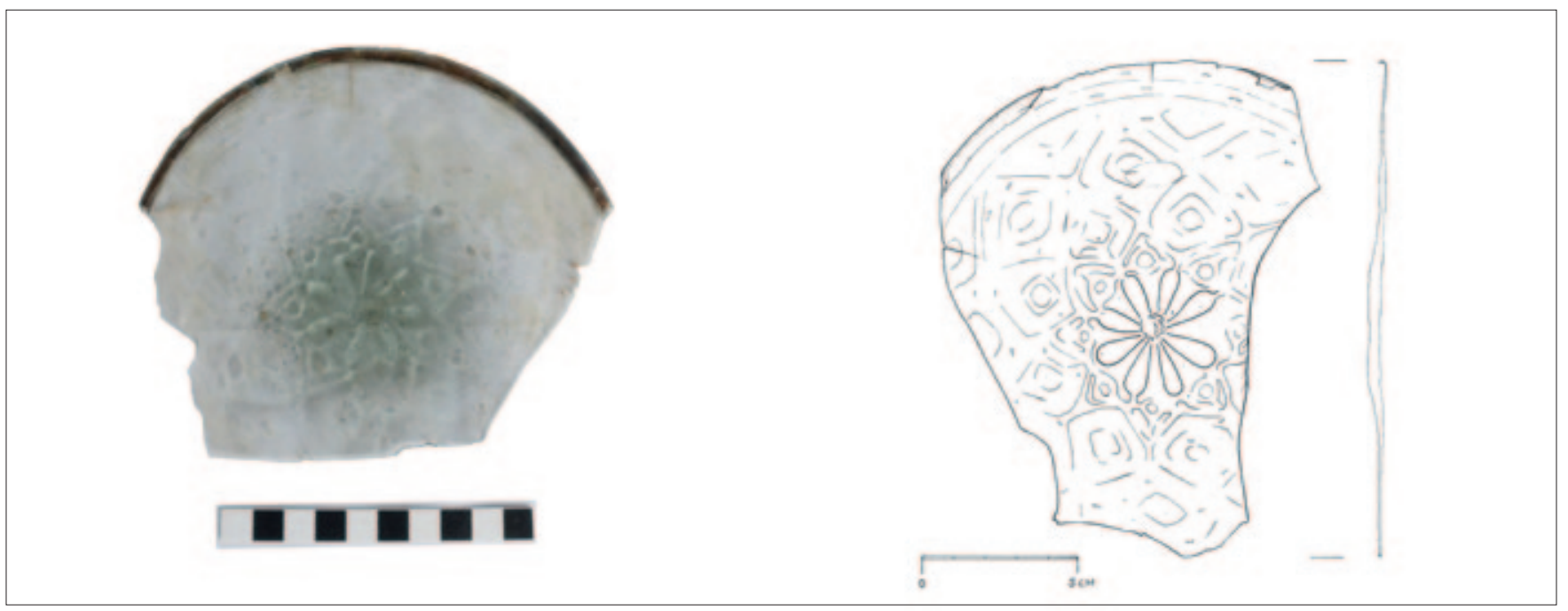

SI. 35 a-b Ulomak prozorskoga stakla ukrašen rozetom s osam latica, druga varijanta, GN.2015.947 (izvor: Arhiva projekta Brodolom kod Gnalića - ogledalo renesansnog svijeta; crtež: N. Ćuk)

Fig. 35 a-b Fragment of window pane decorated with a rosette with eight petals, second variant, GN.2015.947 (source: Archive of the Shipwreck near Gnalić project - a mirror of the Renaissance world; drawing by: Z. Bakić) 


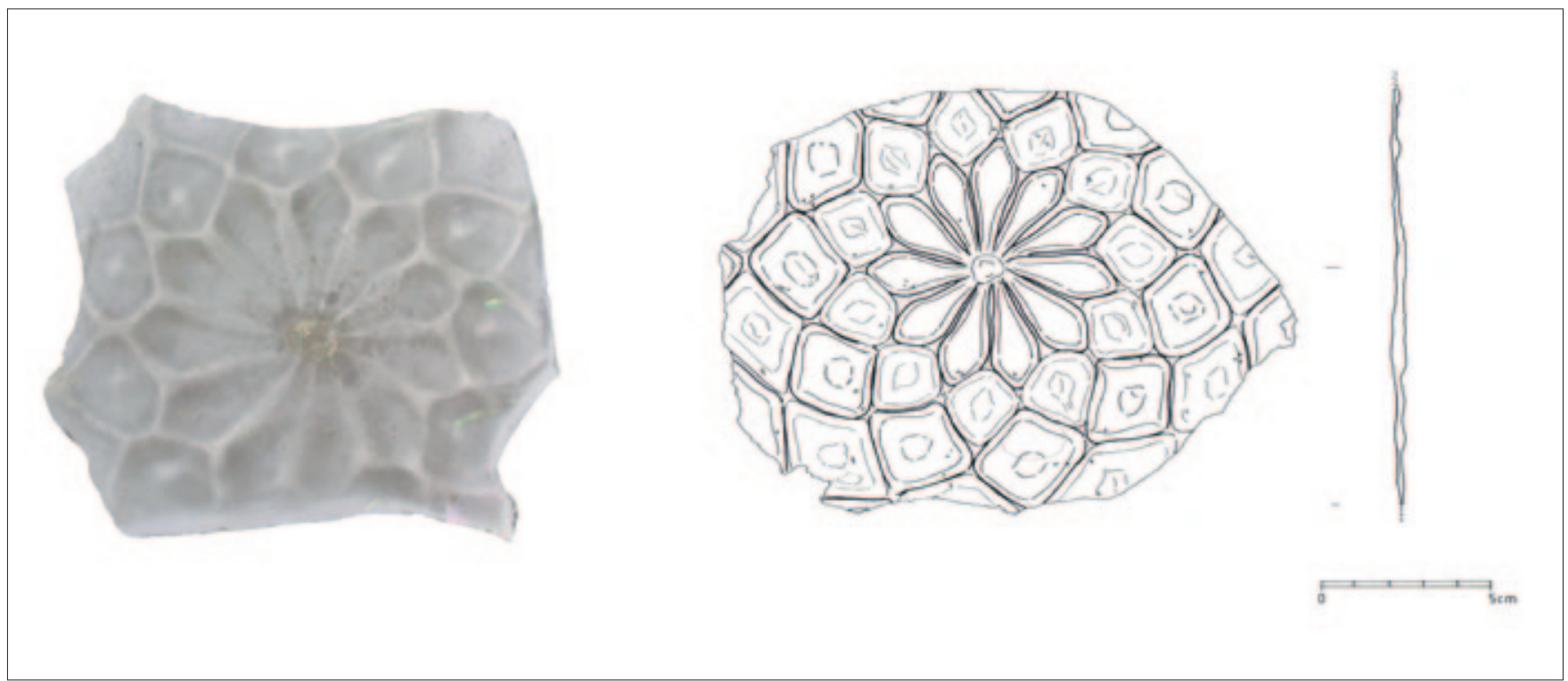

SI. 36 a-b Ulomci prozorskih stakala ukrašeni rozetama s jedanaest latica, GN. 2015.1736 (izvor: Arhiva projekta Brodolom kod Gnalića - ogledalo renesansnog svijeta; crtež: Z. Bakić)

Fig. 36 a-b Fragments of window panes decorated with rosettes with eleven petals, GN. 2015.1736 (source: Archive of the Shipwreck near Gnalić project - a mirror of the Renaissance world; drawing: Z. Bakić)

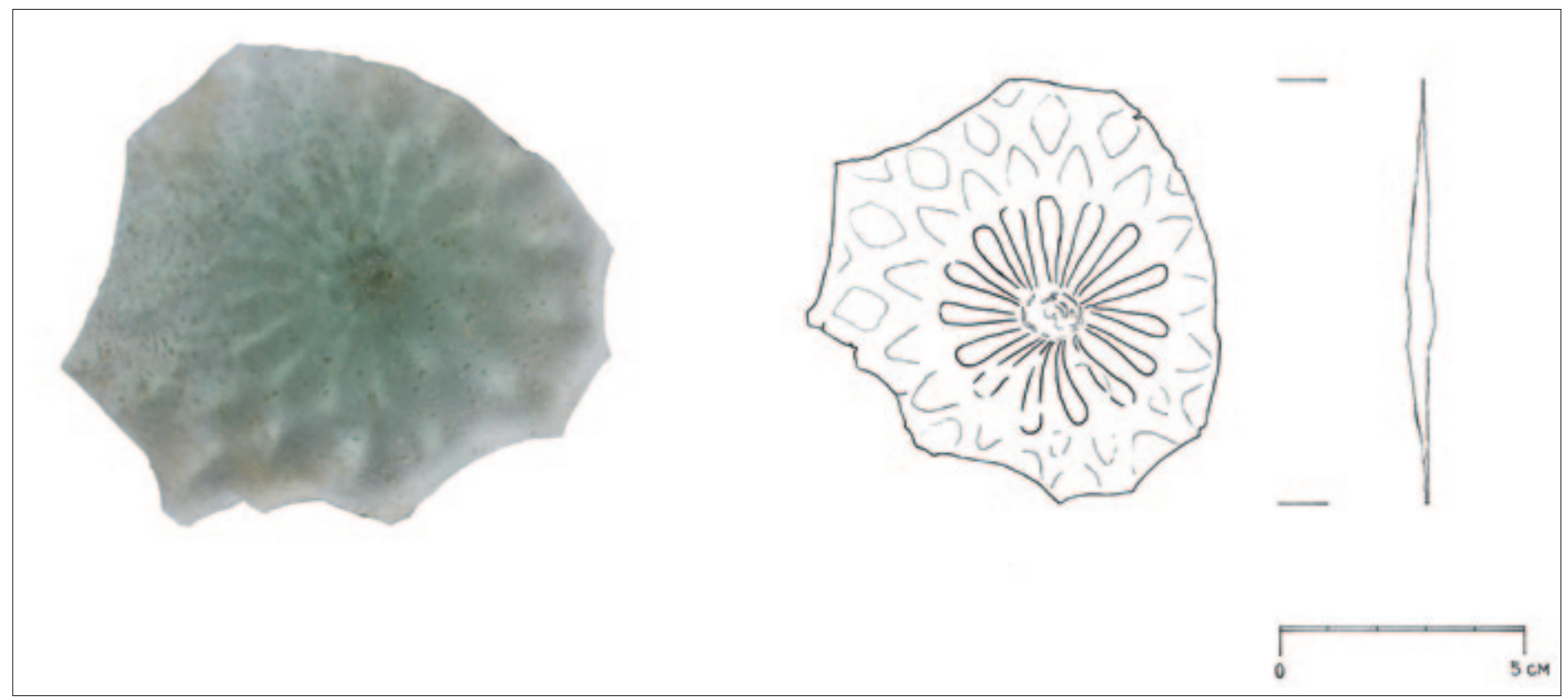

SI. 37 a-b Ukrašena prozorska stakla s petnaest latica, GN.2013.496 (izvor: Arhiva projekta Brodolom kod Gnalića - ogledalo renesansnog svijeta; crtež: N. Ćuk)

Fig. 37 a-b Decorated window panes with fifteen petals, GN.2013.496 (source: Archive of the Shipwreck near Gnalić project - a mirror of the Renaissance world; drawing by: Z. Bakić)

Zahvaljujući arhivskim istraživanjima ${ }^{29}$ koja su, tragom Gasparettovih otkrića, dovela do konačne potvrde kako je riječ o brodu koji je u trenutku potonuća (sl. 39) pripadao obitelji da Gagliano i u pisanim izvorima nazivao se Gagliana grossa, do danas se ušlo u trag mnogim dokumentima koji govore o njegovoj izgradnji, dinamičnoj životnoj priči te o robi i ljudima koji su se na njemu zatekli tijekom posljednjega putovanja. ${ }^{30}$ Šifrirana poruka kojom je bailo ${ }^{31}$ Giovanni Francesco

29 Istraživanja u Državnome arhivu u Veneciji proveli su Mauro Bondioli i Mariangela Nicolardi.

30 Priča je u detalje ispričana u knjizi Radić Rossi, Nicolardi 2019: 103-157.

31 Mletački veleposlanik u Carigradu. published, and in the mentioned catalogue of the exhibition there is a variant with a rosette composed of eleven petals (larger specimen) and seven petals (smaller specimen), (Lazar, Willmott 2006a: 138; Filep et al. 2013: 156, Fig. 132). In all cases, the space around the central rosette is filled with honeycomb decoration.

New research has brought to light window panes decorated with central rosettes composed of seven petals (cat. no. 16; Fig. 34a-b), and another variant composed of eight (cat. no. 17; Fig. 35), eleven (cat. no. 18; Fig. 36a-b) and fifteen petals (cat. no. 19; Fig. 37a-b), elaborated in different 


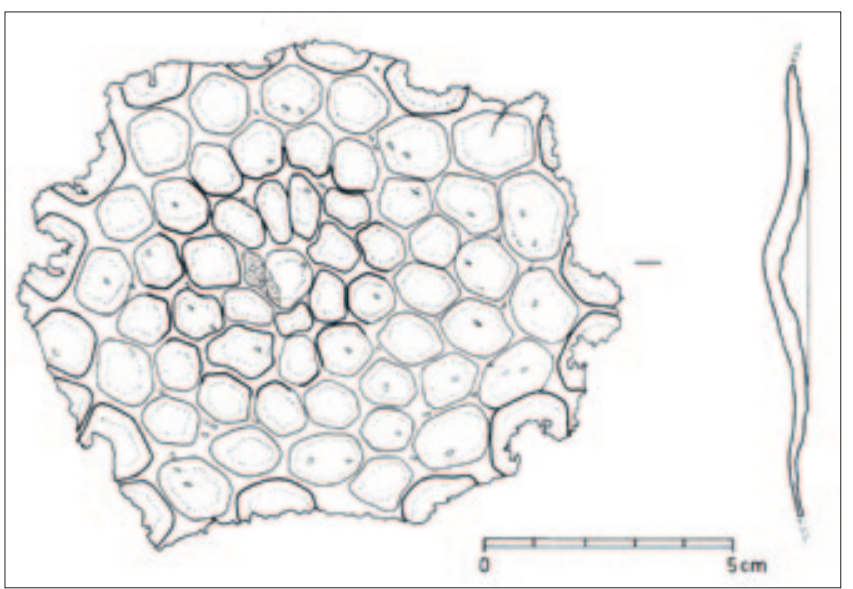

SI. 38 Ulomak prozorskoga stakla s ukrasom izvedenim bez središnje rozete, GN.2015.2129 (izvor: Arhiva projekta Brodolom kod Gnalića - ogledalo renesansnog svijeta)

Fig. 38 Fragment of window pane with decoration made without central rosette, GN.2015.2129 (source: Archive of the Shipwreck near Gnalić project - a mirror of the Renaissance world; drawing by: Z. Bakić)

Morosini zamolio Senat Mletačke Republike da u Carigrad pošalje 5000 prozorskih stakala (mlet. rui) (sl. 40), upućena je u Veneciju 24. svibnja 1583. godine. ${ }^{32}$ Stakla je za obnovu netom izgorjele stare palače/harema sultana Murata III. naručio veliki vezir Sijavuš-paša, koji je na sebe preuzeo dio obnove oštećenoga zdanja. ways, around which the honeycomb decoration spreads. Only in one case was the decoration made without a central rosette (Fig. 38). In the future, it is necessary to pay more attention to decorated window panes, and to systematically analyse all variants of decorations.

Thanks to archival research ${ }^{29}$ which, following Gasparetto's discoveries, led to the final confirmation that the ship at the time of sinking belonged to da Gagliano family and was called Gagliana grossa, many documents about its construction, its dynamic life story, and the goods and people who were present on the ship during the last journey have been traced to this day. ${ }^{30}$ An encoded message by the bailo ${ }^{31}$ Giovanni Francesco Morosini, asking the Senate of the Venetian Republic to send 5,000 window panes (Ven. rui) to Constantinople (Fig. 40) was sent to Venice on May 24, 1583. ${ }^{32}$ Window panes for the reconstruction of the recently burned Old Palace/Harem of Sultan Murat III were ordered by the Grand Vizier Siyavuş Pasha, who took over part of the restoration of the damaged building.

It was not until September 16 of the same year that the Senate finally decided to comply with the Grand Vizier's wish, and send to Constantinople containers of window panes, which were loaded on the ship Gagliana grossa a week later, probably sealed with the doge's seal. We learn from the documents that the Senate issued an order to load three bales of "perfect" silk on the same ship as a gift for the Sultan's mother, Sultana Nurbanu, as well as a bale

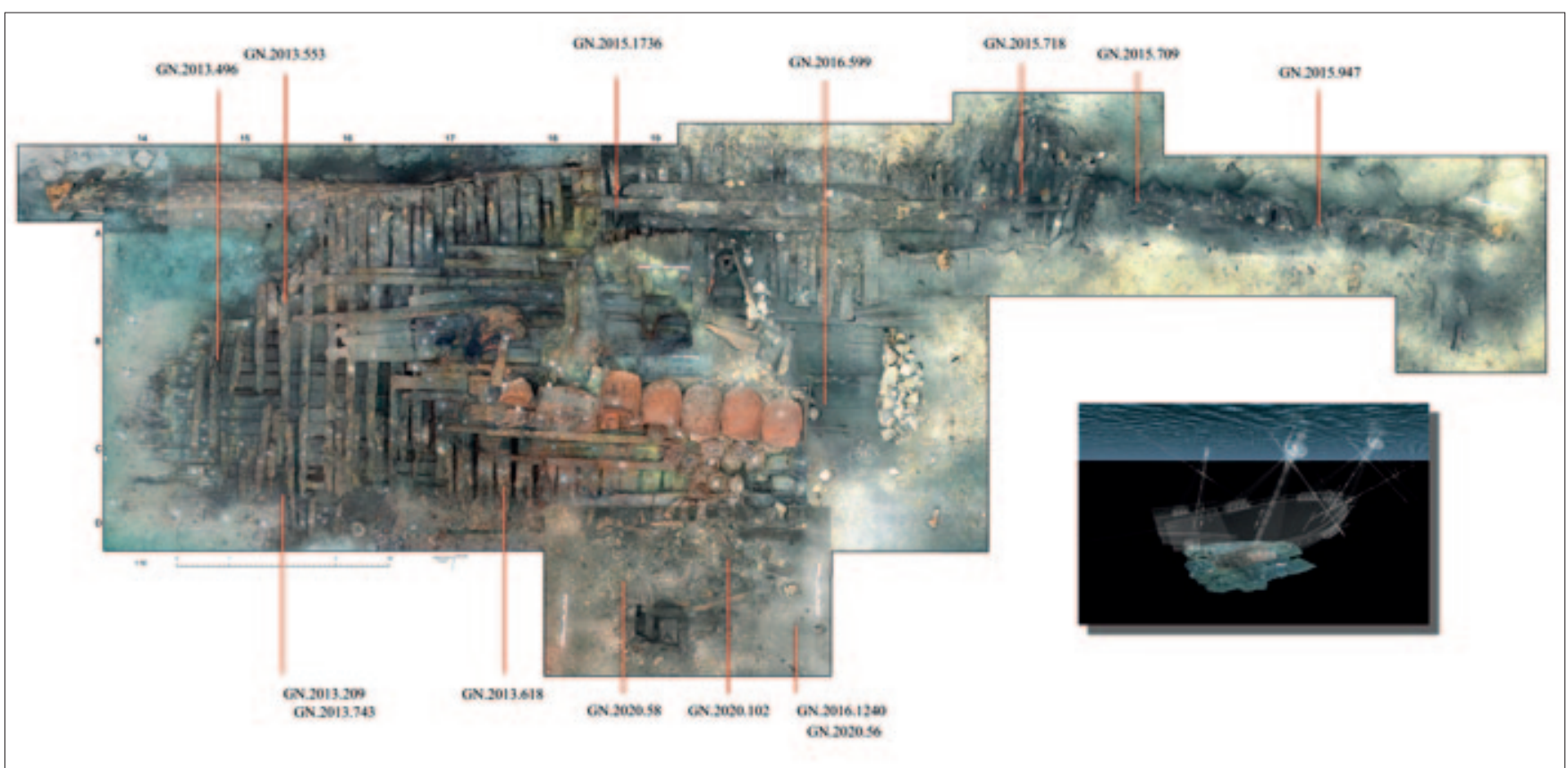

SI. 39 Mjesta pronalaska staklenih predmeta opisanih u poglavlju o novim nalazima, označena na ortogonalnom fotomozaiku nalazišta iz 2016. (izradila: I. Šelendić; podloga: K. Yamafune, R. Torres, S. Govorčin, D. Gorički)

Fig. 39 Locations of glass objects described in the chapter on new finds, marked on the orthogonal photomosaic of the site from 2016 (made by: I. Šelendić; base: K. Yamafune, R. Torres, S. Govorčin, D. Gorički)

Tek 16. rujna iste godine Senat je napokon odlučio udovoljiti želji velikog vezira i odaslati u Carigrad sanduke sa staklom koji su tjedan dana kasnije, vjerojatno zapečaće-

32 A.S.Ve, Senato, dispacci degli ambasciatori e residenti, Costantinopoli, f. 17, $277 v-278 r$.
29 Research at the State Archives in Venice was conducted by Mauro Bondioli and Mariangela Nicolardi.

30 The story is told in detail in Radić Rossi, Nicolardi 2019: 103-157.

31 Venetian ambassador in Constantinople.

32 A.S.Ve, Senato, dispacci degli ambasciatori e residenti, Costantinopoli, f. 17 $277 v-278 r$. 
ni duždevim pečatom, ukrcani na brod Gagliana grossa. Iz dokumenata saznajemo kako je Senat izdao nalog da se na isti brod ukrcaju i tri bale "savršene" svile kao poklon za sultanovu majku, sultaniju Nurbanu, kao i bala brokatela za četiri odore za Sijavuš-pašu. Tijekom istraživačke kampanje 2014. godine pronađen je olovni pečat sultana Murata III. (sl. 41) kojim je zasigurno bila zapečaćena državna roba, a možda upravo jedan od sanduka s prozorskim staklom.

Osim stakala ukrcanih po nalogu Senata, na brodu se, kao što je rečeno, nalazila i velika količina stakala za ogledala te brojno stakleno posuđe. lako za sada nemamo podataka tko je i zašto ukrcao staklene predmete, vrlo je vjerojatno da su bili namijenjeni carigradskome tržištu. Iz arhivskih dokumenata poznata su nam imena trgovaca koji su svoju robu ukrcali na brod Gagliana grossa, ali nam se u većini slučajeva nisu očuvali podaci o kakvoj je robi riječ.

Tijekom ranijih istraživanja ostaci broda interpretirani su kao brodsko dno okrenuto pramčanim dijelom prema zapadu, a krmenim prema istoku (sl. 39). Novo sustavno istraživanje pokazalo je, međutim, kako nije riječ o brodskome dnu već o desnome boku broda koji je legao na morsko dno pramcem prema istoku, a krmom prema zapadu. Sukladno tome, brodska se kobilica nalazi na sjevernome rubu nalazišta dok se desni bok, mjestimično do razine prve, a možda i druge palube, očuvao u smjeru juga, tj. dubljega dijela nalazišta. of brocatelle for four uniforms of Siyavuş Pasha. During a research campaign in 2014, the lead seal of Sultan Murat III was found (Fig. 41), by which the state goods were certainly sealed, and perhaps one of the boxes with window panes.

In addition to the window panes loaded by order of the Senate, the ship, as already said, also contained a large amount of mirror glasses and numerous glassware. Although we do not yet have archival data on the glass objects, it is very likely that they were intended for the Constantinople market. We know from archival documents the names of the merchants who loaded their goods on the ship Gagliana grossa, but in most cases the information about the goods in question was not preserved.

During earlier research, the remains of the ship were interpreted as the ship's bottom with the bow facing west, and the stern facing east (Fig. 39). New systematic research has shown, however, that the hull remains do not represent the ship's bottom but the starboard side of the ship that lies on the seabed with the bow facing east and the stern facing west. Accordingly, the ship's keel is located on the northern edge of the site, while the starboard side, in some places preserved up to the level of the first and possibly the second deck, has been preserved in the southern direction, i.e. the deeper part of the site.

Although flat glass is found scattered throughout the site as a result of cargo dispersal due to deterioration of transport containers, flat glass has been preserved in rows in squares D 19/20 and E 19/20, which coincide with the space

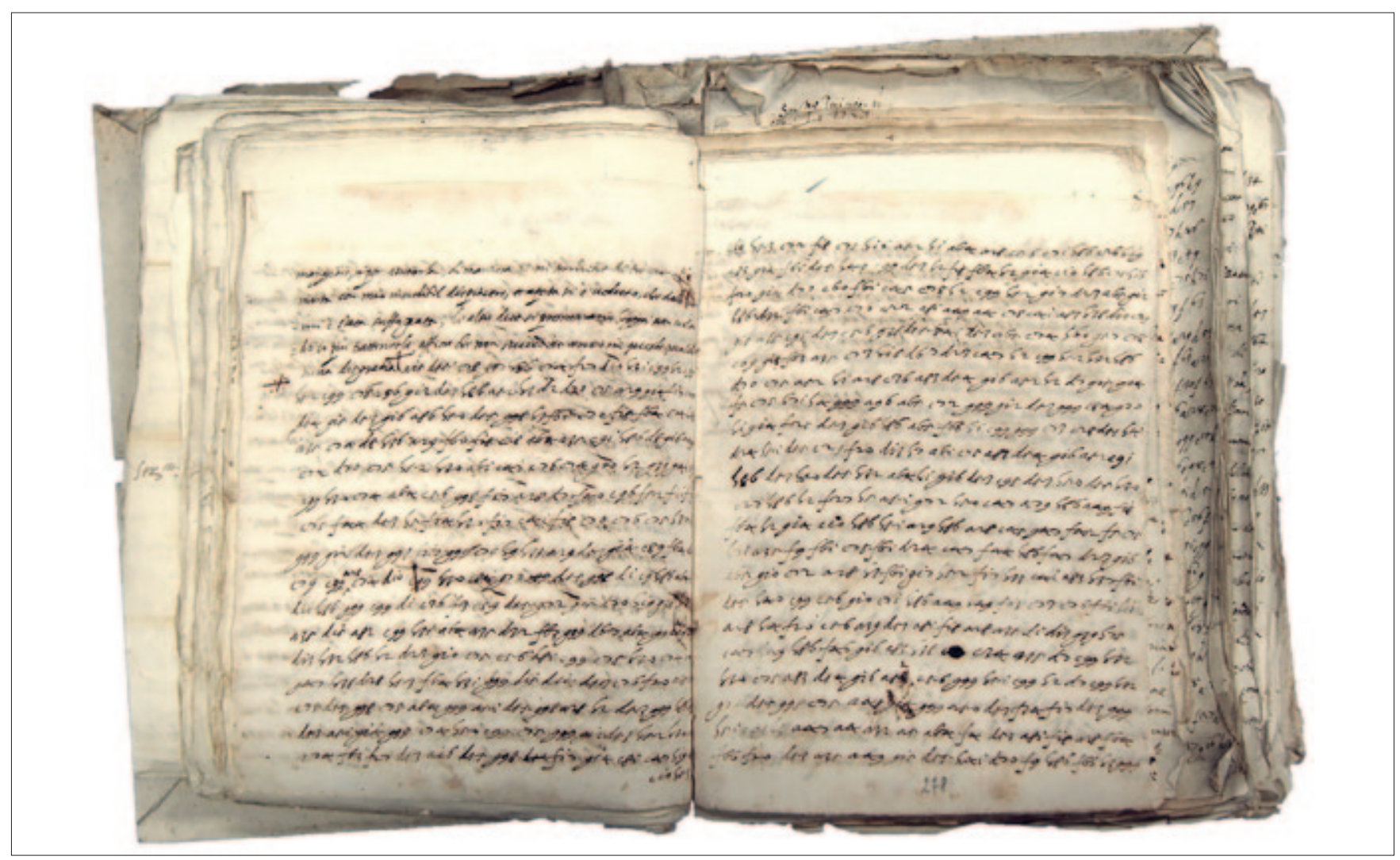

SI. 40 Šifrirani dokument kojim mletački bailo Giovanni Francesco Morosini izviješćuje Senat o narudžbi 5000 prozorskih stakala za sultana Murata III. (A.S.Ve, Senato, Dispacci degli ambasciatori e residenti, Constantinopoli, f. 17, cc. 277v-278r)

Fig. 40 An encrypted document by which the Venetian bailo Giovanni Francesco Morosini informs the Senate of the order of 5,000 window panes for Sultan Murat III (A.S.Ve, Senate, Dispatches of Ambassadors and Residents, Constantinople, f. 17, cc. 277v-278r) 


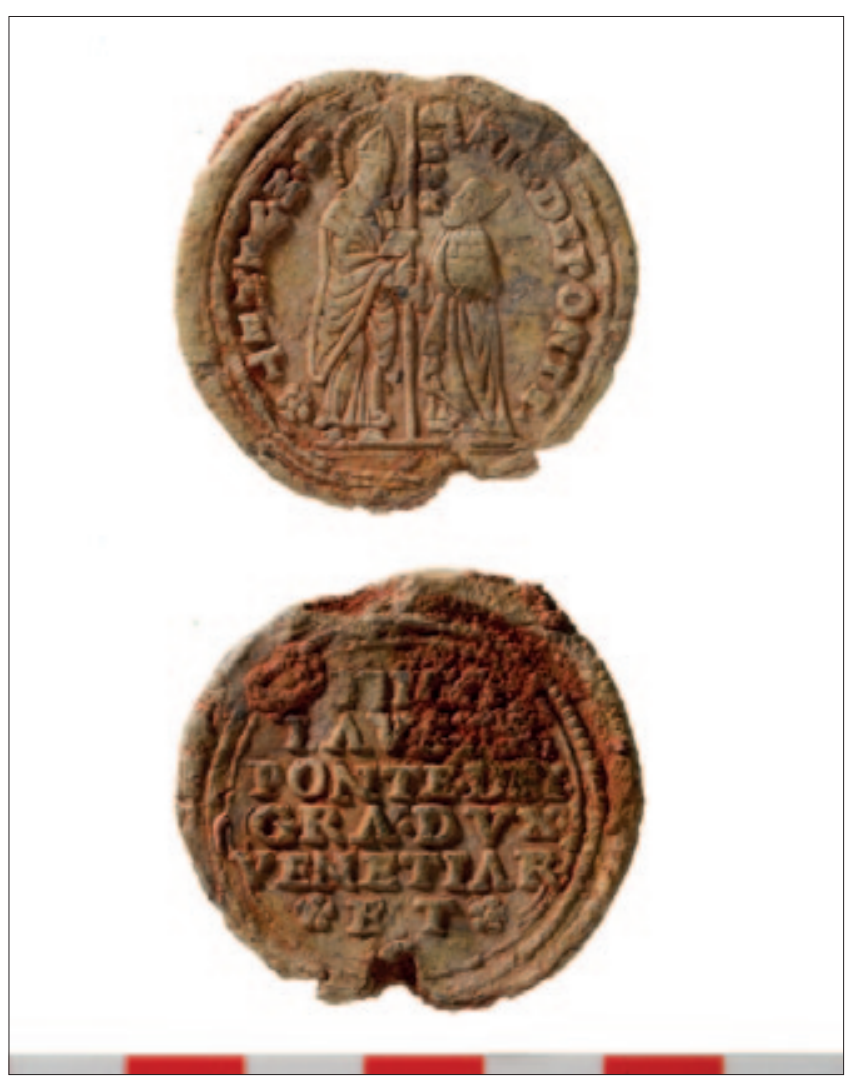

SI. 41 Olovni pečat mletačkoga dužda (Nicolò da Ponte, 1578. 1585.) (snimio: S. Govorčin)

Fig. 41 Lead seal of the Venetian doge (Nicolò da Ponte, 1578-1585) (photo by: S. Govorčin)

lako se ravno staklo pronalazi širom čitavoga nalazišta kao posljedica rasipanja tereta uslijed propadanja transportne ambalaže i brodske konstrukcije, ravno staklo očuvalo se u nizovima u kvadratima D 19/20 i E 19/20 koji se poklapaju s prostorom nad razinom prve palube. Stoga je vrlo vjerojatno da su sanduci i ostali ambalažni recipijenti s ravnim staklenim materijalom bili ukrcani na prvu palubu, povrh teškoga tereta sirovina i poluproizvoda, koji je bio smješten u najnižem dijelu potpalublja. Uz njih se djelomično nalazilo i stakleno posuđe jer su primjerci staklenih predmeta raznih oblika pronađeni u istoj zoni.

Prozorsko staklo i staklo za ogledala u ogromnim se količinama pronalazi, kao što je rečeno, na čitavome prostoru brodoloma, pa je tijekom novih istraživanja daleko nadmašen raniji omjer šupljega i ravnoga stakla. Irena Lazar i Hugh Willmott procijenili su da je na stakleno posuđe i ambalažu otpadalo oko $75 \%$ brodskoga tereta, dok je ravno staklo bilo zastupljeno s 25\% (Lazar, Willmott 2006a: 25; Lazar 2015: 269). Dosadašnji nalazi, međutim, više ne podržavaju takve brojeve jer su u podmorju pronađene tisuće ulomaka ravnoga stakla, među kojima se povremeno pronalaze i čitavi primjerci.

Zahvaljujući novim spoznajama o položaju broda, moguće je interpretirati i tzv. 'zonu stakla' južno i jugozapadno od glavnoga dijela nalazišta za koju se nekada smatralo da je nastala zbog plutanja ambalaže ispunjene staklenim predmetima i njezinoga potonuća nešto dalje od mjesta brodoloma. ${ }^{33}$ Zbog potonuća broda na desni bok, a time i

33 Prema dosadašnjoj interpretaciji košare su tijekom brodoloma otplutale ili su bile namjerno izbačene kako bi se olakšao brod u opasnosti: Lazar, Willmott 2006a: 21-22, 73. above the level of the first deck. It is therefore very likely that the chests and other packaging recipients with flat glass material were loaded on the first deck, on top of a heavy load of raw materials and semi-finished products stowed in the lowest part of the hull. These heavy products were partly accompanied by glassware, as specimens of glass objects of various shapes have been found in the same zone.

Window panes and mirror glasses have been found in huge quantities in the entire area of the shipwreck, so the original ratio of hollow and flat glass has been revised. Irena Lazar and Hugh Willmott estimated that glassware and glass containers accounted for about $75 \%$ of the ship's cargo, while flat glass accounted for 25\% (Lazar, Willmott 2006a: 25; Lazar 2015: 269). The finds, however, no longer support such numbers, because thousands of fragments of flat glass have been found underwater, among which also the entire specimens are occasionally found.

Thanks to new knowledge about the position of the ship, it is possible to interpret the so-called 'glass zone' south and south-west of the main part of the site, which was once thought to have formed due to the floating of containers filled with glass objects, and their sinking a little further from the shipwreck site. ${ }^{33}$ Due to the sinking of the ship on the starboard side, and thus the orientation of its upper part to the south, glassware packed in baskets, and perhaps in other light containers, located probably above the second deck, drifted to the south, and glass finds were scattered on the seabed. In the future, ongoing research could result in further new discoveries regarding the typology of finds and their placement on the ship decks, and thus enrich our knowledge on the transport of glass products and the repertoire of shapes traded during the Late Renaissance.

\section{CONCLUSION}

The 1976 work of Astone Gasparetto and the 2006 monograph by Irena Lazar and Hugh Willmott, in which the glass finds from previous research of the Gnalić shipwreck site are systematically presented and researched, are truly commendable ventures that should be relied on in future work. In both cases, these are attempts to first systematize the huge amount of glass material that was found in the ship's cargo, with the aim of better understanding glassware production and trade that took place during the second half of the $16^{\text {th }}$ century.

The continuation of research has led to new insights into the ship's history, its presumed route, the composition of the ship's cargo, and the position of the shipwreck on the seabed. In addition, the repertoire of glass finds has been enriched with new forms of glass products whose existence was not previously known. As the research progresses, the picture of the site and its overall content changes from year to year, which inevitably clarifies and enriches our previous knowledge. Therefore, the work on the typology of glass

\footnotetext{
33 According to the current interpretation, the baskets floated away during the shipwreck, or were deliberately thrown out to relieve the ship in danger. Lazar, Willmott 2006a: 21-22, 73
} 
orijentacije njegovoga gornjeg dijela prema jugu, stakleno posuđe zapakirano u košare, a možda i u drugu lakšu ambalažu smještenu vjerojatno nad drugom palubom, odletjelo je nekoliko desetaka metara južnije, a stakleni nalazi rasuli su se po morskome dnu. Istraživanje koje još uvijek traje moglo bi u budućnosti rezultirati daljnjim novim otkrićima po pitanju tipologije nalaza i njihovoga smještaja na brodskim palubama te time obogatiti naše spoznaje o transportu staklenih proizvoda i repertoaru oblika kojima se trgovalo u vrijeme kasne renesanse.

\section{ZAKLJUČAK}

Rad Astonea Gasparetta iz 1976. i monografija Irene Lazar i Hugha Willmotta iz 2006. godine, u kojima su sistematizirani stakleni nalazi iz ranijih istraživanja brodoloma kod otočića Gnalića, uistinu su hvalevrijedni pothvati na koje se svakako valja osloniti u budućem radu. U oba slučaja riječ je o pokušajima prve sistematizacije ogromne staklene građe koja se u trenutku brodoloma zatekla u brodskome teretu, s ciljem boljega razumijevanja problematike proizvodnje staklenih predmeta i trgovine koja se odvijala tijekom druge polovice 16. stoljeća.

Obnovljena istraživanja dovela su do novih spoznaja o povijesti broda, njegovoj pretpostavljenoj ruti, sastavu brodskoga tereta te položaju brodske olupine na morskome dnu. Osim toga, repertoar staklenih nalaza obogaćen je novim oblicima staklenih proizvoda za čije se postojanje do sada nije znalo. Napredovanjem istraživanja iz godine u godinu mijenja se slika o nalazištu i njegovome sveukupnom sadržaju, što neminovno uzrokuje izmjene i dopune dosadašnjih spoznaja. Stoga je rad na tipologiji staklenih nalaza potrebno nastaviti kako bi se postojeća baza podataka neprekidno ažurirala, a započeti klasifikacijski rad nastavio sukladno rezultatima na terenu.

Jedan od sljedećih koraka u obradi staklenih predmeta pronađenih u teretu potonuloga broda svakako je povezivanje sa stručnjacima koji dobro poznaju mletačku proizvodnju toga doba kako bi se oblici posuđa i ostalih staklenih proizvoda, navedeni u arhivskim dokumentima, povezali s konkretnim arheološkim nalazima. Taj posao uspješno je započeo Astone Gasparetto, ali se od 1976. godine nije na njemu dalje radilo. Povezati terminologiju koja se u kasnorenesansnoj Veneciji koristila za imenovanje različitih oblika stakla s predmetima koji pripadaju istovremenome arheološkom kontekstu značilo bi značajno uznapredovati u radu na proučavanju staklenoga dijela tereta velikoga trgovačkog broda potonuloga kod otočića Gnalića. Stoga se nadamo da ćemo u budućnosti imati prilike posvetiti se i toj temi te da će staklenim predmetima iz bogate gnalićke zbirke biti pridijeljena njihova izvorna imena.

\section{KATALOG NOVIH STAKLENIH NALAZA}

Kat. br. 1 - čaša s jednostavno plosnatim nodusom na povišenoj nožici (sl. 16a-b)

Datacija i ishodište: kasno 16. stoljeće; Murano, Venecija;

Dimenzije: visina 5,9-6,3 cm;

Način izrade: čaška je izrađena slobodnim puhanjem, dok je nožica oblikovana pomoću staklene smjese u koju se nije upuhivalo. Staklo je dobre kvalitete s manjim vidljivim mjehurićima;

Boja: bezbojna;

Napomena: pronađena su tri primjerka čaša (GN finds needs to be continued, in order to maintain an accurate database and to continue the classification work based on the results in the field.

One of the next steps in processing glass objects found in the ship's cargo is to engage with experts who are well acquainted with the Venetian production of that time. It would certainly lead to connecting the shapes of vessels and other glass products listed in archival documents with specific archaeological finds. The work was successfully started by Astone Gasparetto, but has not been revisited since 1976. Connecting the Late Renaissance Venetian terminology for different forms of glassware with objects recovered from the contemporary archaeological context would be significant progress in studying the glass part of the cargo of the large merchant ship sunk near the islet of Gnalić. Therefore, we hope that in the future we will have the opportunity to dedicate ourselves to this topic, and that the glass objects from the rich Gnalić collection will be given their original names.

\section{CATALOGUE OF NEW GLASS FINDS}

Cat. no. 1 - Goblet with a heightened stem with plain flattened knob (Fig. 16a-b)

Dating and origin: late $16^{\text {th }}$ century; Murano, Venice;

Dimensions: height 5.9-6.3 cm;

Method of production: The bowl is made by free blowing, while the foot is shaped using a not blown glass paste. The glass is of good quality, with smaller bubbles;

Colour: colourless;

Note: Three fragments of goblets were found (GN 2012.1141, GN 2012.1146, GN 2012.1152), of which the stem was completely preserved, while the bowl and the foot were preserved in fragments;

\section{Location: G2-G4.}

\section{Cat. no. 2 - Goblet with plain small stem (Fig.} 17a-b)

Dating and origin: late $16^{\text {th }}$ century; Murano, Venice;

Dimensions: height $5.9 \mathrm{~cm}$;

Method of production: The bowl is made by free blowing, while the foot is shaped using a not blown glass paste. The glass is of good quality, with smaller bubbles;

Colour: colourless;

Note: One goblet was found (GN 2012.1151), of which the stem was completely preserved, while the bowl and the foot were preserved in fragments;

Location: G2-G4.

\section{Cat. no. 3 - Goblet with lion mask stem and deco-} rated octagonal bowl (Fig. 18a-b)

Dating and origin: late $16^{\text {th }}$ century; Murano, Venice;

Dimensions: height $9.2 \mathrm{~cm}$, base diameter $7.3 \mathrm{~cm}$;

Method of production: The foot is made by blowing in a mould. The goblet, which has not been entirely preserved, is made by free blowing. It is octagonal, and is decorated with three horizontal white trails and a wavy glass trail at 
2012.1141, GN 2012.1146, GN 2012.1152) od kojih se u cijelosti očuvala nožica, dok su se čaška i podnožje očuvali u fragmentima;

Položaj nalaza: G2-G4.

Kat. br. 2 - čaša s jednostavnom malom nožicom

(sl. 17a-b)

Datacija i ishodište: kasno 16. stoljeće; Murano, Venecija;

Dimenzije: visina 5,9 cm;

Način izrade: čaška je izrađena slobodnim puhanjem, dok je nožica oblikovan pomoću staklene smjese u koju se nije upuhivalo. Staklo je dobre kvalitete s manjim vidljivim mjehurićima;

Boja: bezbojna;

Napomena: pronađen je jedan primjerak čaše (GN 2012.1151) od koje se u cijelosti očuvala nožica, dok su se čaška i podnožje očuvali u fragmentima;

Položaj nalaza: G2-G4.

Kat. br. 3 - čaša s nodusom u obliku lavlje glave na nožici i osmerokutnom dekoriranom čaškom (sl.

18a-b)

Datacija i ishodište: kasno 16. stoljeće; Murano, Venecija;

Dimenzije: visina 9,2 cm, promjer podnožja 7,3 cm;

Način izrade: nožica je izrađena puhanjem u kalupu. Čaška koja se nije sačuvala u cijelosti izrađena je slobodnim puhanjem, osmerokutna je, a dekorirana je s tri horizontalne bijele niti i valovitom staklenom trakom u donjem dijelu. Staklo je vrlo dobre kvalitete s vidljivim manjim mjehurićima;

Boja: zelena;

Napomena: pronađen je jedan primjerak čaše (GN 2012.1149). Podnožje i nožica očuvali su se u cijelosti, dok je čaška lakše oštećena;

Položaj nalaza: G2-G4.

Kat. br. 4 - dekorirana čaša s nodusom u obliku lavlje glave na nožici i kružnom dekoriranom čaškom (sl. 19a-b)

Datacija i ishodište: kasno 16. stoljeće; Murano, Venecija; Dimenzije: visina 8,8-9,6 cm, promjer podnožja 6,2 cm; Način izrade: nožica je izrađena puhanjem u kalupu. Čaška koja se nije sačuvala u cijelosti izrađena je slobodnim puhanjem i dekorirana je s tri horizontalne bijele niti i valovitom staklenom trakom u donjem dijelu. Staklo je dobre kvalitete s vidljivim mjehurićima;

Boja: siva;

Napomena: pronađena su tri primjerka čaša (GN 2012.1140, GN 2012.1144, GN 2012.1150). Podnožje i nožica očuvali su se u cijelosti, dok je čaška lakše oštećena;

Položaj nalaza: G2-G4.

Kat. br. 5 - dekorirani poklopac (sl. 21a-b)

Datacija i ishodište: kasno 16. stoljeće; Murano, Venecija;

Dimenzije: visina $2 \mathrm{~cm}$, promjer otvora $5 \mathrm{~cm}$;

Način izrade: poklopac je izrađen slobodnim puhanjem; njegovo oplošje ukrašeno je motivima listova izvedenih tehnikom graviranja dijamantnom iglom. Staklo je srednje kvalitete s vidljivim mjehurićima;

Boja: bezbojna;

Napomena: stakleni predmet nije očuvan u cijelosti (GN 2012.209); oštećen je na vrhu prihvata;

Položaj nalaza: C16. the bottom. The glass is of very good quality, with smaller bubbles;

Colour: green;

Note: One goblet was found (GN 2012.1149). The foot and stem are preserved in their entirety, while the bowl is slightly damaged;

Location: G2-G4.

Cat. no. 4 - Goblet with lion mask stem and round decorated bowl (Fig. 19a-b)

Dating and origin: late $16^{\text {th }}$ century; Murano, Venice; Dimensions: height 8.8-9.6 cm, base diameter $6.2 \mathrm{~cm}$;

Method of production: The foot is made by blowing in a mould. The bowl, which has not been entirely preserved, is made by free blowing and is decorated with three horizontal white trails and a wavy glass trail at the bottom. The glass is of good quality, with smaller bubbles;

Colour: grey

Note: Three goblets were found (GN 2012.1140, GN 2012.1144, GN 2012.1150). The foot and stem are entirely preserved, while the bowl is slightly damaged;

Location: G2-G4.

\section{Cat. no. 5 - Decorated lid (Fig. 21a-b)}

Dating and origin: late $16^{\text {th }}$ century; Murano, Venice; Dimensions: height $2 \mathrm{~cm}$, diameter of the opening $5 \mathrm{~cm}$;

Method of production: The lid is made by free blowing; its surface is decorated with leaf motifs made with the diamond needle engraving technique. The glass is of medium quality, with bubbles;

Colour: colourless;

Note: The glass object has not been entirely preserved (GN 2012.209); it is damaged at the top;

Location: C16.

Cat. no. 6 - Decorated long necked bottle with funnel-mouth rim (Fig. 22a-b)

Dating and origin: late $16^{\text {th }}$ century; Murano, Venice;

Dimensions: neck height $6.2 \mathrm{~cm}$, diameter of the opening $7.5 \mathrm{~cm}$;

Method of production: The neck of the bottle is made by free blowing and the filigree technique. The glass is of good quality, with smaller bubbles;

Colour: colourless;

Note: One piece of a bottle neck was found (GN 2015.718), decorated with a filigree technique. The trails are transparent, and not white as in common practice. Bottles with this type of neck are not entirely preserved;

Location: Z23.

Cat. no. 7 - Long necked bottle with opaque white trails (Fig. 23a-b)

Dating and origin: late $16^{\text {th }}$ century; Murano, Venice;

Dimensions: neck height $26 \mathrm{~cm}$, diameter of the opening $4.5 \mathrm{~cm}$;

Method of production: The neck of the bottle is made by free blowing technique and is decorated with the filigree 
Kat. br. 6 - ukrašena boca s dugim vratom i obo-

dom u obliku lijevka (sl. 22a-b)

Datacija i ishodište: kasno 16. stoljeće; Murano, Venecija;

Dimenzije: visina vrata $6,2 \mathrm{~cm}$, promjer otvora $7,5 \mathrm{~cm}$;

Način izrade: vrat boce izrađen je tehnikom slobodnog puhanja i tehnikom filigrana. Staklo je dobre kvalitete s manjim mjehurićima;

Boja: bezbojna;

Napomena: pronađen je jedan primjer vrata boce (GN 2015.718) ukrašen tehnikom filigrana na kojem su niti prozirne, a ne bijele kao što je uobičajena praksa. Boce s ovim tipom vrata nisu u cijelosti očuvane;

Položaj nalaza: Z23.

Kat. br. 7 - boca s dugim vratom dekorirana neprozirnim bijelim nitima (sl. 23a-b)

Datacija i ishodište: kasno 16. stoljeće; Murano, Venecija;

Dimenzije: visina vrata $26 \mathrm{~cm}$, promjer otvora $4,5 \mathrm{~cm}$;

Način izrade: vrat boce izrađen je tehnikom slobodnoga puhanja i ukrašen tehnikom filigrana. Staklo je dobre kvalitete $s$ većim mjehurićima;

Boja: bezbojna;

Napomena: pronađen je jedan primjer s dvije cjelovito očuvane valovite trake (GN 2013.553). Boce s ovim tipom vrata nisu u cijelosti očuvane;

Položaj nalaza: A15.

Kat. br. 8 - kruškolika staklena boca (sl. 24a-b)

Datacija i ishodište: kasno 16. stoljeće; Murano, Venecija;

Dimenzije: visina $7,7 \mathrm{~cm}$, promjer tijela $6,8 \mathrm{~cm}$;

Način izrade: vrat boce izrađen je tehnikom slobodnoga puhanja, a na vratu je očuvana valovita traka. Staklo je dobre kvalitete $s$ većim mjehurićima;

Boja: bezbojna;

Napomena: pronađen je jedan primjerak (GN 2020.102). Na dnu se nalazi nepravilan otvor, ali nije moguće zaključiti je li riječ o namjerno izrađenom otvoru ili oštećenju tijekom pomorske nesreće;

Položaj nalaza: D20.

Kat. br. 9 - podnožje velike zaobljene boce s profiliranim rubom (sl. 25a-b) tlo (?);

Datacija i ishodište: kasno 16. stoljeće; istočno podrije-

Dimenzije: promjer podnožja 7 i $8 \mathrm{~cm}$, visina podnožja 2,5 cm;

Način izrade: boca je izrađena tehnikom puhanja. Staklo je dobre kvalitete s manjim mjehurićima;

Boja: plava;

Napomena: novi promjeri staklenih podnožja (GN 2016.676, GN 2016.1240, GN 2016.1573, GN 2016.2234) pripadaju velikim zaobljenim bocama s profiliranim rubom (S24c). Nijedan primjerak nije se očuvao u cijelosti;

Položaj nalaza: /.

\section{Kat. br. 10 - podnožje (sl. 26a-b)}

Datacija i ishodište: kasno 16. stoljeće; Murano, Venecija?; Dimenzije: visina $3.7 \mathrm{~cm}$, promjer podnožja $3,7 \mathrm{~cm}$;

Način izrade: podnožje je izrađeno slobodnim puhanjem, a staklena smjesa na samom je dnu oblikovana kao završetak; technique. The glass is of good quality, with larger bubbles; Colour: colourless;

Note: One example was found, with two entirely preserved wavy trails (GN 2013.553). Bottles with this type of neck are not entirely preserved;

Location: A15.

\section{Cat. no. 8 - Pear-shaped bottle (Fig. 24a-b)}

Dating and origin: late $16^{\text {th }}$ century; Murano, Venice; Dimensions: height $7.7 \mathrm{~cm}$, diameter of the body $6.8 \mathrm{~cm}$;

Method of production: The neck of the bottle is made by free blowing technique, and a wavy trail is preserved on the neck. The glass is of good quality, with larger bubbles;

Colour: colourless;

Note: One object was found (GN 2020.102). There is an irregular hole at the bottom. It is not possible to conclude whether it was a deliberately made opening or damage that happened during the maritime accident;

Location: D20.

\section{Cat. no. 9 - The base of a large spherical bottle} with stepped rim (Fig. 25a-b)

Dating and origin: late $16^{\text {th }}$ century; eastern origin (?);

Dimensions: base diameter 7 and $8 \mathrm{~cm}$, base height $2.5 \mathrm{~cm}$;

Method of production: The bottle is made by blowing technique. The glass is of good quality, with smaller bubbles;

Colour: blue;

Note: The bases of new diameters (GN 2016.676, GN 2016.1240, GN 2016.1573, GN 2016.2234) belong to large spherical bottles with a stepped rim (S24c). There are no entirely preserved objects;

Location: /.

\section{Cat. no. 10 - Base (Fig. 26a-b)}

Dating and origin: late $16^{\text {th }}$ century; Murano, Venice?;

Dimensions: height $3.7 \mathrm{~cm}$, base diameter $3.7 \mathrm{~cm}$;

Method of production: The base is made by free blowing, and the glass paste is shaped as a finish at the very bottom;

Colour: dark red;

Note: One partially preserved base was found (GN 2015.709);

Location: Z24.

\section{Cat. no. 11 - Coloured glass base (Fig. 27a-b)}

Dating and origin: late $16^{\text {th }}$ century; eastern origin?;

Dimensions: height $1.3 \mathrm{~cm}$, base diameter $4.5 \mathrm{~cm}$;

Method of production: The base is made of dark blue glass material in the chalcedony glass technique, with pieces of red glass inserted, which gave an uneven red overlay on the surface of the object. The glass is of good quality, with larger bubbles;

Colour: red;

Note: One partially preserved base was found (GN 2020.58); Location: D/E-18/19/20.

Cat. no. 12 - Decorated base (Fig. 28a-b)

Dating and origin: late $16^{\text {th }}$ century; Murano, Venice; 
Boja: tamno crvena;

Napomena: pronađen je jedan primjerak djelomično očuvanog podnožja (GN 2015.709);

Položaj nalaza: Z24.

Kat. br. 11 - podnožje od obojenog stakla (sl.

27a-b)

Datacija i ishodište: kasno 16. stoljeće; istočno podrijetlo?; Dimenzije: visina 1,3 cm, promjer podnožja 4,5 cm;

Način izrade: podnožje je izrađeno od zagasito plavoga stakla u tehnici kalcedonskoga stakla, s umetnutim komadićima stakla crvene boje, čime se dobio nejednak crveni preljev po površini predmeta. Staklo je dobre kvalitete s većim mjehurićima;

Boja: crvena;

Napomena: pronađen je jedan primjerak djelomično očuvanoga podnožja (GN 2020.58);

Položaj nalaza: D/E-18/19/20.

\section{Kat. br. 12 - ukrašeno podnožje (sl. 28a-b)}

Datacija i ishodište: kasno 16. stoljeće; Murano, Venecija; Dimenzije: visina $2 \mathrm{~cm}$, promjer otvora $5 \mathrm{~cm}$;

Način izrade: zadebljano prstenasto podnožje izrađeno je od plavoga stakla. Na dnu podnožja vidi se ukras izveden od plastično apliciranih kapljica. Šest kapljica raspoređeno je oko jedne središnje;

Boja: plava;

Napomena: otkriven je jedan primjerak podnožja (GN 2013.618);

Položaj nalaza: C18.

\section{Kat. br. 13 - staklena ručka (sl. 29a-b)}

Datacija i ishodište: kasno 16. stoljeće; Murano, Venecija; Dimenzije: dužina $15,4 \mathrm{~cm}$, širina $0,8 \mathrm{~cm}$;

Način izrade: staklena ručka izrađena je optičkim puhanjem u kalupu, s rebrastom dekoracijom i dodatnim uvijanjem;

Napomena: otkriven je jedan primjerak (GN 2020.56) prošupljenoga staklenog elementa koji je služio kao ručka nekog staklenoga predmeta;

Položaj nalaza: E20.

\section{Kat. br. 14 - malo okruglo dovršeno ogledalo (sl.}

\section{0a-b)}

Datacija i ishodište: kasno 16. stoljeće; Murano, Venecija; Dimenzije: promjer $3 \mathrm{~cm}$;

Način izrade: staklena masa dovršenih ogledala izlijevala se na glatku površinu kamena. Ohlađena masa bi se polirala i rezala sve do određene forme. Na hladan ravan komad stakla stavljao bi se sloj kositra koji je sa živom tvorio amalgam čime bi se stvarao tanak reflektirajući sloj. Staklo je vrlo dobre kvalitete s manjim mjehurićima;

Boja: bezbojna;

Napomena: do sada se smatralo da su dovršena ogledala prevožena u dvije veličine, ali novi predmet pokazuje da su postojale tri različite dimenzije okruglih dovršenih ogledala. Malo okruglo ogledalo (GN 2013.743) ima poliranu površinu i rubove rezane do željenoga oblika;

Položaj nalaza: C18.

Kat. br. 15 - ukrašeno prozorsko staklo s rozetom s osam latica (prva varijanta) (sl. 31-33)

Datacija i ishodište: kasno 16. stoljeće; Murano, Venecija; Dimenzije: debljina stakla $0,1 \mathrm{~cm}$, cjelovito prozorsko
Dimensions: height $2 \mathrm{~cm}$, diameter of the opening $5 \mathrm{~cm}$;

Method of production: The thickened ring base is made of blue glass. At the bottom of the base, a drop-like relief ornament is visible. Six drops are arranged around the central one;

Colour: blue;

Note: One base was discovered (GN 2013.618);

Location: C18.

\section{Cat. no. 13 - Glass handle (Fig. 29a-b)}

Dating and origin: late $16^{\text {th }}$ century; Murano, Venice;

Dimensions: length $15.4 \mathrm{~cm}$, width $0.8 \mathrm{~cm}$;

Method of production: The glass handle is made by optical blowing in a mould, with ribbed decoration and additional twisting;

Note: One hollow glass element that served as the handle of a glass object was discovered (GN 2020.56);

Location: E20.

\section{Cat. no. 14 - Small round finished mirror (Fig. 30a-b)}

Dating and origin: late $16^{\text {th }}$ century; Murano, Venice;

Dimensions: diameter $3 \mathrm{~cm}$;

Method of construction: The glass paste of the mirrors was poured on the smooth surface of the stone. The cooled paste would be polished and cut all the way to a certain shape. A layer of tin, which formed an amalgam with mercury, would be placed on a cold flat piece of glass, creating a thin reflective layer. The glass is of very good quality, with smaller bubbles;

Colour: colourless;

Note: Until recently, finished mirrors were considered to be transported in two sizes, but the new item shows that there were at least three different dimensions of round finished mirrors. A small round mirror (GN 2013.743) has a polished surface and edges cut to the desired shape;

Location: C18.

\section{Cat. no. 15 - Window pane decorated with rosette design, composed of eight petals (first variant) (Figs.} 31-33)

Dated and origin: late $16^{\text {th }}$ century; Murano, Venice;

Dimensions: glass thickness $1 \mathrm{~mm}$, diameter of the entirely preserved window pane $17.8 \mathrm{~cm}$;

Method of production: Window panes, with folded edges, are made by the technique of optical blowing in a mould, and are decorated with rosette design. The glass is of very good quality, with smaller bubbles;

Colour: colourless;

Note: One window pane decorated with rosette design made of eight petals is entirely preserved, while the other is fragmented (GN 2015.1359, GN 2015.1451);

Location: surface find.

Cat. no. 16 - Window pane decorated with rosette design, composed of seven petals (Fig. 34a-b)

Dating and origin: late $16^{\text {th }}$ century; Murano, Venice;

Dimensions: glass thickness $0.1 \mathrm{~cm}$; 
staklo promjera $17,8 \mathrm{~cm}$;

Način izrade: prozorska stakla rađena su u tehnici optičkoga puhanja u kalupu, s oplošjem dekoriranim rozetom. Rubovi stakla imaju šuplje prstenasto zadebljanje. Staklo je vrlo dobre kvalitete s manjim mjehurićima;

Boja: bezbojna;

Napomena: ukrašena prozorska stakla s osam latica očuvana su kao ulomak i kao cjeloviti primjerak (GN 2015.1359, GN 2015.1451);

Položaj nalaza: površinski nalaz.

\section{Kat. br. 16 - ukrašeno prozorsko staklo s rozetom} sa sedam latica (sl. 34a-b)

Datacija i ishodište: kasno 16. stoljeće; Murano, Venecija;

Dimenzije: debljina stakla 0,1 cm;

Način izrade: prozorska stakla rađena su u tehnici optičkoga puhanja u kalupu, s oplošjem dekoriranim rozetom. Rubovi stakla imaju šuplje prstenasto zadebljanje. Staklo je vrlo dobre kvalitete s manjim mjehurićima;

Boja: bezbojna;

Napomena: ukrašeno prozorsko staklo sa sedam latica očuvano je kao ulomak (GN 2016.599);

Položaj nalaza: B22.

Kat. br. 17 - ukrašeno prozorsko staklo s rozetom s osam latica (druga varijanta) (sl. 35a-b)

Datacija i ishodište: kasno 16. stoljeće; Murano, Venecija; Dimenzije: debljina stakla 0,1 cm;

Način izrade: prozorska stakla rađena su u tehnici optičkoga puhanja u kalupu, s oplošjem dekoriranim rozetom. Rubovi stakla imaju šuplje prstenasto zadebljanje. Staklo je vrlo dobre kvalitete s manjim mjehurićima;

Boja: bezbojna;

Napomena: ukrašeno prozorsko staklo s osam latica očuvano je u ulomcima (GN 2015.947, GN 2015.35, GN 2015.283, GN 2015.1818, GN 2016.304, GN 2016.816);

Položaj nalaza: Z26.

Kat. br. 18 - ukrašeno prozorsko staklo s rozetom s jedanaest latica (sl. 36a-b)

Datacija i ishodište: kasno 16. stoljeće; Murano, Venecija;

Dimenzije: debljina stakla 0,1 cm;

Način izrade: prozorska stakla rađena su u tehnici optičkoga puhanja u kalupu, s oplošjem dekoriranim rozetom. Rubovi stakla imaju šuplje prstenasto zadebljanje. Staklo je vrlo dobre kvalitete s manjim mjehurićima;

Boja: bezbojna;

Napomena: ukrašeno prozorsko staklo s jedanaest latica očuvano je u ulomcima (GN 2015.536, GN 2015.284, GN 2015.474, GN 2015.535, GN 2015.768, GN 2015.1736, GN 2015.2035);

Položaj nalaza: Z19.

Kat. br. 19 - ukrašeno prozorsko staklo s rozetom s petnaest latica (sl. $37 \mathrm{a}-\mathrm{b})$

Datacija i ishodište: kasno 16. stoljeće; Murano, Venecija; Dimenzije: debljina stakla $0,1 \mathrm{~cm}$;

Način izrade: prozorska stakla rađena su u tehnici optičkoga puhanja u kalupu, s oplošjem dekoriranim rozetom. Rubovi stakla imaju šuplje prstenasto zadebljanje. Staklo je vrlo dobre kvalitete s manjim mjehurićima;

Boja: bezbojna;
Method of production: The window pane, with folded edge, is made by the technique of optical blowing into a mould, and is decorated with rosette design. The glass is of very good quality, with smaller bubbles;

Colour: colourless;

Note: The window pane decorated with rosette design composed of seven petals is preserved in fragment (GN 2016.599);

Location: B22.

Cat. no. 17 - Window pane decorated with rosette design, composed of eight petals (second variant)

(Fig. 35a-b)

Dating and origin: late $16^{\text {th }}$ century; Murano, Venice;

Dimensions: glass thickness $0.1 \mathrm{~cm}$;

Method of production: Window panes, with folded edges, are made by the technique of optical blowing into a mould, and are decorated with rosette design. The glass is of very good quality, with smaller bubbles;

Colour: colourless;

Note: Window panes decorated with rosette design composed of eight petals are preserved in fragments (GN 2015.947, GN 2015.35, GN 2015.283, GN 2015.1818, GN 2016.304, GN 2016.816);

Location: Z26.

Cat. no. 18 - Window glass decorated with rosette design, composed of eleven petals (Fig. 36a-b)

Dated and origin: late $16^{\text {th }}$ century; Murano, Venice;

Dimensions: glass thickness $0.1 \mathrm{~cm}$;

Method of production: Window panes, with folded edges, are made by the technique of optical blowing into a mould, and are decorated with rosette design. The glass is of very good quality, with smaller bubbles;

Colour: colourless;

Note: Window panes decorated with rosette design composed of eleven petals are preserved in fragments (GN 2015.536, GN 2015.284, GN 2015.474, GN 2015.535, GN 2015.768, GN 2015.1736, GN 2015.2035);

Location: Z19.

Cat. no. 19 - Window pane decorated with rosette design, composed of fifteen petals (Fig. 37a-b)

Dated and origin: late $16^{\text {th }}$ century; Murano, Venice;

Dimensions: glass thickness $0.1 \mathrm{~cm}$;

Method of production: Window panes, with folded edges, are made by the technique of optical blowing into a mould, and are decorated with rosette design. The glass is of very good quality, with smaller bubbles;

Colour: colourless;

Note: Window panes decorated with rosette design composed of fifteen petals are preserved in fragments (GN 2013.496, GN 2015.979);

Location: B15.

Cat. no. 20 - Decorated window pane without central rosette design (Fig. 38)

Dating and origin: late $16^{\text {th }}$ century; Murano, Venice;

Dimensions: glass thickness $0.1 \mathrm{~cm}$; 
Napomena: ukrašeno prozorsko staklo s petnaest latica očuvano je u ulomcima (GN 2013.496, GN 2015.979);

Položaj nalaza: B15.

Kat. br. 20 - Ukrašeno prozorsko staklo bez ukrasa središnje rozete (sl. 38$)$

Datacija i ishodište: kraj 16. stoljeća; Murano, Venecija; Dimenzije: debljina stakla 0,1 cm;

Način izrade: Prozorska stakla rađena su u tehnici optičkoga puhanja u kalupu, a ukrašena su motivom u obliku kapljica bez središnje rozete. Staklo je lošije kvalitete, s većim mjehurićima;

Boja: bezbojna;

Napomena: prozorska stakla sačuvana su u ulomcima (GN 2013.496, GN 2015.979);

Mjesto: površinski nalaz.
Method of production: Window panes are made by the technique of optical blowing into a mould, and are decorated with a drop-like motif without a central rosette. The glass is of poorer quality, with larger bubbles;

Colour: colourless;

Note: Window panes are preserved in fragments (GN 2013.496, GN 2015.979);

Location: surface find.
Prijevod / Translation Irena Radić Rossi

Lektura / Proofreading

Marko Maras 


\section{INTERNETSKI IZVORI / INTERNET SOURCES}

Bonhams on-line catalogue, Fine Glass, including the Overduin Collection, 21 May 2014, Lot 4: A large façon de Venise goblet, late 16th or early 17th century http://www.bonhams.com/auctions/22021/lot $/ 4 /$ ?category $=$ list\&length $=100 \&$ page $=1$ (05. 06. 2018.)

The British Museum - Čaša na nožici koju je izradio Giacomo (Jacopo) Verzelini, https://www.britishmuseum.org/collection/ object/H_1895-0603-17; http://www.britishmuseum.org/research/collection_online/collection_object_details/collection_image_gallery.aspx?partid $=1$ \&assetid $=32723001$ \&objectid $=28986$ (04. 06. 2018.)

Corning Museum of Glass, http://www.cmog.org/glass-dictionary/calcedonio (04. 06. 2018.)

Corning museum of Glass - Cjelovita čaša na nozi s poklopcem, https:// www.cmog.org/artwork/covered-goblet-vasenpokal (04. 06. 2018.)
Corning museum of Glass - Čaša na nožici koju je izradio Giacomo (Jacopo) Verzelini, http://www.cmog.org/artwork/goblet-236 (04. 06. 2018.)

Corning Museum of Glass - Pladanj na nozi, oko 1550.-1600., http:// www.cmog.org/artwork/drinking-tazza?image $=0$ (04. 06. 2018.)

Corning Museum of Glass - Glass Dictionary, tazza, pladanj na nozi, http://www.cmog.org/glass-dictionary/tazza (04. 06. 2018.)

Hrvatska enciklopedija, Leksikografski zavod Miroslav Krleža, http:// www.enciklopedija.hr/natuknica.aspx?id=57714 (03. 06. 2018.)

Rijksmuseum - Pladanj na nozi, oko 1550.-1650., https://www.rijksmuseum.nl/en/collection/BK-NM-774 (04. 06. 2018.)

Victoria and Albert Museum - Pladanj na nozi, 1550.-1600., http://collections.vam.ac.uk/item/O1513/tazza/ (04. 06. 2018.)

Web Gallery of Art - Posljednja večera / Last Supper (1476.) https://www. wga.hu/html_m/g/ghirland/domenico/4lastsup/index.html

\section{LITERATURA / BIBLIOGRAPHY}

Božulić, G. 2003, Teret potopljenog broda iz XVI. stoljeća, Vila Velebita: Časopis Hrvatske pomorske straže, Vol. 4-5, 61-66.

Brill, R. H. 1973, Analyses of some finds from the Gnalić wreck, Journal of Glass Studies, Vol. 15, 93-97.

Brusić, Z. 1996, Podmorska arheološka istraživanja kod otočića Gnalića na ulazu u Pašmanski kanal (Nastavak istraživanja 1996. g.), Zadar (neobjavljen rukopis arhivskog izvješća pohranjen u Konzervatorskom odjelu Ministarstva kulture RH u Zadru).

Davison, S. 2006, Conservation and Restoration of Glass, Second edition (reprint), Butterworth-Heinemann, Oxford.

Fadić, I. (ed.) 2011, Staklo iz morskih dubina. Brodolom kod Gnalića, katalog izložbe, Muzej antičkog stakla, Zadar.

Fadić, I., Perović, Š. 2017, Terminološki rječnik antičkog staklarstva, Muzej antičkog stakla, Zadar.

Filep, A. 2013, Prilog dokumentiranju zbirke „Teret potopljenog broda iz 16. stoljeća" Zavičajnog muzeja Biograd na Moru / A contribution to the documentation of the collection "Cargo of a $16^{\text {th }}$ century sunken ship" in the Biograd na Moru Heritage Museum, in: Gnalić. Blago potonulog broda iz 16. stoljeća / Gnalić. Treasure of a $16^{\text {th }} \mathrm{Centu}$ ry Sunken Ship, katalog izložbe / exhibition catalogue, Filep A., Jurdana E., Pandžić A. (eds.), Hrvatski povijesni muzej, Zagreb, 51-63.

Filep, A., Jurdana, E., Pandžić, A. (eds.) 2013, Gnalić. Blago potonulog broda iz 16. stoljeća / Gnalić. Treasure of a $16^{\text {th }}$ Century Sunken Ship, katalog izložbe / exhibition catalogue, Hrvatski povijesni muzej, Zagreb.

Foy, D. 2005, La suprématie du verre soufflé en cylindre: panneaux et vitraux du V $V^{\mathrm{e}}$ au IX $\mathrm{X}^{\mathrm{e}}$ siècle, in: De transparentes spéculations. Vitres de I'Antiquité et du Haut Moyen Age (Occident-Orient), Musée-Site Archéologique Départemental de Bavay - Conseil Général Département du Nord, Bavay, 59-64.

Gasparetto, A. 1973, The Gnalić wreck: Identification of the ship, Journal of Glass Studies, Vol. 15, 79-84.

Gasparetto, A. 1976, Vetri veneziani da un naufragio in Dalmazia e da documenti dell'ultimo cinquecento, Studi Venziani, Vol. XVII-XVIII (1975-1976), 411-466.

Gasparetto, A. 1977, Identifikacija potopljenog broda kod Gnalića, Zadarska revija, Vol. 3-4, 381-386.

Guštin, M., Gelichi, S., Spindler, K. (eds.) 2006, The heritage of the Serenissima: the presentation of the architectural and archaeological remains of the Venetian Republic, Proceedings of the international conference, Izola - Venezia, 4.-9. 11. 2005., Založba Annales, Koper.

Jackson, C. M. 2006, Compositional analysis of the Gnalić glass, in: I. Lazar, H. Willmott, The glass from the Gnalić wreck, Založba Annales, Koper, 87-95.
Jackson, C. M. 2009, Compositional case studies: Glass from the Gnalić Wreck, Quaderni Friulani di Archeologia, Vol. XIX, 137-145.

Jović Gazić, V. 2015, Gnalić u Gnaliću - Odsjaj stakla potopljena broda, katalog izložbe, Muzej antičkog stakla, Zadar.

Kelez, I. 1970, O sirovinama, Vrulje - Glasilo Narodnog muzeja u Zadru, Vol. $1,40-45$.

Lazar, I. 2010, I vetri del relitto di Gnalić, in: L'avventural del vetro dall rinascimento al Novecento tra Venezia e mondi lontani, katalog izložbe, Bova A. (ed.), Skira, Milano, 103-110.

Lazar, I. 2015, The glass from the Gnalić wreck and its glass cargo / Brodolom kod Gnalića i stakleni teret s potonulog broda, Vjesnik za arheologiju i historiju dalmatinsku, Vol. 108(1), 267-279.

Lazar, I., Willmott, H. 2006a, The Glass from the Gnalić Wreck, Založba Annales, Koper.

Lazar, I., Willmott, H. 2006b, The late $16^{\text {th }}$ century glass from the Gnalić wreck: an overview of forms, in: The heritage of the Serenissima: the presentation of the architectural and archaeological remains of the Venetian Republic, Proceedings of the international conference, Izola - Venezia, 4.-9. 11. 2005., Guštin M., Gelichi S., Spindler K. (eds.), Založba Annales, Koper, 99-104.

Magaš, D. 2006, Prirodno-geografska osnova otoka Pašmana, in: Toponimija otoka Pašmana, Skračić V. (ed.), Centar za Jadranska onomastička istraživanja Sveučilišta u Zadru, Zadar, 9-30.

Mileusnić, Z. (ed.) 2004, The Venetian Shipwreck at Gnalić. Biograd na Moru, Založba Annales, Koper.

Mileusnić, Z. 2006, The pottery from Gnalić wreck, in: The heritage of the Serenissima: the presentation of the architectural and archaeological remains of the Venetian Republic, Proceedings of the international conference, Izola - Venezia, 4.-9. 11. 2005., Guštin M., Gelichi S., Spindler K. (eds.), Založba Annales Koper, 104-107.

Munk, Z., Radulić, K. 1971, Blago s morskog dna. Izložba predmeta s potopljenog broda iz kraja 16. stoljeća, katalog izložbe, Muzej za umjetnost i obrt, Zagreb.

Petricioli, S. 1969, Blago s morskog dna. Izložba predmeta s potopljenog broda iz kraja 16. stoljeća, Narodni muzej Zadar, Zadar.

Petricioli, S. 1970, Staklo, in: Brod kod Gnalića - naše najbogatije hidroarheološko nalazište, Radulć K., Uranija V. (eds.), Vrulje: Glasilo Narodnog muzeja u Zadru 1, Narodni muzej Zadar, Zadar, 23-30.

Petricioli, S. 1971, Izložba „Blago s morskog dna” u Ljubljani i Zagrebu, Čovjek i prostor, Vol. 223.

Petricioli, S. 1973, The Gnalić wreck: The glass, Journal of Glass Studies, Vol. 15, 85-92.

Petricioli, S. 1974, Kulturno-historijsko značenje hidroarheološkog nalaza kod Gnalića, in: Zadarsko otočje, Zbornik radova Znanstvenog 
skupa, Iž 10. i 11. rujna 1971., Uranija V. (ed.), Narodni muzej Zadar, Zadar, 71-78.

Radić Rossi, I. 2012, Staklena Odiseja. Staklo u opremi i teretu broda / Glass Odyssey. Glass in the Ship's Equipment and Cargo, katalog izložbe / exhibition catalogue, Muzej antičkog stakla, Zadar.

Radić Rossi, I., Bondioli, M., Nicolardi, M., Brusić, Z., Čoralić, L., Vieira de Castro, F. 2013, Brodolom kod Gnalića - Ogledalo renesansne Europe / The Shipwreck of Gnalić - Mirror of Renaisance Europe, in: Gnalić. Blago potonulog broda iz 16. stoljeća / Gnalić. Treasure of a $16^{\text {th }}$ Century Sunken Ship, katalog izložbe / exhibition catalogue, Filep A., Jurdana E., Pandžić A. (eds.), Hrvatski povijesni muzej, Zagreb, 65-95.

Radić Rossi, I., Nicolardi, M. 2019. Brodolom kod Gnalića - ogledalo renesansnog svijeta, AGM, Zagreb.

Ratković Bukovčan, L. 2013, Transparentna ljepota. Staklo iz hrvatskih muzeja od XV. do XX. stoljeća, Muzej za umjetnost i obrt, Zagreb.
Skračić, V. (ed.) 2006, Toponimija otoka Pašmana, Centar za jadranska onomastička istraživanja Sveučilišta u Zadru, Zadar.

Topić, N. 2017, U traganju za renesansom. Staklo iz arheoloških istraživanja na dubrovačkom području / In search of Renaissance. Glass from the archaeological excataions in the Dubrovnik area, katalog izložbe, Dom Marina Držića, Dubrovnik.

Verità, M. 2014, Secret and innovations of Venetian glass between the $15^{\text {th }}$ and the $17^{\text {th }}$ centuries: raw materials, glass melting and artefacts, in: Study day on Venetian glass, Approximately 1600's, Barovier R., Tonini C. (eds.), atti CLXXII, Classe di scienze fisiche, matematiche e naturali 172/I, Istituto Veneto di Scienze Lettere ed Arti, Venezia, 53-68.

Willmott, H. 2002, Early post-medieval vessel glass in England c. 1500-1670, CBA Research Report 132, Council for British Archaeology, York.

Willmott, H. 2005, A History of English Glassmaking AD 43-1800, Tempus Publishing, Gloucestershire. 